\title{
Recharge at the Hanford Site: Status Report
}

\author{
G. W. Gee
}

November 1987

Prepared for the U.S. Department of Energy under Contract DE-AC06-76RLO 1830

Pacific Northwest Laboratory Operated for the U.S. Department of Energy by Battelle Memorial Institute 


\title{
DISCLAIMER
}

This report was prepared as an account of work sponsored by an agency of the United States Government. Neither the United States Government nor any agency thereof, nor Battelle Memorial Institute, nor any of their employees, makes any warranty, expressed or implied, or assumes any legal liability or responsibility for the accuracy, completeness, or usefulness of any information, apparatus, product, or process disclosed, or represents that its use would not infringe privately owned rights. Reference herein to any specific commercial product, process, or service by trade name, trademark, manufacturer, or otherwise, does not necessarily constitute or imply its endorsement, recommendation, or favoring by the United States Government of any agency thereof, or Battelle Memorial Institute. The views and opinions of authors expressed herein do not necessarly state or reflect those of the United States Government or any agency thereof, or Battelle Memorial Institute.

\author{
PACIFIC NORTHWEST LABORATORY \\ operated by \\ BATTELLE MEMORIAL INSTITUTE \\ for the \\ UNITED STATES DEPARTMENT OF ENERGY \\ under Contract DE-AC06-76RLO 1830
}

\begin{tabular}{|c|c|}
\hline \multicolumn{2}{|c|}{ Printed in the United States of America } \\
\hline \multicolumn{2}{|c|}{$\begin{array}{c}\text { Available from } \\
\text { National Technical Information Service } \\
\text { United States Department of Commerce } \\
5285 \text { Port Royal Road } \\
\text { Springfield, Virginia } 22161\end{array}$} \\
\hline \multicolumn{2}{|c|}{$\begin{array}{l}\text { NTIS Price Codes } \\
\text { Microfiche A01 }\end{array}$} \\
\hline \multicolumn{2}{|c|}{ Printed Copy } \\
\hline Pages & $\begin{array}{l}\text { Price } \\
\text { Codes }\end{array}$ \\
\hline $001-025$ & $\mathrm{~A} 02$ \\
\hline $026-050$ & A03 \\
\hline $051-075$ & A04 \\
\hline $076-100$ & A05 \\
\hline $101-125$ & A06 \\
\hline $126-150$ & $\mathrm{~A} 07$ \\
\hline $151-175$ & A08 \\
\hline $176-200$ & A09 \\
\hline $201-225$ & A010 \\
\hline $226-250$ & A011 \\
\hline $251-275$ & A012 \\
\hline $276-300$ & A013 \\
\hline
\end{tabular}


RECHARGE AT THE HANFORD SITE:

STATUS REPORT

G. W. Gee

November 1987

Prepared for

the U.S. Department of Energy

under Contract DE-ACO6-76RLO 1830

Pacific Northwest Laboratory Richland, Washington 99352 


\section{EXECUTIVE SUMMARY}

A variety of field programs designed to evaluate recharge and other water balance components (e.g., precipitation, infiltration, evaporation, and water storage changes) have been carried out at the Hanford Site since 1970. Data from these programs have indicated that a wide range of recharge rates can occur depending upon specific site conditions. Present evidence suggests that minimum recharge occurs where soils are fine-textured and surfaces are vegetated with deep-rooted plants. Maximum recharge occurs where coarse soils or gravels exist at the surface and soils are kept bare. Recharge can occur in areas where shallow-rooted plants dominate the surface, particularly where soils are coarse-textured. Recharge was estimated to be near zero during a 14-year period in a lysimeter located on the 200 Area plateau. In agreement with these results, moisture profiles from another site on the 200 Area plateau, where deep-rooted plants (sagebrush, hopsage, etc.) have been growing on fine soil, indicated that the soil has dried (likely as a result of water extraction by roots) to depths up to $8 \mathrm{~m}$; these results strongly suggest that recharge is less than $0.1 \mathrm{~cm} / \mathrm{yr}$ under these conditions. In contrast, data from drainage lysimeters located near the 300 Area indicate significant drainage has occurred during the past several years. Since 1985, 12 bare-surface lysimeters in the 300 Area have exhibited drainage rates of $10 \mathrm{~cm} / \mathrm{yr}$ or more while an adjacent vegetated (cheatgrass-covered) lysimeter drained at an average rate of about $6 \mathrm{~cm} / \mathrm{yr}$. Neutron probe data at a grass-covered field site near the 300 Area also suggest that water is draining below the root zone under conditions of coarse soil and shallow-rooted vegetation.

Recharge estimates have been made for the site using simulation models. A U.S. Geological Survey model that attempts to account for climate variability, soil storage parameters, and plant factors has calculated recharge values ranging from near zero to an average of about $1 \mathrm{~cm} / \mathrm{yr}$ for the Hanford Site. Other models such as the Morton or the Thornthwaite-Mather Model also tend to predict very low recharge rates. These estimates apparently do not account for site-specific soil conditions and plant cover types (e.g., bare soils or shallow-rooted plant cover); hence they do not predict observed high 
recharge rates (more than $50 \%$ of the total annual precipitation). Furthermore, none of the simplified codes that have been used to date have been calibrated specifically for Hanford Site conditions.

UNSAT-H, a deterministic model developed for the site, appears to be the best code available for estimating recharge on a site-specific basis. Verification of this code has been completed (Fayer, Gee and Jones 1986), and calibration of the code to site-specific data is under way. The continuation of field monitoring of soil and plant parameters under a range of variable climatic conditions is designed to provide model input data for code calibration purposes.

Lysimeters have provided the first direct evidence of recharge for the Hanford Site. However, no waste storage sites at Hanford have been directly monitored for recharge. In areas where gravels cover the surface, such as tank farms, much of the annual precipitation can be expected to drain through the gravel and be available for recharge. The significance of gravel cover over waste sites needs to be assessed. 


\section{ACKNOWLEDGMENTS}

This work was funded by the U.S. Department of Energy through the Westinghouse Hanford Waste Management Program Office. I acknowledge the efforts of Cheri Defigh-Price and Carol Geier of Westinghouse Hanford Company in supporting the publication of this work. I thank a host of Pacific Northwest Laboratory colleagues who have contributed to this document, from collecting and analyzing data to editing earlier drafts and providing moral support for this effort. Of particular mention are Owen Abbey, Janelle Downs, Mike Fayer, Paula Heller, Tim Jones, Randy Kirkham, and Steve Link. I also acknowledge the advice of Dr. Daniel Hillel, University of Massachusetts (visiting NORCUS Professor), who provided additional insight regarding methods to evaluate recharge under arid site conditions. Finally, I wish to thank Chris Morgan and the PNL Text Processing staff for timely and patient support in preparing this document. 
CONTENTS

EXECUTIVE SUMMARY ................... i i i

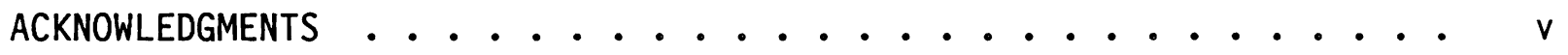

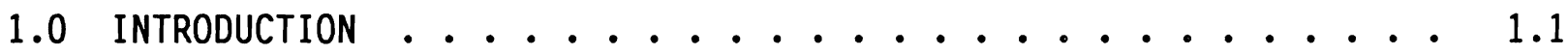

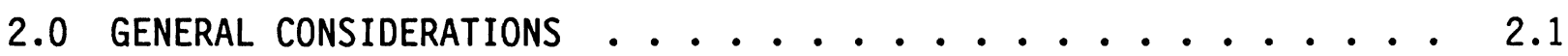

2.1 RECHARGE PROCESSES AT ARID SITES ................. 2.1

2.1.1 Recharge Workshop Summary . . . . . . . 2.2

2.2 RECHARGE PREDICTIONS AND MODELING . . . . . . . . . 2.4

2.2.1 Morton Model . . . . . . . . . 2.5

2.2.2 Thornthwaite-Mather Mode1 . . . . . . . 2.7

2.2 .3 USGS Model . . . . . . . . . . . 2.9

2.2 .4 UNSAT-H Model . . . . . . . . . . 2.10

3.0 LYSIMETER STUDIES . . . . . . . . . . . . . 3.1

3.1 THE 200 AREA DEEP LYSIMETER . . . . . . . . . 3.1

3.2 LYSIMETERS AT THE BWTF . . . . . . . . . . . . 3.5

3.3 OTHER 300 AREA LYSIMETERS . . . . . . . . . . 3.17

4.0 FIELD SITE DATA . . . . . . . . . . . . 4.1

4.1300 AREA GRASS SITE .................... 4.1

4.2 MCGEE RANCH SITE ...................... 4.3

5.0 OBSERVATIONS AND CONCLUSIONS ....................... 5.1

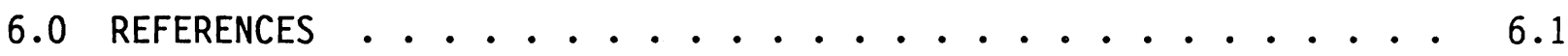

APPENDIX - PRECIPITATION AND DRAINAGE DATA FOR THE BURIED WASTE

TEST FACILITY AND HANFORD METEOROLOGICAL STATION

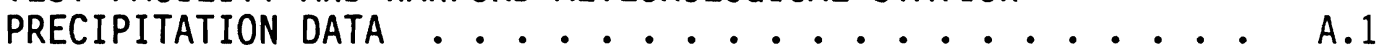




\section{FIGURES}

1.1 Location of Recharge Measurement Sites at the Hanford Site . . 1.2

3.1 Schematic Diagram of the 200-East Area Closed-Bottom

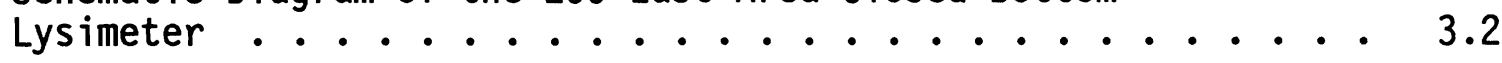

3.2 Schematic Diagram of the Lysimeters at the Buried Waste Test Facility Site in the 300 Area ................. 3.6

3.3 Drainage from South Caisson at the Buried Waste Test Facility Site Near the 300 Area, January 1984 Through June 1987 . . . 3.8

3.4 Comparison of the Buried Waste Test Facility Site and the Hanford Meteorological Station Precipitation, January 1979

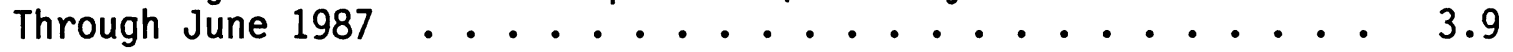

3.5 Water Storage Measured in the South Caisson Lysimeter Since 1980

3.6 Total Head Values for the South Caisson Lysimeter at the Buried Waste Test Facility Site Near the 300 Area . . . . . 3.12

3.7 Drainage From the North Weighing Lysimeter and South Weighing Lysimeter at the Buried Waste Test Facility Site Near the 300 Area . . . . . . . . . . . . . . 3.13

3.8 Comparison of Water Storage in the Buried Waste Test Facility Site Lysimeters, January 1984 Through June 1987 . . . . . . 3.14

4.1 Water Storage Changes at the Grass Site Near the 300 Area, January 1983 through June $1987 \ldots \ldots . \ldots . . \ldots 4.2$

5.1 Water Retention and Textural Properties of Three Hanford Site Soils................... 5.2 


\section{TABLES}

2.1 Recharge Estimates at the Hanford Site Using Climate Models . . 2.7

2.2 Simulations of Recharge at the Hanford Site ........ 2. 2.10

3.1 Water Content Data from the Closed-Bottom Lysimeter in the 200-East Area ................... 3.3

3.2 Surface Cover of South Weighing Lysimeter at the Buried Waste

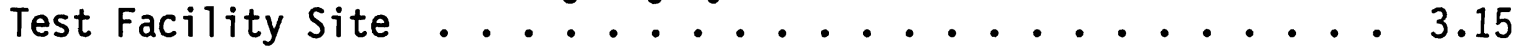

4.1 Water Potential Data from McGee Ranch Site, July 1986 . . . . 4.4

4.2 Water Content in Soil Material Taken from Boreholes at the McGee Ranch Site ............... . 4.5

A.1 Precipitation Data for the Buried Waste Test Facility Site

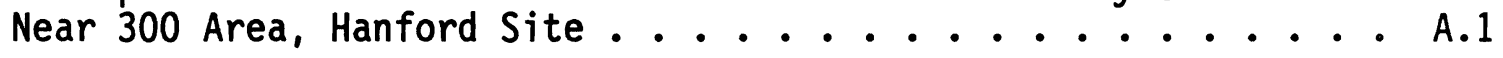

A.2 Precipitation Data for Hanford Meteorology Station . . . . A.12

A.3 Drainage from the South Caisson . . . . . . . . A.24

A.4 Drainage from the North Weighing Lysimeter . . . . . . A.27

A.5 Drainage from the South Weighing Lysimeter ........ A.28 


\subsection{INTRODUCTION}

Ground-water recharge is the process whereby the surplus of infiltration over evaporation (and transpiration) results in water draining through the vadose (unsaturated) zone to the water table, where it is added to the groundwater reservoir (unconfined aquifer). At Hanford, water from either artificial (recharge basins; i.e., ponds, cribs, trenches) or natural (rainfall, snowmelt) sources moves downward through a relatively thick (10 to $100 \mathrm{~m}$ or more) mantle of relatively coarse sediments to the water table, where in response to hydrostatic pressure-head differences it moves laterally toward and eventually intercepts the Columbia River. The amount of artificial recharge at Hanford is estimated to be $5.5 \times 107$ liters/day (DOE 1986). For a given seepage pond or crib, artificial recharge represents a major input to ground water on a unit-area basis (i.e., as much as several hundred times the 16-cm annual precipitation).

The exact quantity of natural recharge (i.e., from rainfall and snowmelt) in waste storage areas at Hanford is of considerable interest because it represents a mechanism for leaching of contaminants from waste materials and transporting them to the ground water. Locations and quantities of shallowburied wastes, particularly those located on the 200 Area plateau, have been documented (DOE 1986). Recharge (from natural sources) at these and other waste sites needs to be estimated as accurately as possible to predict the consequence of leaving the waste in place for time periods that may exceed thousands of years.

The purpose of the study that has produced the data documented by this report is to quantify natural recharge at Hanford, particulary for those conditions that exist at or near waste burial sites. Previous reports (Gee and Heller 1985; Gee and Jones 1985) have documented much of the background information that was used before 1985 to estimate recharge. This report provides continuity by describing work done since that time. Water balance data from four areas are provided. Two areas, the Buried Waste Test Facility (BWTF) and the 300 Area Grass Site, are located a few kilometers northwest of the 300 Area. The 200 Area deep lysimeter is located just south of the 200-East Area in the central part of the Hanford Site; the fourth area, the McGee Ranch 


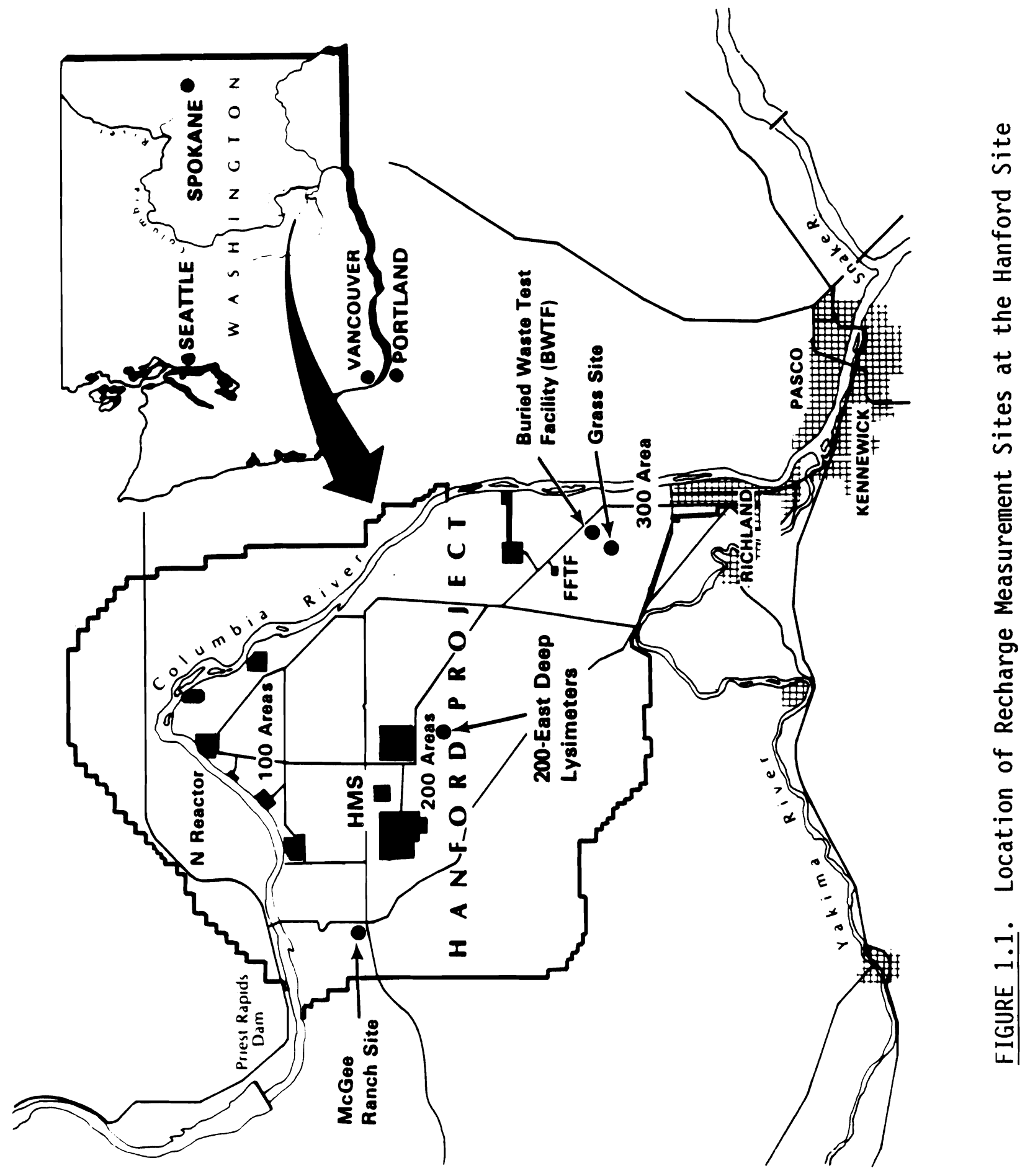


site, is located northwest of the 200 Areas (Figure 1.1). Water storage data from neutron probe or gravimetric water contents are provided for each site. For the BWTF site, drainage lysimeter and tensiometer data are also presented. These locations provide a relatively wide range of surface soil and plant cover conditions that exist at the Hanford Site and hence should provide a range of recharge rates.

In the following four sections of this report, Section 2.0 provides general considerations of recharge at arid sites, specific considerations regarding recharge at Hanford provided by a recent workshop on this topic, and previous modeling estimates of recharge at Hanford; Section 3.0 provides updated information on the lysimeters used at Hanford to estimate recharge and an analysis of water storage data from lysimeters in the 200 Area compared to measured drainage in the 300 Area; Section 4.0 provides comparisons of water balance data from the 300 Area Grass Site and the McGee Ranch, and a discussion of effects of plant cover and soil type on recharge; and Section 5.0 presents a summary and conclusions from observations of present recharge rates, and states implications for current and future waste management practices at Hanford. An appendix of key data is also provided. 


\subsection{GENERAL CONSIDERATIONS}

\subsection{RECHARGE PROCESSES AT ARID SITES}

Recharge at arid sites is generally low but for specific locations can vary from zero to a large fraction of the annual precipitation. Such variations have been observed at Hanford and will be described in subsequent sections.

Recharge depends on a variety of factors, including rainfall distribution and intensity, topographic and surface conditions, and soil texture and layering. Variation in precipitation input is a major contributor to the wide range of recharge that can occur. The temporal and spatial variability of precipitation at arid sites is difficult to quantify, and extreme events can have major consequences on recharge. In addition, the profound effect of precipitation on plant cover as well as on surface soil moisture and other physical features creates significant variations in water loss by evapotranspiration (ET), which can alter the recharge and other water balance components of the site. Recharge estimates thus require a thorough knowledge of the expected variations of the key factors (i.e., precipitation, soil type, and plant cover) and their interactions with the individual components of the site water balance. Utilizing models that do not account for these variations may be misleading and often underestimate the recharge that occurs.

Direct measurements of recharge at arid sites such as Hanford are difficult and often impossible; because water tables are deep and surface streams are ephemeral, discharge data are nonexistent. For arid sites one must rely on indirect measurements such as changes in water table depth, lysimeter drainage data, changes in water storage in a given soil profile, evapotranspiration (ET) measurements and subsequent calculations of water balance, thermal profile estimates, and tracer tests. All these methods are fraught with difficulty, but some are more useful than others, depending on the level of accuracy required and the use to which the recharge data will be applied.

Studies of waste management at arid sites often require very precise knowledge about the existence and extent of recharge. An external peer-reviewed Recharge Workshop that was held in 1985 has provided the focus for much of the recharge research conducted at Hanford during the past 2 years. A summary of that workshop is presented in this section. In subsequent sections, recharge 
predictions that have been made for Hanford, the type of data that have been required for these models, and their relative merits for use in waste management considerations for the site are discussed.

\subsubsection{Recharge Workshop Summary}

Key issues related to recharge at Hanford were reviewed in a "Recharge Workshop" held October 14-15, 1985, in Richland, Washington. A panel of five experts in hydrology, with specific interests in unsaturated water flow in porous media, were invited to review past work, to respond to specific questions, and to recommend directions for future work related to recharge at Hanford. The panel consisted of Dr. Gaylon S. Campbe11, Washington State University, Pullman, Washington; Dr. Daniel Hillel, University of Massachusetts, Amherst, Massachusetts; Dr. Arthur W. Warrick, University of Arizona, Tucson, Arizona; Dr. Edwin P. Weeks, U.S. Geological Survey, Denver, Colorado; and Dr. Stephen Whitaker, University of California, Davis, California. The panel prepared a report that was made available to the workshop participants from the U.S. Department of Energy (DOE), Pacific Northwest Laboratory (PNL), and Rockwell Hanford Operations personnel. Several key points made by the panel regarding recharge measurements are included here for background information and to provide a rationale for the ongoing work on Hanford Site recharge.

Excerpts from their comments on recharge follow:

Notwithstanding the general aridity of the climate at the Hanford Site and the absence of deep percolation in 'normal' years, it is entirely possible that some recharge of groundwater may indeed occur following episodes of unusually high precipitation. Such occurrences are particularly likely under topographic depressions where surface water might accumulate, in places underlain by very coarse and highly permeable deposits, and when the land is denuded of vegetation (as by fire, by overgrazing, or by mechanical clearing).

The amounts and timing of downward percolation from the soil toward the water-table are highly dependent on the vegetation and on the temporal distribution of precipitation. With deeprooted perennial vegetation, downward liquid fluxes may be almost balanced by upward distillation due to the geothermal temperature gradient. The net water flux may therefore be close to zero most of the time, and be either positive or negative part of the time. At the other extreme, unvegetated surfaces with pebble or cobble pavement will tend to retard evaporation and cause the accumulation within the soil of some 
$50 \%$ to $75 \%$ of the precipitation they receive. The eventual recharge under such surfaces may therefore amount to several centimeters per year.

As mentioned above, a key issue in determining long-term recharge is the occurrence of extreme rainfall or vegetation fluctuations. While deep-rooted vegetation may use nearly all of the available water in normal years, such vegetation will generally not increase water use sufficiently in extremely wet years to prevent the downward percolation of the excess of infiltration over evapotranspiration. The sandy and gravelly soils and subsoils of the Hanford area retain little water, so the amount draining out of the root zone is likely to find its way, sooner or later, to the water-table. Once water percolates below the root zone, significant upward movement in the liquid phase is unlikely. Fires which destroy perennial vegetation often result in the growth of shallow-rooted annuals, and consequently increase the likelihood that some water will move down beyond the depth to which soil moisture can be extracted by plants and returned to the atmosphere.

Knowing the magnitude of recharge is the key to calculating travel time in the event of a leakage or containment failure. The magnitude of recharge and the travel time are important not only in themselves, but also insofar as they influence the mechanisms and time periods for solute interactions. Diffusion, adsorption, reaction kinetics and flow rates must all be taken into account in assessing the transport of waterborne contaminants within the soil.

The panel was asked to specify what the annual recharge was at Hanford and to predict what it would be in 10,000 years. The panel did not answer these questions directly but indicated some of the difficulties in obtaining recharge estimates. They stated that evaluation of the downward percolation rates at Hanford is made particularly difficult by the following facts:

1. The recharge rates are of the same order of magnitude as the measurement errors of flux at the surface boundary (in some cases the recharge rates are smaller). Even though water movement below the root zone is slow, its cumulative amount cannot be neglected when projections extend over long periods.

2. The biological system is difficult to quantify. Root activity and plant growth impact the amount and timing of water uptake, and this in turn, influences the percolation rate. Effects such as range fires, nutrient interactions, or changes in the ecological system can become dominant at any particular time. 
3. Point measurements and observations are difficult to project over large areas. The effect of local depressions, on a scale of a few square meters, could dominate infiltration, as well as plant growth, evapotranspiration, and the moisture regime below the root zone. Subsurface strata are important in determining the flow pattern in the unsaturated zone. Of great interest is the possible existence of preferred paths, especially such that might connect the soil's surface zone directly to the water table.

4. The data base pertaining to precipitation is too short in duration for determining the likelihood of extreme events with confidence, and insufficient for extending to very long periods (say, beyond 50 to 100 years). Although at first glance the records from the early $1900^{\prime} s$ would appear to be sufficient for any conceivable purpose, on close examination a precise probability figure for a 100-year precipitation event, or a cluster of extreme events, cannot be defined. This is due to the extremely skewed rainfall variation from year to year. Significant recharge may well result from only a few years out of many (i.e., from unusual episodes). Long-term climatic trends are yet undiscernible, so future changes cannot be predicted.

The recharge workshop panel further recommended that a suite of measurements be made in subsequent years to better define the site characteristics that influence recharge. Their recommendations included: evaluation of soil hydraulic properties; measurements of plant cover type, rooting patterns, water use variations, and phenology; additional lysimeter tests that include comparisons of vegetated to bare surfaces and are designed to measure drainage as well as other water balance components; and tracer tests at hydrologically representative sites.

\subsection{RECHARGE PREDICTIONS AND MODELING}

Several studies have used numerical models to estimate recharge at Hanford. Some of these models have been relatively simplistic, relying on a few key climatic parameters such as humidity and precipitation, while others have been more complex, requiring an estimate of topography, soil type, and plant cover as well as climatic data. A brief review of these models and their application to the Hanford Site follows. 


\subsubsection{Morton Model}

Wallace (1978) used a model developed by Morton $(1975,1976)$ to estimate evapotranspiration for the Hanford Site and then calculated recharge from water balance considerations. The Morton model utilizes climatic data exclusively. It is based on the assumption that interactions between evaporating surfaces and overpassing air alter temperature and humidity of the air in a unique way. This results in a "feedback loop" which in turn modifies the surface evaporation. A complementary relationship between changes in potential and actual evapotranspiration is used to calculate the actual evapotranspiration. The potential evapotranspiration (PET) is defined as the computed water loss from the surface under a given climate (i.e., dependent on temperature, humidity, wind speed, radiation), assuming that the surface was a well-watered, short crop such as grass. The areal or actual evapotranspiration (AET) is defined as the surface water loss from an area so large that the effects of evapotranspiration on the temperature and humidity of the overpassing air are fully developed. Details of the equations used to calculate both PET and AET are provided by Wallace (1978).

The Morton model requires, as input, latitude, annual average atmospheric pressure, and weekly or monthly mean values of precipitation, air temperature, dew point temperature, and the ratio of the observed to the maximum possible sunshine duration for each time period. Data from the Hanford Meteorological Station provided long-term monthly averages for temperature, precipitation, relative humidity, dew point, sky cover, barometric pressure, wind speed, and solar radiation, which allowed Wallace to compare the Morton model with those of Penman (1948) and Thornthwaite and Mather (1955). The long-term records varied in length of time: from 1912 to 1970 for temperature and precipitation and from 1953 to 1970 for solar radiation.

Potential evapotranspiration (PET) was computed for all three methods. For the long-term (1912-1970) climate record, the computed PET values were 74.7, 79.5, and $139.2 \mathrm{~cm} / \mathrm{yr}$ for the Thornthwaite-Mather, Penman, and Morton methods, respectively. This compares with the long-term average precipitation value of $15.9 \mathrm{~cm} / \mathrm{yr}$. On the basis of the difference of precipitation and potential evapotranspiration alone, all three models would predict that there would not be recharge at Hanford. Calculations similar to these have been 
made for the Hanford Site in the past (ERDA 1975) and have led to erroneous assumptions about the potential for recharge. This method suggests that no recharge could ever occur at Hanford under present climate conditions. As discussed previously and pointed out by Thornthwaite and Mather (1955) and Morton (1975, 1976), actual evapotranspiration is generally just a small fraction of potential evapotranspiration for an arid site.

Actual evapotranspiration (AET) values were computed for the ThornthwaiteMather and the Morton models. By making the assumptions that no runoff occurs (which appears to be reasonable for most of the waste storage areas at Hanford) and that the annual storage changes are zero (that is, the initial and final water storage are the same each year), the annual recharge was calculated as the excess of precipitation over actual evaportranspiration. Table 2.1 shows the calculated recharge for the Morton and the Thornthwaite-Mather methods. Only the Morton method produced results indicating that recharge would occur. Wallace suggested that of the models tested, the Morton model was preferred because its development and calibration included arid sites (although it was not calibrated specifically to the Hanford Site).

Wallace (1978) also computed recharge for two short-term data sets (19661970 and 1971-1975) using the Morton model. These time periods have average precipitation values of 14.1 and $17.1 \mathrm{~cm} / \mathrm{yr}$, respectively. The corresponding AET values were computed to be 3.0 and $0 \mathrm{~cm} / \mathrm{yr}$, respectively (Table 2.1). It is interesting to note that increasing the precipitation values increases the computed evapotranspiration, since the higher average rainfall years produce higher AET values. The calculated recharge was therefore less in the wetter years. This result is opposite that normally expected, and suggests that changes in climate that cause changes in precipitation are sufficiently complex that estimating recharge as some fraction of the annual precipitation is not appropriate. These calculations suggest that methods for estimating recharge from climate data alone can produce significantly different recharge results. Because site-specific recharge is known to be a function of more parameters than climate, and because relatively small changes in climate parameters can have a substantial influence on predicted evapotranspiration and subsequently 
TABLE 2.1. Recharge Estimates at the Hanford Site Using Climate Models(a)

\begin{tabular}{|c|c|c|c|c|c|c|}
\hline \multirow[b]{2}{*}{ Time Period } & \multirow{2}{*}{$\begin{array}{l}\text { Precipi- } \\
\text { tation } \\
\text { (cm/yr) }\end{array}$} & \multirow{2}{*}{$\begin{array}{c}\text { PET } \\
(\mathrm{cm} / \mathrm{yr}) \\
\end{array}$} & \multicolumn{2}{|c|}{ AET $(\mathrm{cm} / \mathrm{yr})$} & \multicolumn{2}{|c|}{ Recharge $(\mathrm{cm} / \mathrm{yr})$} \\
\hline & & & Morton & Thornthwaite & Morton & Thornthwaite \\
\hline $1966-1970$ & 14.1 & 141.6 & 11.1 & n.d. & 3.0 & n.d. (b) \\
\hline $1971-1975$ & 17.1 & 142.4 & 17.3 & n.d. & 0.0 & n.d. \\
\hline $\begin{array}{r}\text { Long-term } \\
\text { averages }\end{array}$ & 15.9 & 139.2 & 14.7 & 15.9 & 1.2 & 0 \\
\hline
\end{tabular}

(a) After Wallace (1978).

(b) n.d. = not determined.

on recharge estimates, methods that rely on climate alone should not be used for predictions of recharge at Hanford. For this reason, the Morton method is not recommended.

\subsubsection{Thornthwaite-Mather Model}

In addition to Wallace $(1978$,$) Gutknecht et al. (1980) and Whelan et al.$ 1987) used the Thornthwaite-Mather (T-M) model, or modifications of it, to assess recharge at Hanford. The T-M model was developed to calculate average potential evapotranspiration from mean monthly temperature data. The basic formula requires only temperature input and is an empirical index of evaporation from well-watered surfaces. It is based largely on evaporation and plant water-use data from central and eastern United States. In addition to temperature, estimates of rooting depth and soil water storage are required. In the T-M formulation, no consideration is given for temporal changes in vegetation type (such as might be created by fires or other disturbances), so this limitation must be accounted for empirically by altering the rooting depth or water storage factors. The plant rooting depths themselves are empirically derived parameters and have little to do with measured rooting depths, particularly for desert plants. Soil moisture retention tables based on soil texture properties are used to obtain the amount of water stored in the "root zone." From a knowledge of the root zone water capacity, the amount of soil moisture retained in the soil can be calculated and related to a given amount of evapotranspiration. 
In the T-M model the actual evapotranspiration (AET) is computed as a linear function of PET and the soil water status (SWS) such that AET = (SWS/AW) (PET), where SWS is the actual soil water status (i.e., the actual water stored expressed in inches or centimeters) in the root zone and AW is the total available water capacity (determined from a textural estimate of the difference between the "field capacity" and the "wilting-point" water content). A detailed discussion of this methodology is provided by Gutknecht et al. (1980; see their Appendix B) and Whelan et al. (1987). The model treats the soil as a box or storage bin of finite capacity. When the soil water is depleted (i.e., the soil water is at the wilting point), the bin is empty and AET is zero. The analysis is typically done on a monthly basis, and tabular data are provided for all the water balance components (e.g., precipitation, runoff, moisture storage, and drainage). Gutknecht et al. (1980) estimated both PET and AET for the Pasco Basin (which includes Hanford) using Hanford Meteorological Station data and data from 39 other weather stations. Soils data used included Soil Conservation Service county maps, a Hanford Site soil survey (Hajek 1966), and Columbia Basin irrigation guidelines (USDA 1973). They estimated that the effective root zones for sagebrush and cheatgrass were 1.3 and $0.5 \mathrm{~m}$, respectively. The computed AET was nearly equal to the precipitation for almost all of the Hanford Site. Although not presented in their report, values of recharge at the Hanford Site computed from their analysis ranged from 0 to about $0.25 \mathrm{~cm} / \mathrm{yr}$ for the waste site locations on the 200 Area plateau (Dove et al. 1982; Wukelic et al. 1981; Foote et al.1980).

A water balance model that uses a modified version of the T-M approach has recently been proposed by Whelan et al. (1987) as part of a Remedial Action Priority System (RAPS). The major difference between the whelan (RAPS) model and that used by Gutknecht et al. (1980) is that it accounts for variations in plant cover directly by partitioning the AET according to the percent cover and accounts for water storage as snow in the winter. The RAPS methodology is used primarily in comparing and ranking hazardous waste sites and would not be used directly in assessing recharge at Hanford. It has the capability of being calibrated to specific site conditions and providing initial estimates of the consequence of specific site management practices (i.e., placement of covers over a waste site compared to no cover placement). However, it relies on the $T-M$ assumptions of monthly climate averages, and therefore it does not account 
for daily variations (i.e., snowmelt events, thunderstorms, etc.) that may be important at Hanford. The use of RAPS methodology for estimating site-specific recharge at Hanford is not recommended.

\subsubsection{USGS Mode1}

The U.S. Geological Survey (USGS) has recently developed a regional groundwater model for the Columbia Plateau regional aquifer system. A component of this model was used to estimate recharge for the Hanford Site (Bauer and Vacarro 1986). Documentation of the deep drainage (recharge) model developed by the USGS is provided by Bauer and Vaccaro (1987). The recharge component of this model is similar to the T-M model but is more detailed in its accounting for daily fluctuations of weather and in its handling of topographic features and other key factors influencing recharge. As in the modeling effort of Gutknecht et al. (1980), the test area is divided into a grid network and water balance parameters are subsequently calculated for each grid element. The USGS used grid spacings that varied from 0.25 to 1.0 square miles. The following physical processes were simulated at each grid element: 1) snow accumulation and snowmelt; 2) interception of precipitation; 3 ) surface runoff; 4) evaporation from foliar cover; 5) evaporation from unshaded bare soil; and 6) plant transpiration. The model accounts for soil type, land use, plant growth, altitude, slope, and aspect, and each grid element is assigned individual values for each process. The model accounts for runoff using methods developed by the Agricultural Research Service (Wight and Neff 1983) and for surface evaporation using methods developed by Saxton, Johnson and Shaw (1974). Soils data were obtained from interpretations of soil survey maps, and plant cover data were obtained from aerial photography and Hanford Site reports.

The USGS model computes water balance on a daily basis. Simulations were made by Bauer and Vaccaro (1986) using historical climate data from the Hanford Site for a test period of 21 years $(1957-1977)$. The model was run in two ways. First, the actual daily climate values were used to predict annual recharge, and the average recharge value for the 21-year period was computed for each grid element and for the entire site. Subsequently, the average daily values for the 21 years were used, and the model was run until the annual recharge obtained a constant value. Results tabulated from the first runs reflect the variable nature of the climate, with the recharge varying from near zero to 
as much as $5.8 \mathrm{~cm} / \mathrm{yr}$ during the 21-year test period with an average value of $1.2 \mathrm{~cm} / \mathrm{yr}$ for the entire site. In contrast, taking the 21-year averages for each day and computing a steady-state recharge produced an average recharge value of $0.2 \mathrm{~cm} / \mathrm{yr}$ for the entire site. The effect of averaging the data is clearly apparent. Table 2.2 shows the results for the two simulations. Bauer and Vacarro concluded that the variations in frequency and distribution of rainfall and other climate variables played such a major role in determining recharge that daily input, rather than monthly or yearly averages, would be required to accurately predict recharge for the Hanford Site.

Since the publication of the Bauer and Vacarro (1986) report, additional simulations run by the USGS have shown that the average recharge for the 21-year test period may be less than the 0.2 to $1.2 \mathrm{~cm} / \mathrm{yr}$ values by a factor of about $30 \%$ (personal communication, H. Bauer, USGS, Seattle, Washington, June 1987). Slight changes in the rooting-depth algorithm plus an accounting for wintertime evaporation (sublimation) increased the predictions of evaporation, thus lowering the annual recharge estimates.

\subsubsection{UNSAT-H Model}

Fayer, Gee and Jones (1986) have documented a computer code used to predict unsaturated-zone water flow at Hanford. Versions of this code have been used to simulate typical climate, soil, and plant conditions that might exist

TABLE 2.2. Simulations of Recharge at the Hanford Site(a)

\begin{tabular}{ll}
$\begin{array}{c}\text { Recharge Based on } \\
\text { Actual Daily Climate } \\
(\mathrm{cm} / \mathrm{br})\end{array}$ \\
\hline Maximum & \\
Minimum & 5.8 \\
Average & 0.05 \\
(n) & 1.2
\end{tabular}

(a) From Bauer and Vacarro (1986).

(b) 21-year record.

\begin{tabular}{ll}
$\begin{array}{c}\text { Recharge Based on } \\
\text { Average Daily Climate } \\
(\mathrm{cm} / \mathrm{yr})\end{array}$ \\
\hline Maximum & 3.1 \\
Minimum & 0 \\
Average & 0.2
\end{tabular}


if protective barriers were placed over selected waste sites at Hanford (Fayer et al. 1985; Fayer 1987). The model is deterministic in that it relies on specific climate, soil, and plant data as input and generates values for infiltration, evaporation, redistribution, and drainage from these input data. The UNSAT-H model is more fundamentally based than the T-M type models. Water retention characteristics of multiple soil horizons are incorporated directly into the model. Unlike any of the models previously described, UNSAT-H utilizes a water potential (head) formulation based on Richards' equation to calculate water flow (infiltration, redistribution, and drainage) in the soil and a vapor diffusion model to calculate the water vapor flow below the soil surface (Fayer, Gee and Jones 1986). Evapotranspiration is calculated utilizing site-specific plant and soil data (plant and soil hydrologic characteristics) as inputs. In its present form, this model can simulate transient (hourly or less) rainfall events that may influence recharge. It incorporates key features of the Hanford Site that are currently thought to affect recharge, including daily climate variations and site-specific plant and soil data. The UNSAT-H model has been validated using analytical solutions for infiltration (Fayer, Gee and Jones 1986), and is currently being calibrated to Hanford Site lysimeter data and tested against field data sets. Data from a suite of barrier tests that will be available during the next several years will provide a range of soil, plant, and $c$ limate conditions with which to test and validate the UNSAT-H model (Adams and Wing 1987). 


\subsection{LYSIMETER STUDIES}

Several lysimeter studies have been conducted at Hanford during the past 15 years. Reviews of past work with lysimeters for recharge and water balance measurements have been reported previously (Gee and Heller 1985; Gee and Jones 1985). Presented here is an update of the lysimeter measurements that have been obtained to estimate recharge at the Hanford Site.

\subsection{THE 200 AREA DEEP LYSIMETER}

Figure 3.1 diagrams the 18.5-m-deep closed-bottom lysimeter that is located about $2 \mathrm{~km}$ south of the 200-East Area at the Hanford Site [see Gee and Heller (1985) for a summary of the studies conducted at this lysimeter and a companion open-bottom lysimeter]. The measurements of water balance (water content and water storage changes) at this lysimeter have been used to support the argument that recharge is virtually zero for the Hanford Site. Last, Easley and Brown (1976) state that the soil moisture data collected using neutron probes at the lysimeter site during the water years 1974-1975 and 1975-1976 "confirm the ability of the semiarid Hanford environment to prevent percolation of meteoric water down to the water table on the 200 Area plateau."

The National Academy of Sciences (1978), relying largely on reports related to these two lysimeters, stated that additional testing for recharge by lysimetry and related techniques is justified "since it furthers the end of finally resolving a general question of radioactive waste management: is a thick unsaturated zone in a semi-arid environment or arid region, as at Hanford, a dependable barrier against, or an open route for disposal of radionuclides into the biosphere? Evidence thus far available favors the barrier concept..."

The opinion that recharge is very low because Hanford is an arid site seemed to be supported by early data from the moisture profiles at the 200East Area lysimeters. Jones (1978) was not as optimistic as other investigators that these lysimeters gave evidence of zero recharge. Rather than zero recharge, he reasoned that the observation of relatively uniform moisture profiles with depth indicated that there was a constant water potential 


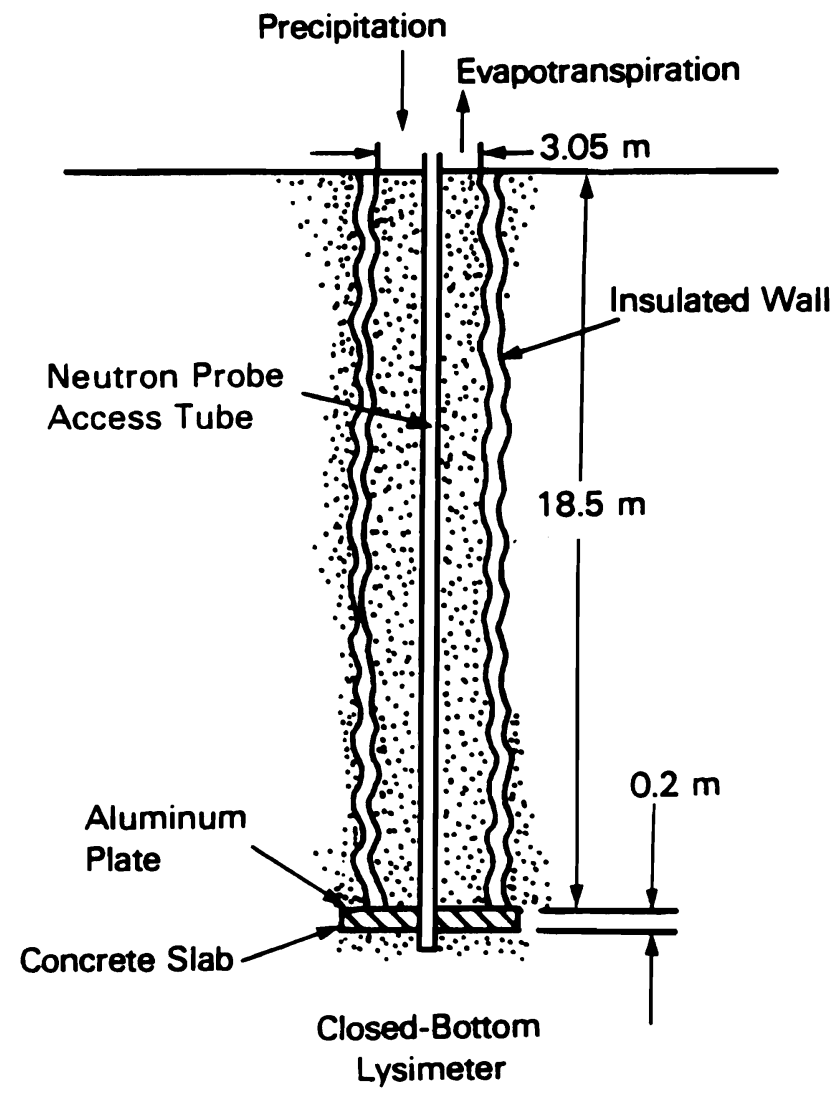

FIGURE 3.1. Schematic Diagram of the 200-East Area Closed-Bottom Lysimeter

and that, if this were the case, that water could be moving downward under a gravity gradient (i.e., the total head gradient was near unity). He concluded that one interpretation of the neutron probe data from the site was that a flux of at least $0.5 \mathrm{~cm} / \mathrm{yr}$ could be moving steadily downward in the lysimeters.

Conflicting interpretations suggested that additional measurements over time were needed to determine the rate at which water is moving. If recharge had been occurring at a constant rate in the lysimeter, there should be an increase of water content detectable as a change in water storage. If a measurable amount of water infiltrated below the root zone, it also would be expected that a wetting front would move down into the soil profile, eventually resulting in an accumulation of moisture at the bottom of the lysimeter. 
Neutron probe sampling during 1971 to 1978 gave indication of moisture accumulation in the lower depths of the closed-bottom lysimeter.

In early October 1985, the closed-bottom lysimeter was sampled for water content by coring the lysimeter. The data show that water contents at all depths had not changed by more than about $0.5 \mathrm{wt} \%$ during the 14-year period 1971 to 1985. In fact, there was an apparent loss of water storage during this time period. In Table 3.1, the measured water contents taken from a 10-cm borehole in 0ctober 1985 are compared directly with the moisture contents taken from the lysimeter when it was installed in 1971 (Hsieh, Brownell and Reisenauer 1973). The error in gravimetrically determined mass wetness (water content) is estimated to be less than $0.1 \mathrm{wt} \%$. By directly comparing (water content) values for these two time periods, the problems inherent with neutron probe readings described by Jones (1978) and Gee and Heller (1985)

TABLE 3.1. Water Content Data from the Closed-Bottom Lysimeter in the 200-East Area

Soil Depth

\begin{tabular}{r}
$(\mathrm{m})$ \\
\hline $0-1.5$ \\
$1.5-3.0$ \\
$3.0=4.6$ \\
$4.6-6.1$ \\
$6.1-7.6$ \\
$7.6-9.1$ \\
$9.1-10.7$ \\
$10.7-12.2$ \\
$12.2-13.7$ \\
$13.7-15.2$ \\
$15.2-16.8$ \\
$16.8-18.3$
\end{tabular}

Percent Dry Weight

\begin{tabular}{|c|c|c|}
\hline November 1971(a) & October $1985(\mathrm{~b})$ & Difference \\
\hline $\begin{array}{l}3.4 \\
3.5 \\
3.2 \\
3.3 \\
3.1 \\
2.8 \\
3.1 \\
2.8 \\
2.4 \\
2.4 \\
2.5 \\
2.6 \\
\end{array}$ & $\begin{array}{l}2.8 \\
2.6 \\
2.9 \\
2.9 \\
2.8 \\
2.8 \\
3.0 \\
2.9 \\
2.9 \\
2.8 \\
2.8 \\
2.8 \\
\end{array}$ & $\begin{array}{c}-0.6 \\
-0.9 \\
-0.3 \\
-0.4 \\
-0.3 \\
0 \\
-0.1 \\
+0.1 \\
+0.5 \\
+0.4 \\
+0.3 \\
+0.2\end{array}$ \\
\hline 2.9 & 2.8 & -0.1 \\
\hline
\end{tabular}

Mean Soil Suction

$(\mathrm{MPa})(\mathrm{c})$
Mean K( $(\theta)(\mathrm{cm} / \mathrm{yr})$

0.5

$2.0 \times 10^{-3}$
$-0.3$

$1.3 \times 10^{-3}$

(a) From Table 2 of Hsieh, Brownell and Reisenauer (1973).

(b) Appendix B of Fayer, Gee and Jones 1986, values represent the average of five $1-\mathrm{ft}$ measurements.

(c) Estimated from Figure 6 of Hsieh, Brownell and Reisenauer (1973).

(d) Estimated from Figure 7 of Hsieh, Brownell and Reisenauer (1973). 
are eliminated; the differences should reflect changes in moisture contents within the error of spatial sampling of a "homogeneous" soil column. The slight increase in water content with time in the lower profile suggests that there has been a redistribution of water (probably as a result of the downward pull of gravity). However, there has not been a significant accumulation of water and it appears that little, if any, surface water has infiltrated below the $4-m$ depth.

The observation that the total storage is less after almost 14 years indicates that some mechanism is responsible for preventing significant deep drainage in this lysimeter. The average initial soil suction (tension) (in November 1971) was $0.5 \mathrm{MPa}$, which apparently dried to $0.8 \mathrm{MPa}$ in October 1985. These values are associated with low water contents ( $3 \%$ wt\%) for this lysimeter soil. The calculated water flow for this soil ranges from $20 \mathrm{x}$ $10^{-4}$ to $0.7 \times 10^{-4} \mathrm{~cm} / \mathrm{yr}$, utilizing the calculated unsaturated hydraulic conductivity (Hsieh, Brownell and Reisenauer 1973) and assuming a unitgradient flow condition.

Gee and Heller (1985), Gee and Jones (1985), and Fayer, Gee and Jones (1986) speculated that plant water uptake was responsible for the lack of deep drainage in this lysimeter; plants were observed growing on the lysimeter. Fayer, Gee and Jones (1986; Appendix B) used computer models to simulate the water balance in this lysimeter. When no plants were included in the simulation, the water storage increased by about $17 \mathrm{~cm}$ during the 14year test period. When plant cover was simulated, the water storage cycled during the test period and showed an apparent decrease in storage similar to the measured value.

These simulations do not prove that plant cover was entirely responsible for the lack of "drainage" at this lysimeter, but the results do support the argument that plant cover can greatly alter the water balance under these desert (arid) climate conditions. Because the lysimeter is not a drainagetype lysimeter, estimates of drainage from this lysimeter must be made indirectly from changes in water content of the sampled soil profile. Considering the information in Table 3.1, we can speculate that the soil in this lysimeter would have to become wetter throughout the profile before drainage would be expected. Based on the calculated hydraulic conductivity and water 
retention characteristics (Hsieh, Brownell and Reisenauer 1973), no drainage would be estimated to occur until the water contents in the lower few meters of the lysimeter increased to more than 6 or $7 \mathrm{wt} \%$ (10 or $11 \mathrm{vol \%}$ ) and the soil at the bottom of the lysimeter saturated. This observation suggests that an increase of storage in excess of $16 \mathrm{~cm}$ would be required before drainage would occur (i.e., standing water collected in the bottom of the lysimeter). If plants were removed from this lysimeter and the lysimeter were maintained without vegetation for several years, it would be possible to confirm the hypothesis that evapotranspiration has been responsible for the lack of drainage or recharge at this lysimeter and provide additional data that would be useful in calibrating models for recharge predictions.

\subsection{LYSIMETERS AT THE BWTF}

Three lysimeters located at the Buried Waste Test Facility (BWTF), about $6 \mathrm{~km}$ northwest of the 300 Area and adjacent to the 300-N Burial Ground (Figure 3.1), have been monitored for drainage during the past several years. The data collected from these lysimeters are in sharp contrast to the data obtained from the 200 Area closed-bottom lysimeter. The results from the BWTF lysimeter tests have shown that significant quantities of water drain from both bare soil surfaces and from surfaces that have been vegetated with shallow-rooted grasses. The differences between 200 Area and 300 Area data will be discussed in the following sections.

Figure 3.2 shows a schematic cross-section of the lysimeter arrangement at the BWTF. This facility was installed during a period of 9 months (May 1978 through February 1979). Details of the construction are provided by Phillips et al. (1979).

Drainage data from the South Caisson (SC), an 8.2-m-deep drainage lysimeter at the BWTF, have been collected since early 1981. Data collected through 1982 from this lysimeter have been reported previously (Jones, Gee and Campbel1 1984; Gee and Jones 1985). From early March of 1983 through February of 1984, the South Caisson was not monitored for drainage, because of lack of funding. The data collection resumed in late February of 1984 and has continued without interruption since that time. 


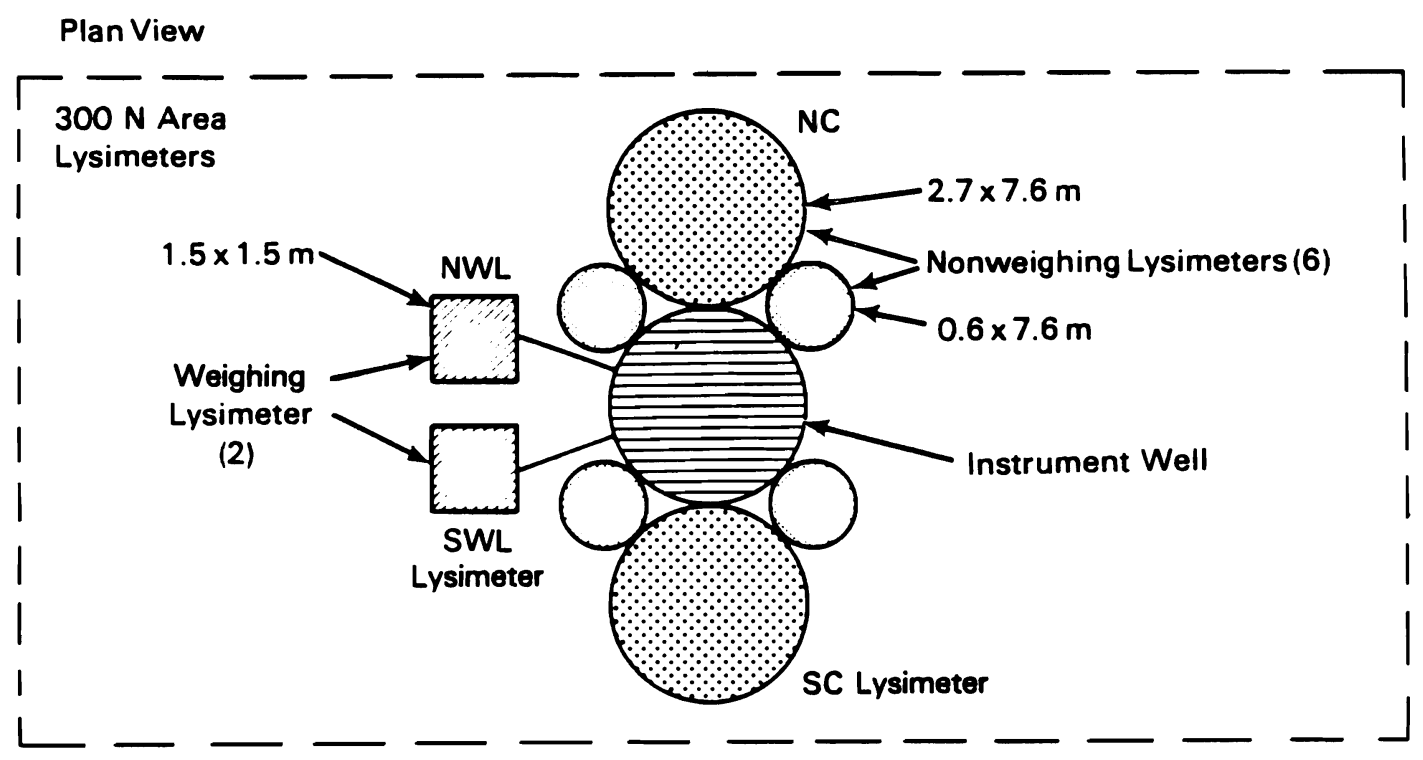

\section{Cross Section}

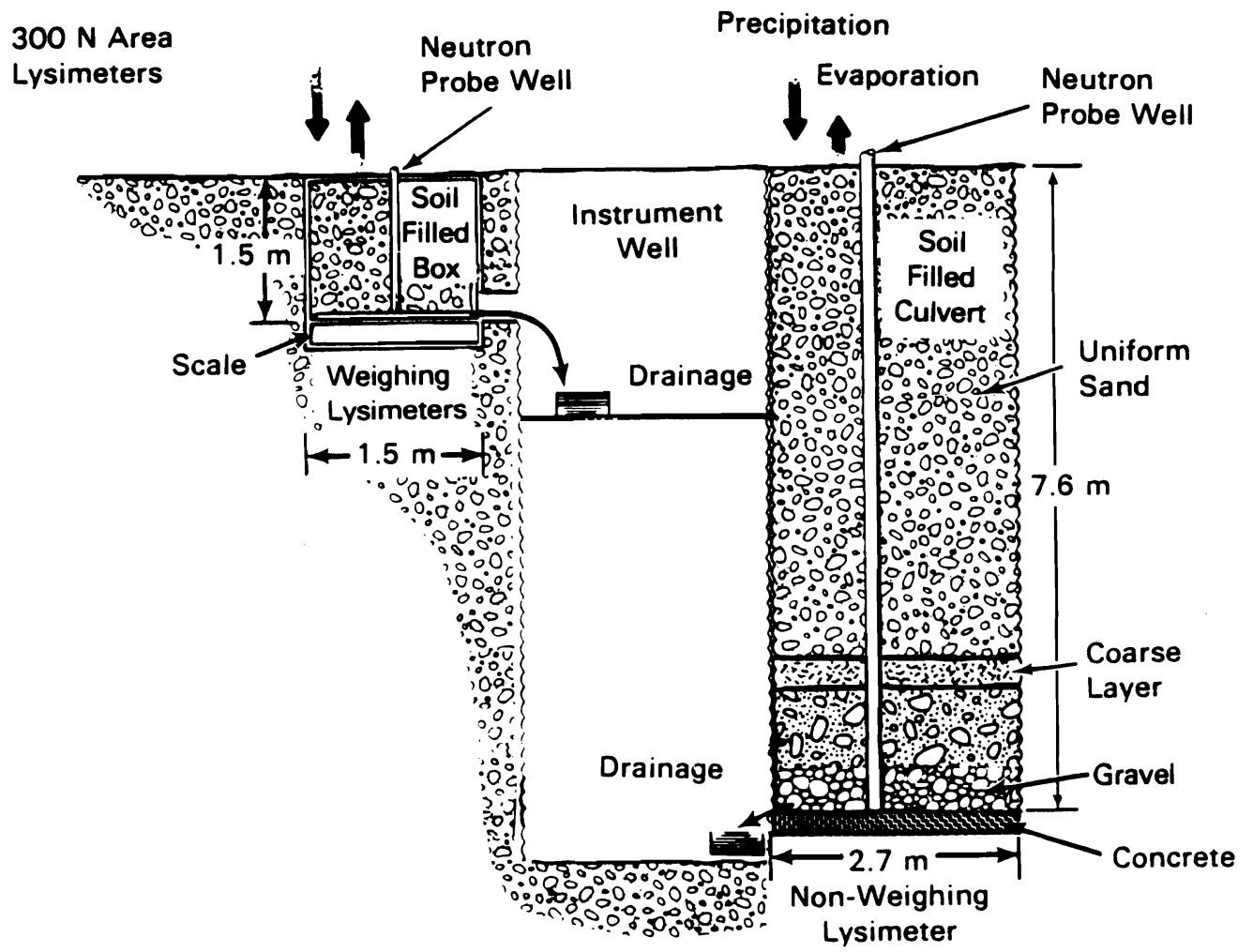

FIGURE 3.2. Schematic Diagram of the Lysimeters at the Buried Waste Test Facility Site (BWTF) in the 300 Area 
Drainage values from the SC lysimeter for January 1984 through June 1987 are presented in Figure 3.3. The drainage was measured by collecting water from the bottom of the lysimeter (as shown in Figure 3.2) using 40 liter plastic carboys, which were brought back to the laboratory and weighed on a precision balance to $\pm 10 \mathrm{~g}$. Based on an average of 26 (i.e., biweekly) weighings throughout the year, the resolution in annual drainage is \pm 0.004 $\mathrm{Cm} \mathrm{H}_{2} \mathrm{O}$ for the SC lysimeter. (Similar resolution was obtained in measuring drainage for the other lysimeters for which data are reported in this document.) The reported drainage numbers represent minimum drainage because leakage may have o ccurred from the lysimeters or water may have evaporated from the carboys. Drainage rates for the SC lysimeter have remained relatively constant for the past 3.5 years and have averaged about $10 \mathrm{~cm} / \mathrm{yr}$.

These data indicate that the recharge rate for bare, coarse-textured soils at the BWTF has been more than half of the annual precipitation during the past 3.5 years. Average precipitation at the BWTF for this period of time was $16.7 \mathrm{~cm}$. This value is very close to the long-term (1912-1980) precipitation average of $16.0 \mathrm{~cm} / \mathrm{yr}$ recorded for the Hanford Site (Stone et al. 1983). The precipitation at the BWTF site since 1979 has been comparable to the precipitation measured at the Hanford Meteorological Station for all but 2 years, 1982 and 1984. The 8.5-year (January 1979 to June 1987) average precipitation for the BWTF and the Hanford Meteorological Station is 19.7 and $18.9 \mathrm{~cm} / \mathrm{yr}$, respectively, or a difference of 1ess than $5 \%$. These data suggest that annual precipitation at the BWTF is similar to the precipitation on the 200 Area plateau (as measured at the Hanford Meteorological Station).

Water storage, measured using down-well neutron probes, has been determined during the past 9 years at the SC lysimeter (Figure 3.2) in the 300 Area. Figure 3.5 shows that water storage changes have been significant over the life of the lysimeter. The large increase in storage during 1983 is associated with drainage water accumulating in the bottom of the lysimeter during the period of time that the drainage was not monitored. After 1983, annual water storage changes have ranged from 6 to $10 \mathrm{~cm} / \mathrm{yr}$ as a result of wintertime accumulation followed by surface evaporation and relatively constant drainage. 


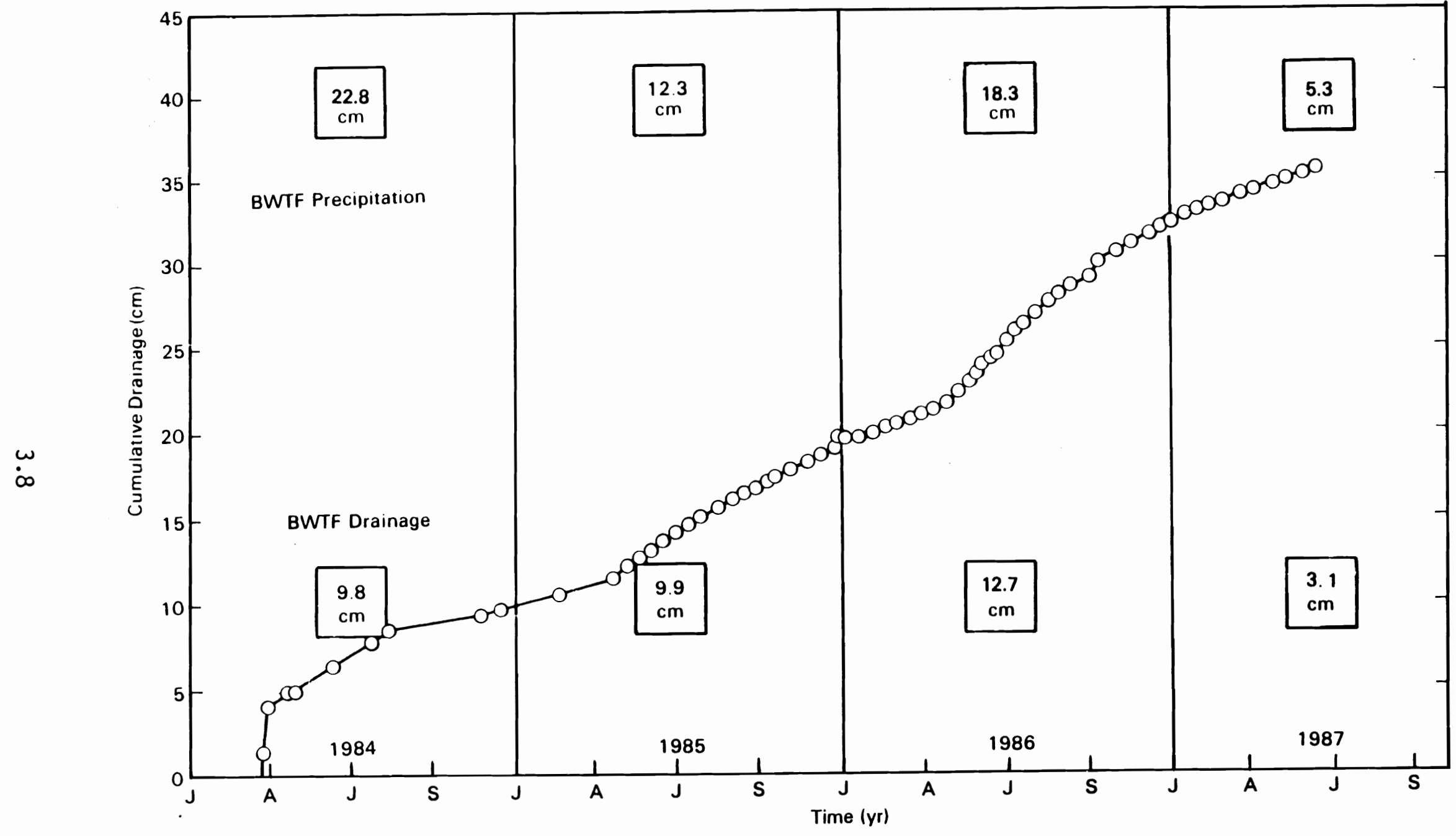

FIGURE 3.3. Drainage from the South Caisson (SC) Lysimeter at the Buried Waste Test Facility Site (BWTF) Near the 300 Area, January 1984 through June 1987 


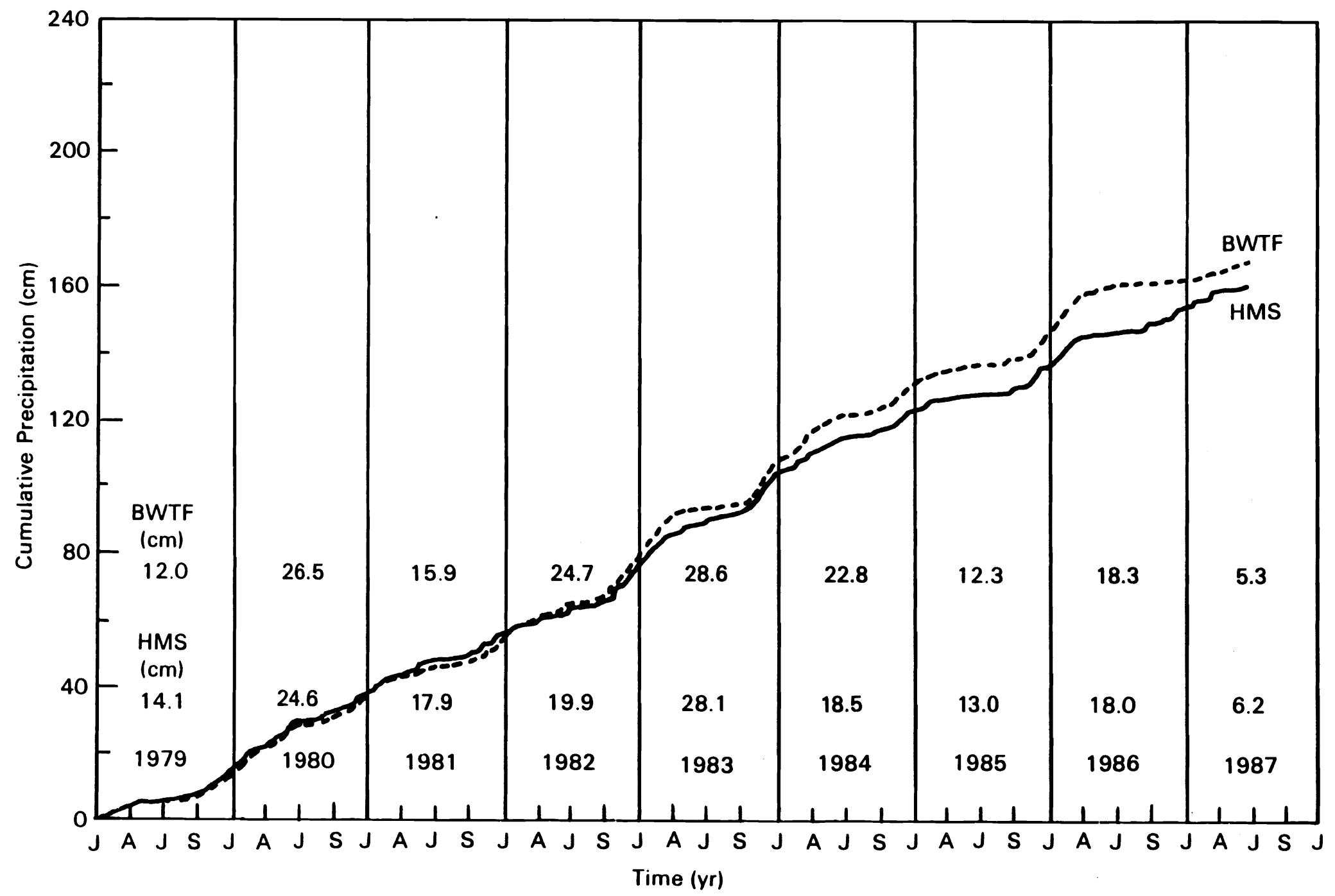

FIGURE 3.4. Comparison of the Buried Waste Test Facility Site (BWTF) and the Hanford Meteorological Station (HMS) Precipitation, January 1979 Through June 1987 


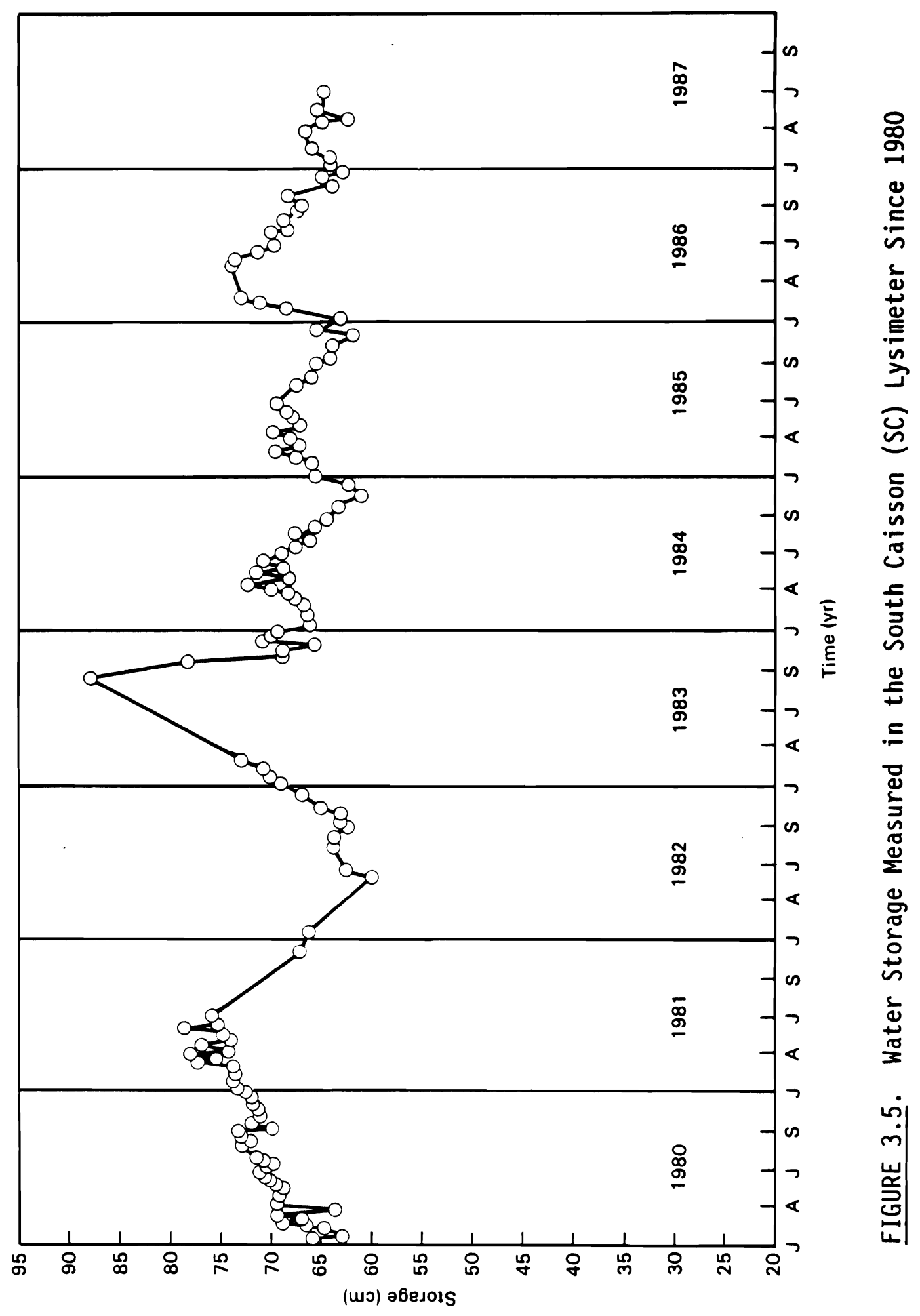


In May of 1987, tensiometers were installed in side-access holes of the SC lysimeter. Figure 3.6 shows the computed total head (suction plus gravity) from the tensiometer and gravity data. The data confirm that unitgradient conditions prevail in this lysimeter. During installation of the tensiometers, the soil was sampled gravimetrically. The gravimetric water contents for the entire profile averaged about $7 \mathrm{wt} \%$, which was about twice that found in the 200 Area closed-bottom lysimeter.

The north (NWL) and south (SWL) weighing lysimeters (Figure 3.2) have somewhat different histories than the SC drainage lysimeter. The NWL was irrigated periodically from June 1979 through January 1981 with $85 \mathrm{~cm}$ of irrigation water. After January 1981, irrigation was discontinued on the NWL; the SWL and the SC lysimeter were not irrigated. During 1982 the NWL, SWL, and the SC lysimeter had measured drainage values of 5.3, 3.2, and $5.6 \mathrm{~cm}$, respectively (Gee and Heller 1985). In March 1983, the SWL was revamped to evaluate the effects of vegetation on drainage. Soil was removed, the suction-candle drainage system was replaced, and the soil was repacked in the lysimeter. The surface of the SWL was then sodded with shallow-rooted cheatgrass (Bromus tectorum L.) and Sandberg's bluegrass (Poa secunda) taken from an adjacent area. Since that time, the surface of the SWL has remained vegetated. The NWL was excavated in August 1986, and new suction candles were installed. The soil in the NWL was replaced in January 1987, and monitoring of this lysimeter was resumed at that time.

Drainage values from the NWL and the SWL lysimeters are shown in Figure 3.7 and are tabulated in the Appendix. Water storage in the top $1.2 \mathrm{~m}$ of the NWL, SWL, and SC lysimeters is shown in Figure 3.8. Drainage was less in the SWL than in the NWL, and averaged about $6 \mathrm{~cm} / \mathrm{yr}$ in the SWL for the past 3 years (1984-1986) compared to $10 \mathrm{~cm} / \mathrm{yr}$ for the SC lysimeter. The lower drainage from the SWL is attributed to evapotranspiration (i.e., water loss from the vegetated surface).

The variable drainage rate of the SWL has resulted from a combination of precipitation variations and changes in plant cover. Table 3.2 lists the surface condition of the SWL since 1979. The large drainage observed at the SWL resulted from precipitation that infiltrated the soil during the winters of 1983-1984 and 1985-1986 and moved below the shallow root zone of the 


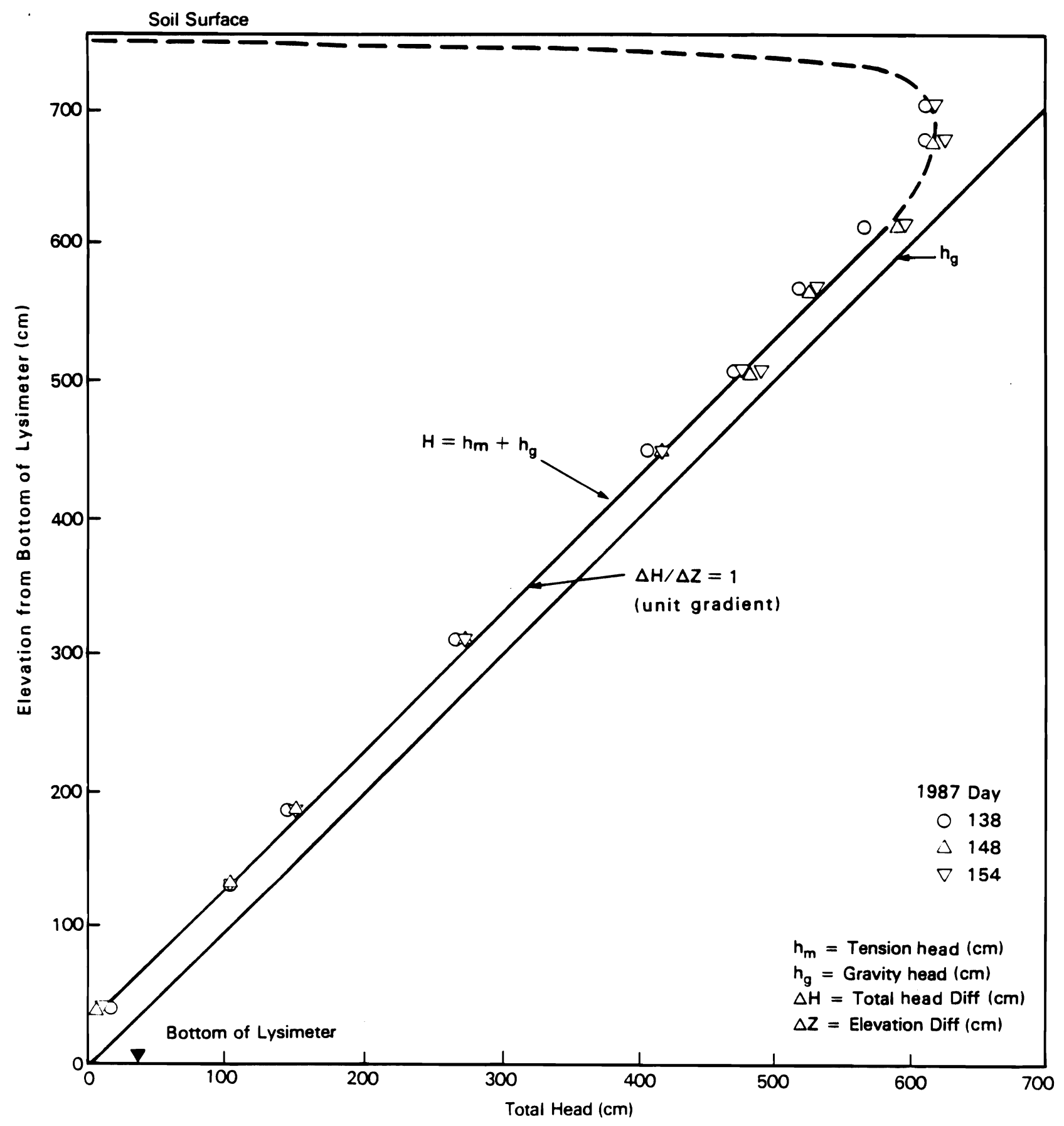

FIGURE 3.6. Total Head Values for the South Caisson (SC) Lysimeter at the Buried Waste Test Facility Site (BWTF) Near the 300 Area. 


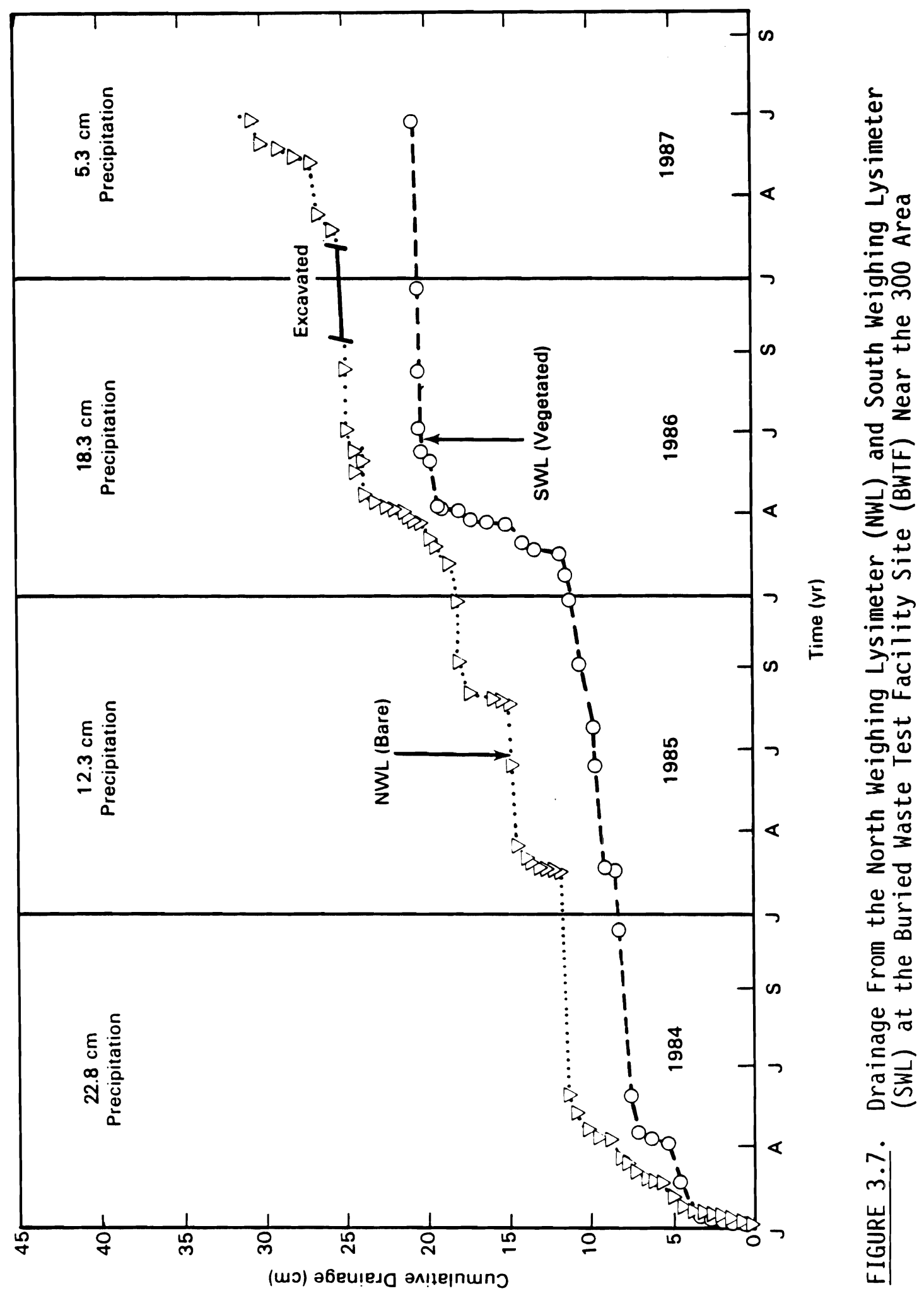




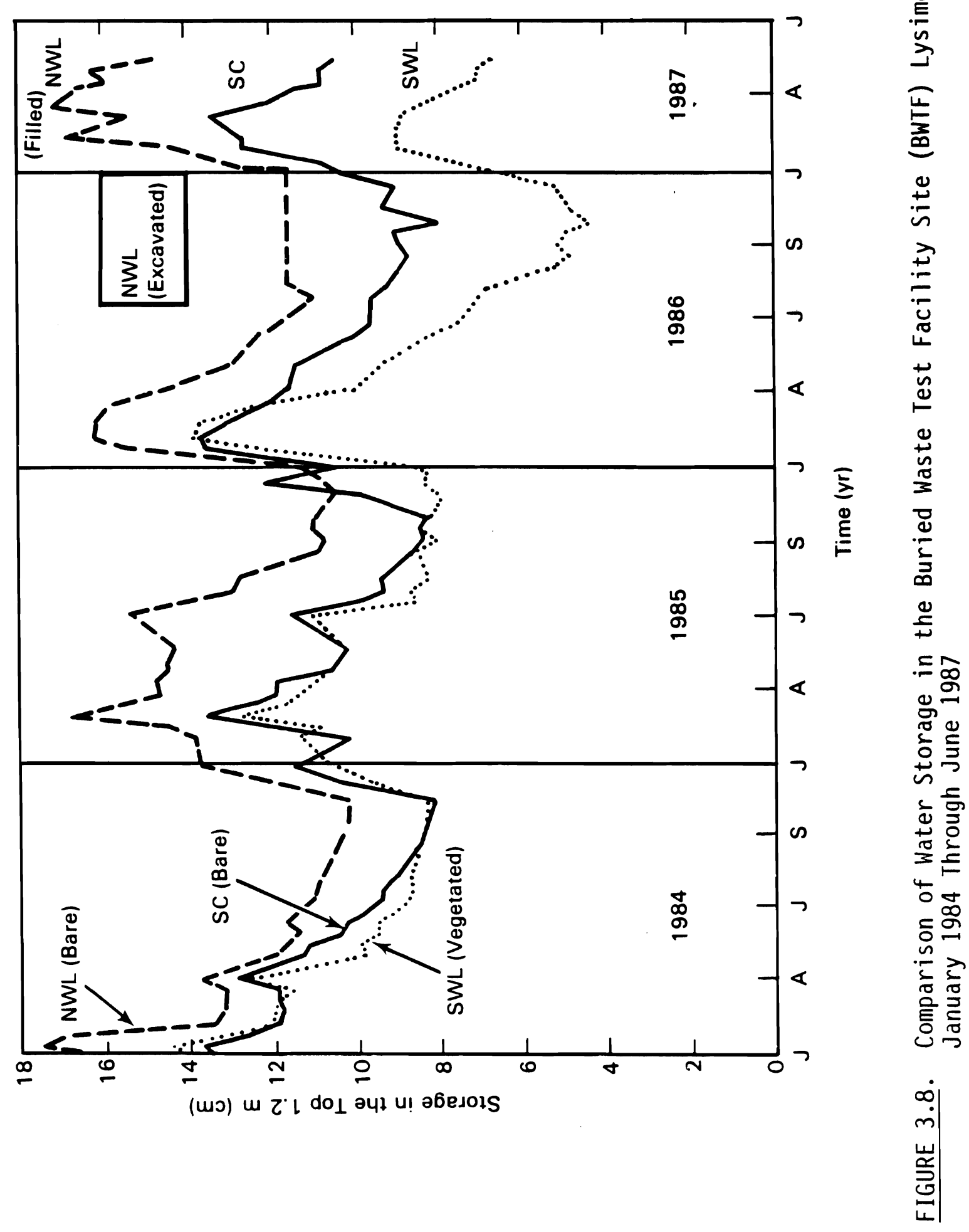


TABLE 3.2. Surface Cover of South Weighing Lysimeter (SWL) at the Buried Waste Test Facility Site (BWTF)

\begin{tabular}{ll}
$\frac{\text { Year }}{1979}$ & Surface Condition \\
\cline { 2 - 2 } 1980 & Bare \\
1981 & Bare \\
1982 & Bare \\
1983 & Transplanted to cheatgrass and Poa $(\sim 40 \%)$ cover $(a)$ \\
1984 & Cheatgrass, Poa ( $50 \%$ cover) \\
1985 & Cheatgrass, Poa (50\% cover) \\
1986 & Cheatgrass, Poa, Russian thistle (60\% cover) \\
1987 & Cheatgrass, Poa, mustard (75\% cover)
\end{tabular}

(a) Plant cover on SWL:

\begin{tabular}{|c|c|}
\hline Name & Common Name \\
\hline$\frac{\text { Bromus }}{\text { Poa tectorum }}$ L. & $\begin{array}{l}\text { Cheatgrass } \\
\text { Sandberg's bluegrass } \\
\text { Russian thistle (tumbleweed) } \\
\text { Jim Hill mustard (tumble mustard) }\end{array}$ \\
\hline
\end{tabular}

grasses growing on the lysimeter. A single tumbleweed (Salsola kali L.) was allowed to grow on the lysimeter during the summer of 1986. Since that time there has been no measurable drainage from the SWL, and the water storage in this lysimeter has decreased significantly (Figure 3.8 ). The large change in water storage for the SWL during 1986 can be attributed to early spring drainage followed by a significant amount of water $(>4 \mathrm{~cm})$ extracted from the soil by transpiration from the tumbleweed during the summer months. Phenology (i.e., growth patterns of emergence, leaf elongation, seed production, senescence, etc.) of plant cover is important in determining water loss by desert plants. While the tumbleweed was actively growing and transpiring, the cheatgrass and bluegrass were dead and contributed little, if anything, to soil water removal. The model simulation described earlier, using UNSAT-H for the 200 Area closed-bottom lysimeter (Fayer, Gee and Jones 1986), demonstrates water storage effects similar to those observed in the SWL.

That there has been no further drainage from the SWL in 1987 is attributed to the lack of sufficient winter precipitation to wet the soil above 
the "field capacity" (i.e., the soil did not wet sufficiently to be drained by the $100-\mathrm{cm}$ vacuum control imposed on the suction candles at the bottom of the lysimeter). The low water storage and an increased amount of vegetation cover (cheatgrass, bluegrass, and tumbleweed) during early 1987 (Table 3.2) were apparently sufficient to prevent water from percolating below the root zone. The increased grass cover is attributed to an unusually wet March (2.7 cm of precipitation, which was $267 \%$ of normal). The increased plant growth resulted in greater water loss by evapotranspiration, thus cycling water from the spring and summer rains back to the atmosphere rather than storing it in the soil.

These data illustrate the complex interactions between vegetation, soil, and climate that in combination may influence drainage rates at Hanford. The SWL data indicate that recharge can occur under conditions where shallowrooted plants (grasses) dominate the cover of a coarse-textured soil. The data also demonstrate that recharge can be reduced when deep-rooted plants (tumbleweeds) are present. The data further illustrate the interactions between precipitation, plant growth, and evapotranspiration. Predicting when recharge will occur given these surface and soil conditions requires a detailed knowledge of plant response to soil and climate variables that is often lacking. A limited amount of information about water use by plant communities typical of the Hanford site is available (Cline, Ursek, and Rickard 1977). However, information about plant response (phenology, rooting depths, etc.) to Hanford Site climate conditions (e.g., precipitation, temperature, net radiation, etc.) is not yet sufficiently detailed to provide accurate predictions of seasonal or annual evapotranspiration (ET). Further information about plant phenology, soil hydraulic properties, and climate variations are needed to predict the magnitude of drainage, particularly when shallowrooted plants are present.

Continued monitoring of the SWL (grass-covered) lysimeter is recommended. Weight changes, neutron probe water storage measurements, and detailed observations of the plant cover on the SWL during the next several years will help properly account for the ET component in the water balance. Comparison of lysimeter data from this site will provide estimates of surface water losses that occur with and without plants, and thus provide estimates 
of both evaporation and transpiration for model calibration tests for UNSAT-H or other arid-site water balance codes.

\subsection{OTHER 300 AREA LYSIMETERS}

During the past 3 years, two additional lysimeter installations located adjacent to the BWTF have become operational and have provided data that are pertinent to the evaluation of recharge at the Hanford Site: the Commercial Waste Test Facility (CWTF) and the Grout Waste Test Facility (GWTF) (Gee and Jones 1985). Both these facilities contain drainage-type lysimeters that have no vegetation growing on the surfaces. The CWTF has 10 operational lysimeters, and the GWTF has 2 presently in use. Significant drainage or water storage increases have been observed in all 12 lysimeters.

Jones and Skaggs (1987) reported that during a 1-year test period (September 1985-August 1986) the 10 bare-surface lysimeters at the CWTF averaged $12.3( \pm 1.2) \mathrm{cm} / \mathrm{yr}$ drainage. This is slightly more than the drainage obtained from the SC lysimeter at the BWTF during the same time period (Figure 3.3).

Unusual climatic events can have a significant impact on Hanford Site recharge. Observations on 3 of the 10 CWTF lysimeters indicated that snowmelt in March 1985 caused water from adjacent soil surfaces that were slightly elevated (about $1 \%$ slope) above the lysimeters to form a pond on the surface, infiltrate, and drain in a few days. The quantity of drainage was in excess of the annual precipitation. This observation illustrates the effects of rapid snowmelt and local topography in producing rapid drainage in Hanford soils. Waste site areas that have topographic relief such that runon is possible may experience elevated recharge if soils are coarse textured and bare.

The Grout Waste Test Facility adjacent to the BWTF has two gravelcovered lysimeters, that are 8.0-m deep, on which no plants are growing. In this respect, their surfaces are analogous to the surfaces that exist at the Tank Farm sites located in the 200 Areas. Neutron probe monitoring of these lysimeters for water storage indicated that they have accumulated between $65 \%$ and $85 \%$ of the precipitation that has occurred at the site since they were installed. The soils that were placed in these lysimeters were 
relatively dry, and they are just now beginning to drain. Drainage data and other information (water chemistry) from these lysimeters will be available from the Grout program during the next several years.

The drainage and water storage data from the CWTF and GWTF confirm that water infiltration into bare soils at the Hanford Site can be significant. With gravel surfaces tending to retard evaporation, much of the annual precipitation may infiltrate and eventually drain from the vadose zone into the ground water. Run-on in localized areas can cause drainage (recharge) that exceeds the annual precipitation. These observations provide insight into needs for good management of surfaces at waste burial sites at Hanford. Graveled and/or bare surfaces should be eliminated if reduction in onsite recharge is desired. 


\subsection{FIELD SITE DATA}

\subsection{AREA GRASS SITE}

This site is located about $5 \mathrm{~km}$ northwest of the 300 Area and about $2 \mathrm{~km}$ southeast of the BWTF (Figure 1.1). This area has burned at least twice in the past 10 years, most recently in August 1984. The site is covered with cheatgrass and Sandberg's bluegrass; the deep-rooted sagebrush and rabbitbrush were burned off before 1983. Water content and water storage at this site have been monitored since January 1983. Water storage data through June 1984 from this site analyzed by Gee and Kirkham (1984), suggested that drainage was occurring below the root zone at this site. The unsaturated conductivity was previously measured at one location on the 300 Area Grass Site using an instantaneous profile method (Gee and Kirkham 1984). In addition, the water balance of this site was modeled using the water flow code, UNSAT1D (Gee and Kirkham 1984). The simulation results utilizing the measured unsaturated conductivity data indicate that 3 to $5 \mathrm{~cm} / \mathrm{yr}$ could drain below the root zone at this site, depending on the climate and soil variations used in the model.

Figure 4.1 shows water storage data for the Grass Site since 1983, which indicate that storage changes have occurred below the $1-\mathrm{m}$ depth every year. These storage changes suggest that water is moving below the root zone. While direct measurement of the amount of drainage by neutron probes is not possible, storage changes below the root zone do provide qualitative evidence that recharge is occurring. The largest changes occurred in 1983, which was the wettest winter of the test period. Storage changes have persisted every year; however, they are smaller than the maximum change in 1983 which was about $8 \mathrm{~cm}$ (Figure 4.1).

A drainage study was initiated in 1987 to further evaluate the hydraulic properties of the soil at the Grass Site. This study required installation of deep tensiometers (deeper than $1 \mathrm{~m}$ ) and provided a nearly direct measure of the unsaturated conductivity by monitoring drainage using the combination of neutron probe and tensiometers. A report detailing the drainage measurements and the unsaturated hydraulic conductivity data obtained from these 


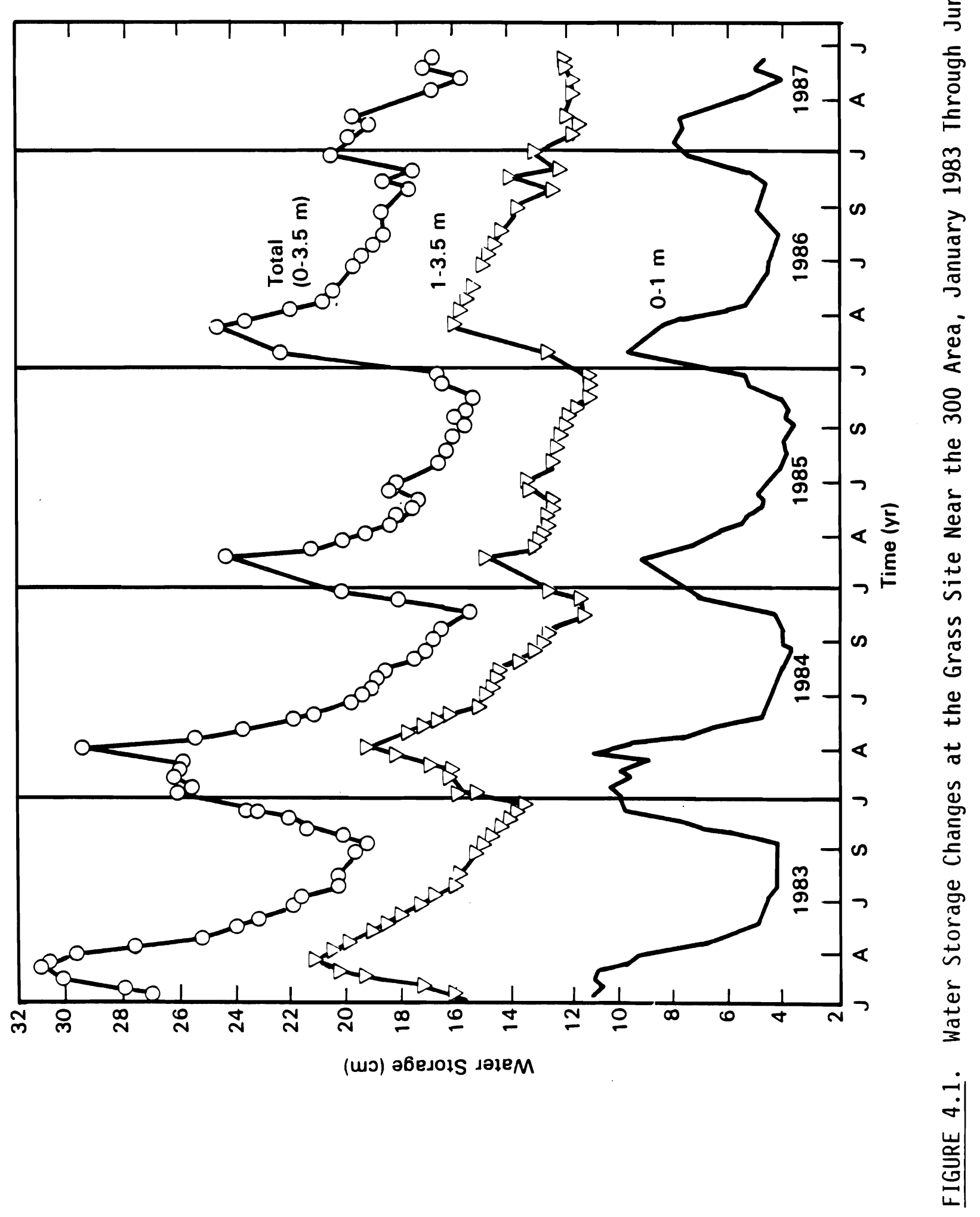


drainage measurements has been prepared and is to be published as part of the Comprehensive Data Base Task during the coming year. The results from the drainage tests suggest that water flow rates as great as 4 to $8 \mathrm{~cm} / \mathrm{yr}$ could be occurring at this site.

Work planned at this site includes monitoring the water storage changes, evaluating the phenology of the plant community, and quantifying the variations in hydraulic conductivity that occur in the soil profile of the site. In addition, a small drainage lysimeter installed at this site could evaluate the drainage rates occurring in coarse soils covered with only shallow-rooted grasses. The amount of drainage occurring can be confirmed by using tensiometers, monitoring the head gradients below the root zone, and estimating the hydraulic conductivity from instantaneous profile data. Tensiometers should be installed at selected depths below the root zone (e.g., 1-2 m). Such instrumentation would provide information about the direction as well as the magnitude of the water flow below the root zone.

Data collected at this site suggest that drainage is occurring, but that the exact amount has not been quantified. Drainage appears to be variable, ranging from 4 to as much as $8 \mathrm{~cm} / \mathrm{yr}$. Further quantification of plant characteristics and variations in hydraulic properties is needed to define the drainage rate of the coarse-textured soil at this site. Installation of a drainage lysimeter at this site would allow quantification of the drainage rate.

\subsection{MCGEE RANCH SITE}

The McGee Ranch site is located just across Highway 240 from the Yakima Barricade west of the 200 Areas (Figure 1.1). The soils in this area have been classified as Esquatzel and Warden silt loams (Hajek 1966). A recent testing of the soil depths at the site indicated that the fine-grained soils range in depth from 3 to $10 \mathrm{~m}$ (Last et al. 1987). This site has been selected as the area from which fine-grained soil will be taken to be used as part of the Hanford Site Protective Barriers. A preliminary study of soil characteristics suitable for use as a barrier material revealed that the soils here have suitable water-holding characteristics, and are present in sufficient quantity to supply most, if not all, the material needed for 
protective barriers at Hanford. Water storage and plant characteristics data from this site are being monitored to provide data critical to assessment of the adequacy of protective barriers.

Water content and water potential profiles were taken during the summer of 1986. Data from selected sites are shown in Tables 4.1 and 4.2. These data indicate that water contents and water potentials at the test plots are very low, suggesting that little if any water is draining from the root zone. Additional data from boreholes taken at this and other locations at the McGee Ranch, where deep-rooted plants (e.g., sagebrush, hopsage, etc.) are growing, indicate that the water potentials are so low in these soils that rates of flow are likely less than $0.1 \mathrm{~cm} / \mathrm{yr}$. This value is based on calculated hydraulic conductivity values for soil material of this type (Simmons and Gee 1981).

Actual measurements of water flow rates in these fine soils for dry conditions have not yet been obtained. However, measurements of drainage have

TABLE 4.1. Water Potential Data for McGee Ranch Site, July 1986

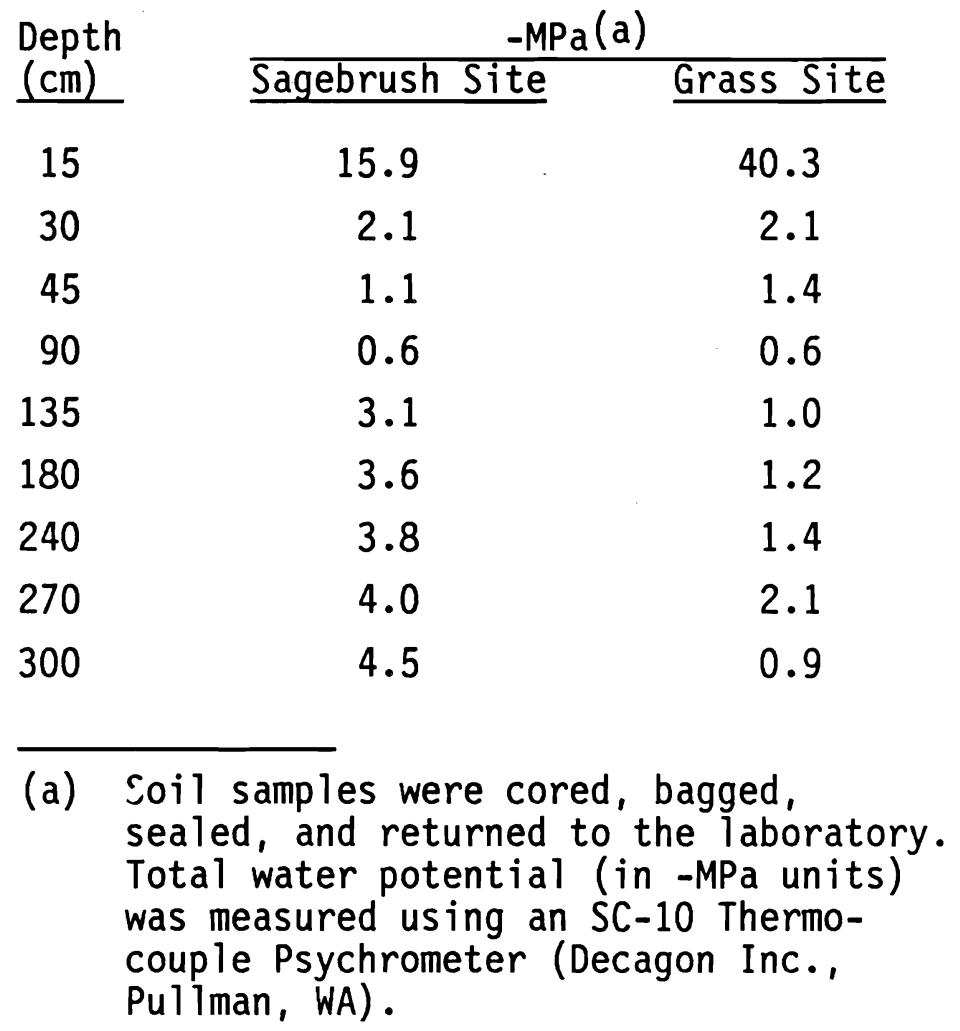


TABLE 4.2. Water Content in Soil Material Taken from Boreholes at the McGee Ranch Site

\begin{tabular}{|c|c|c|c|}
\hline $\begin{array}{l}\text { BOREHOLE } \\
=======\end{array}$ & $\begin{array}{l}\text { DEPTH }(\mathrm{m}) \\
========\end{array}$ & $\begin{array}{l}\text { WATER CONTENT (wt } \%) \\
===============\end{array}$ & $\begin{array}{l}\text { WATER POTENTIAL ( }(-\mathrm{MPa}) \\
================\end{array}$ \\
\hline$\# 33$ & $\begin{array}{l}0.61-0.71 \\
1.52-1.98 \\
3.05-3.51 \\
4.57-5.03 \\
6.10-6.40 \\
7.01-7.32 \\
7.32-7.47 \\
8.08-8.23\end{array}$ & $\begin{array}{l}6.66 \\
7.81 \\
4.25 \\
4.02 \\
2.79 \\
2.12 \\
4.32 \\
3.45\end{array}$ & $\begin{array}{l}3.5 \\
2.0\end{array}$ \\
\hline $\begin{array}{l}\text { BOREHOLE } \\
=======\end{array}$ & $\begin{array}{l}\text { DEPTH (m) } \\
========\end{array}$ & $\begin{array}{l}\text { WATER CONTENT (wt\%) } \\
===============\end{array}$ & $\begin{array}{l}\text { WATER POTENTIAL ( } \\
==========0\end{array}$ \\
\hline$\# 34$ & $\begin{array}{l}0.61-0.71 \\
1.52-1.98 \\
3.05-3.51 \\
4.57-4.88 \\
6.10-6.40 \\
6.40-6.55 \\
7.62-7.77 \\
7.77-8.08 \\
9.14-9.30\end{array}$ & $\begin{array}{l}5.90 \\
8.20 \\
1.88 \\
3.44 \\
1.33 \\
4.72 \\
2.89 \\
4.64 \\
2.19\end{array}$ & 2.0 \\
\hline $\begin{array}{l}\text { BOREHOLE } \\
========\end{array}$ & $\begin{array}{l}\text { DEPTH }(\mathrm{m}) \\
========\end{array}$ & $\begin{array}{l}\text { WATER CONTENT }(w t \%) \\
================\end{array}$ & $\begin{array}{l}\text { WATER POTENTIAL (-MPa) } \\
=================\end{array}$ \\
\hline$\# 35$ & $\begin{array}{l}0.61-0.71 \\
1.52-1.58 \\
1.58-1.83 \\
3.05-3.51 \\
4.57-4.72 \\
4.72-4.88 \\
6.16-6.46 \\
6.46-6.52 \\
7.62-7.92 \\
9.14-9.45\end{array}$ & $\begin{array}{l}6.68 \\
5.21 \\
3.69 \\
3.12 \\
2.34 \\
5.28 \\
1.51 \\
4.03 \\
2.72 \\
1.11\end{array}$ & 1.5 \\
\hline $\begin{array}{l}\text { BOREHOLE } \\
========\end{array}$ & $\begin{array}{l}\text { DEPTH }(\mathrm{m}) \\
========\end{array}$ & $\begin{array}{l}\text { WATER CONTENT }(w t \%) \\
===============\end{array}$ & $\begin{array}{l}\text { WATER POTENTIAL }(-\mathrm{MPa}) \\
===============\end{array}$ \\
\hline$\# 36$ & $\begin{array}{l}0.61-0.71 \\
1.52-1.83 \\
3.05-3.35 \\
4.57-4.88 \\
6.10-6.55 \\
7.62-7.77 \\
7.77-8.08 \\
8.23-8.38\end{array}$ & $\begin{array}{l}5.85 \\
5.21 \\
4.01 \\
3.01 \\
2.36 \\
1.51 \\
3.16 \\
2.97\end{array}$ & 2.5 \\
\hline
\end{tabular}


been initiated, and site-specific, field-saturated hydraulic conductivity values have been obtained at selected locations near a borrow area for soils used in testing protective barrier designs (Adams and Wing 1987). Results of these measurements are included with Grass Site data in the forthcoming report (discussed in Section 4.1) on hydraulic properties for Hanford Site soils. These data will be most useful in predicting the water flow under conditions that may exist near the surface in winter and early spring. However, additional sampling is required to substantiate the dry soil conditions observed at the McGee Ranch site. Lysimeter data would provide such information if the soils were allowed sufficient time to equilibrate in the lysimeter. It should be noted that at these very low drainage rates relatively long times would ensue before equilibrium was reached; hence these rates of flow can be determined only indirectly over a time span of 3 to 5 years.

The fine soils at the McGee Ranch site are very dry at depth, which suggests that plants are effective in removing water from the soils. This cycling of the precipitation water, such that little if any water moves past the root zone for long periods of time, supports the concept that a "cyclic" barrier is feasible given Hanford soil and climate conditions. The engineered barrier is designed to prevent infiltration of water past the root zone and thus to provide a zone of zero recharge for extended periods of time (Adams and Wing 1987). Evidence of this condition at the McGee Ranch site is apparent. It would be very helpful if further quantification of the actual water flow in these fine-grained soils could be documented. The use of tracers such as $3 \mathrm{H}$ and $36 \mathrm{Cl}$ might provide this information.

In summary, the fine soils of the McGee Ranch area, where covered with deep-rooted plants, are dry at depths of $6 \mathrm{~m}$ or more. The flow rates at these low water contents are expected to be less than $0.1 \mathrm{~cm} / \mathrm{yr}$, but measurements are needed for confirmation. Drainage lysimeters or tracer tests may be the most appropriate method for determining flow rates in the dry soils at the McGee Ranch site. 


\subsection{OBSERVATIONS AND CONCLUSIONS}

Based on the results of lysimeter and field tests to date, recharge rates for specific locations at the Hanford Site can vary from zero to more than the average annual precipitation depending on which of many factors, or combination of factors, operates to control the water balance at a given site. The 200 Area deep-lysimeter is not draining and has stayed "dry" during the same period of time that 15 lysimeters in the 300 Area have drained readily. The difference apparently is that the 200 Area lysimeter has been covered with vegetation, while those in the 300 Area, with one exception, have not. Bare soils have consistently drained in the 300 Area. The 300 Area Grass Site data suggest that recharge is occurring; in contrast, the site at McGee Ranch indicates that little water movement, if any, is occurring below the root zone.

The differences in drainage observed in the lysimeters largely result from differences in plant cover. Lysimeters with plant cover have less measured drainage than those that are bare (i.e., have no plant cover). The difference in recharge at undisturbed sites apparently results from a combination of finer soil texture and difference in vegetation (shallow-rooted plants at the Grass Site compared to deep-rooted plants at McGee Ranch). Figure 5.1 shows the water retention characteristics for soils at the 200 Area deep lysimeter, the 300 Area BWTF, and the McGee Ranch site. The data indicate that the water storage capacity of McGee Ranch soil is considerably greater than that of the 200 Area and 300 Area lysimeter soils. That the soil has dried out over time at McGee Ranch suggests that, with present climate conditions, the soil water is not draining at this site and the annual winter rains, which tend to drain through coarse surface soils, are being retained in the near surface where they are recycled by ET processes. The data further suggest that water uptake by deep roots has dried subsurface soils to the extent that little liquid water movement is occurring below the root zone in the fine soils. This suggestion supports the hypothesis currently being tested in the Protective Barriers Program (Adams and Wing 1987): Fine-textured soil placed at the surface of a waste site reduces the potential for drainage.

When gravel is placed on the surface, significant increase in water infiltration and storage occurs. Much of the annual precipitation may be captured 


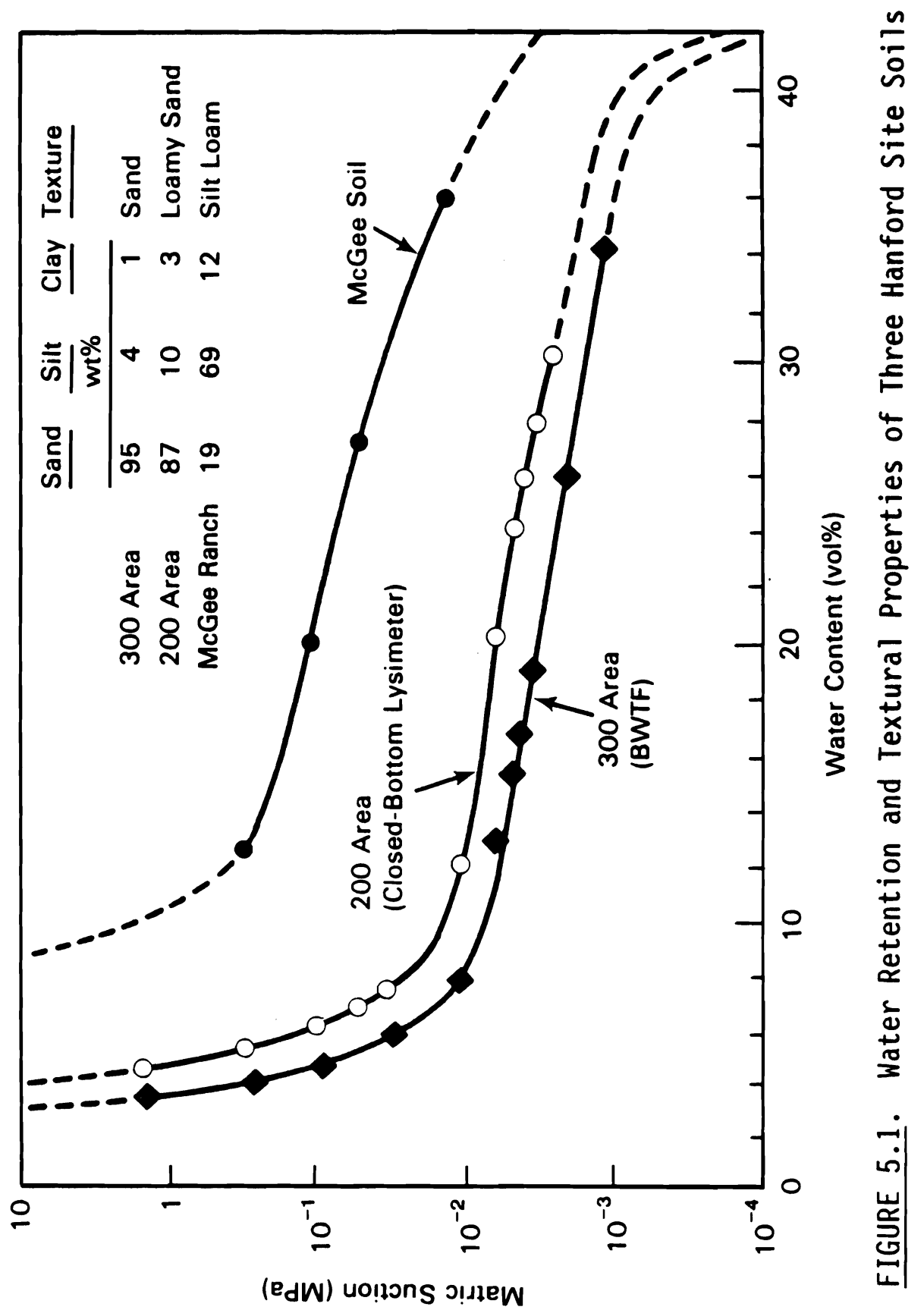


by the rock-covered soil. The drainage observed at the Grout Waste Test Facility (discussed in Section 3.3) clearly is different than at the 200 Area lysimeter or at the McGee Ranch site. However, in areas where gravels cover the surface, such as at tank farm sites, most of the annual precipitation can be expected to drain through the gravel and be available for recharge.

Based on the data analyzed during the past 3 years, the following conclusions can be made:

1. Twelve drainage lysimeters located in the 300 Area have provided evidence that more than half of the annual precipitation could drain to the water table at this location when soils are coarse-textured and bare and when meteorological conditions are similar to those that existed when the lysimeters were tested.

2. Model-derived estimates of recharge for the Hanford Site should consider all factors affecting recharge. To date, detailed information gathered has been insufficient to predict recharge accurately for specific sites. Simplified models that require only climatic input or generalized soil and plant data and use monthly averages may underestimate the drainage. The UNSAT-H model is the best model currently available for predicting drainage at waste sites at Hanford. It is a deterministic code that calculates drainage as well as evaporation on an hourly or smaller time-step interval.

3. Hydraulic gradient measurements provide estimates of the direction of water flow. Hydraulic conductivity data provide qualitative information that is useful for scoping analyses, but order-of-magnitude calculations are probably the best that can be obtained from this of type analysis. At the SC lysimeter, a unit-gradient condition has been obtained, and the mean hydraulic conductivity at 11 vol\% water content is about $10 \mathrm{~cm} / \mathrm{yr}\left(3.2 \times 10^{-7} \mathrm{~cm} / \mathrm{s}\right)$.

4. An understanding of plant-water relations is needed to predict recharge. Current models use inadequate data for rooting depth and other plant characteristics that control water loss. Additional time will be required to obtain the appropriate data to quantify plant response to soil and climate variables at the Hanford Site. It is 
a worthy goal, however, because plants have been shown to virtually control the fate of surface water. When deep-rooted plants are present, even relatively coarse soils show little evidence of downward drainage. When plants are absent, drainage occurs (as much as $10 \mathrm{~cm} / \mathrm{yr}$ ) for coarse-textured soils under present climate conditions (average of $\sim 16 \mathrm{~cm} / \mathrm{yr}$ precipitation).

5. Fine-textured soils tend to hold more water and are preferred for use as soil cover over waste sites rather than using coarse-textured soils or gravel. Gravel surfaces may trap water causing much of the annual precipitation to drain to the water table. 


\subsection{REFERENCES}

Adams, M. R., and N. R. Wing. 1987. Protective Barrier and Warning Marker System Development Plan. RHO-RE-PL-35P, Rockwell Hanford Operations, Richland, Washington.

Bauer, H. H., and J. J. Vaccaro. 1986. "Model Estimates of Climatological Variability on Ground-Water Recharge." In Conference on Climate and Water Management - A Critical Era, Asheville, North Carolina, August 4-7, 1986, pp. 45-48. American Meteorological Society, Boston, Massachusetts.

Bauer, H. H., and J. J. Vaccaro. 1987. Documentation of the Deep Percolation Model for Ground-Water Recharge. Open File Report 86-536, U.S. Geological Survey, Seattle, Washington.

Cline, J. F., D. W. Ursek and W. H. Rickard. 1977. "Comparison of Soil Water Used by Sagebrush-Bunchgrass and Cheatgrass Community." J. Range Manage. 30:199-201.

DOE. See U.S. Department of Energy.

Dove, F. H., C. R. Cole, M. G. Foley, F. W. Bond, R. E. Brown, W. J. Deutsch, M. D. Freshley, S. K. Gupta, P. J. Gutknecht, W. L. Kuhn, J. W. Lindberg, W. A. Rice, R. Schalla, J. F. Washburn and J. T. Zellmer. 1982. AEGIS Technology Demonstration for a Nuclear Waste Repository in Basalt. PNL-3632, Pacific Northwest Laboratory, Richland, Washington.

ERDA. See U.S. Energy Research and Development Administration.

Fayer, M. J. 1987. Model Assessment of Protective Barrier Designs: Part II. PNL-6297, Pacific Northwest Laboratory, Richland, Washington.

Fayer, M. J., G. W. Gee and T. L. Jones. 1986. UNSAT-H Version 1.0: Unsaturated Flow Code Documentation and Applications for the Hanford Site. PNL-5899, Pacific Northwest Laboratory, Richland, Washington.

Fayer, M. J., W. Conbere, P. R. Heller and G. W. Gee. 1985. Model Assessment of Protective Barrier Designs. PNL-5604, Pacific Northwest Laboratory, Richland, Washington.

Foote, H. P., S. C. Blair, G. E. Wukelic and V. L. Coburn. 1980. Evaluation of Growth in Irrigated Agriculture in the Columbia Plateau 1975-1979. RHO-BWI-C-97/PNL-3783. Rockwe11 Hanford Operations and Pacific Northwest Laboratory, Richland, Washington.

Freeze, R. A., and J. A. Cherry. 1979. Groundwater. Prentice-Hall, Englewood Cliffs, New Jersey.

Gee, G. W., and P. R. Heller. 1985. Unsaturated Water Flow at the Hanford Site: A Review of the Literature and Annotated Bibliography. PNL-5428, Pacific Northwest Laboratory, Richland, Washington. 
Gee, G. W., and T. L. Jones. 1985. Lysimeters at the Hanford Site: Present Use and Future Needs. PNL-5578, Pacific Northwest Laboratory, Richland, Washington.

Gee, G. W., and R. R. Kirkham. 1984. Arid Site Water Balance - Evapotranspiration Modeling and Measurements. PNL-5177, Pacific Northwest Laboratory, Richland, Washington.

Gutknecht, P. J., W. A. Rice, C. R. Cole and M. D. Freshley. 1980. Pasco Basin Hydrometeorological Study. RHO-BWI-C-98/PNL-3855, Rockwell Hanford Operations, Richland, Washington.

Hajek, B. F. 1966. Soil Survey, Hanford Project in Benton County, Washington. BNWL-243, Pacific Northwest Laboratory, Richland, Washington.

Hsieh, J. J. C., L. E. Brownell and A. E. Reisenauer. 1973. Lysimeter Experiment, Description and Progress Report on Neutron Measurements. BNWL-1711, Pacific Northwest Laboratory, Richland, Washington.

Jones, T. L. 1978. Sediment Moisture Relations: Lysimeter Project 1967-1977 Water Years. RHO-ST-15, Rockwell Hanford Operations, Richland, Washington.

Jones, T. L., and R. L. Skaggs. 1987. "Influence of Hydrologic Factors on Leaching of Solidified Low-Level Waste Forms at an Arid Site Field-Scale Lysimeter Facility." PNL-SA-14908, Pacific Northwest Laboratory, Richland, Washington. Presented at the 4th International Hazardous Waste Symposium on Environmental Aspects of Stabilization/Solidification of Hazardous and Radioactive Wastes, Atlanta, Georgia, May 3-6, 1987.

Jones, T. L., G. W. Gee and G. S. Campbell. 1984. Water Balance at an Arid Site: A Model Validation Study of Bare Soil Evaporation. PNL-4896, Pacific Northwest Laboratory, Richland, Washington.

Last, G. V., P. G. Easley and D. J. Brown. 1976. Soil Moisture Transport During the 1974-1975 and 1975-1976 Water Years. ARH-ST-146, Atlantic Richfield Hanford Company, Richland, Washington.

Last, G. V., M. A. Glennon, M. A. Young and G. W. Gee. 1987. Protective Barrier Materials Analysis: Fine Soil Site Characterization. PNL-6314, Pacific Northwest Laboratory, Richland, Washington.

Morton, F. I. 1975. "Estimating Evaporation and Transpiration from Climatological Observations." J. App1. Meteorol. 14(4):488-497.

Morton, F. I. 1976. "Climatological Estimates of Evapotranspiration." Paper 11974. Proc. ASCE, J. Hydraul. Div. 102(HY3):275-290.

Morton, F. I. 1978. "Estimating Evaporation from Potential Evaporation: Practicality of an Iconoclastic Approach." J. Hydrol. 38:1-32. 
Morton, F. I. 1983. "Operational Estimates of Areal Evapotranspiration and Their Significance to the Science and Practice of Hydrology." J. Hydrol. 66:1-76.

National Academy of Sciences. 1978. Radioactive Wastes at the Hanford Reservation. A Technical Review. Panel on Hanford Wastes. National Academy of Sciences, Washington, D.C.

Penman, H. L. 1948. "Natural Evaporation from Open Water, Bare Soil and Grass." Proc. R. Soc. Lond. A 193:120-146.

Phillips, S. J., A. C. Campbe11, M. D. Campbe11, G. W. Gee, H. H. Hoober and K. 0. Schwarzmiller. 1979. A Field Test Facility for Monitoring Water/Radionuclide Transport Through Partially Saturated Geologic Media: Design, Construction, and Preliminary Description. PNL-3226, Pacific Northwest Laboratory, Richland, Washington.

Saxton, K. E., H. P. Johnson and R. H. Shaw. 1974. "Modeling Evapotranspiration and Soil Moisture." Trans. ASCE 17:673-677.

Simmons, C. S., and G. W. Gee. 1981. Simulation of Water Flow and Retention in Earthen Cover Materials Overlying Uranium Mill Tailing. UMT/0203/PNL3877, Pacific Northwest Laboratory, Richland, Washington.

Stone, W. A., J. M. Thorp, 0. P. Gifford, and D. J. Hoitink. 1983. Climatological Summary for the Hanford Area. PNL-4622, Pacific Northwest Laboratory, Richland, Washington.

Thornthwaite, C. W., and J. R. Mather. 1955. "The Water Balance." Publications in Climatology $8(1)$, Laboratory of Climatology, Centerton, New Jersey.

U.S. Department of Agriculture (USDA). 1973. Irrigation Guide for the Columbia Basin. Soil Conservation Service, Spokane, Washington.

U.S. Department of Energy (DOE). 1986. Draft Environmental Impact Statement. Disposal of Hanford Defense High Level, Transuranic and Tank Wastes at Hanford Site. Vol. 1. D0E/EIS-0113, U.S Department of Energy, Washington, D.C.

U.S. Energy Research and Development Administration (ERDA). 1975. Final Environmental Statement, Waste Management Operations, Hanford Reservation, Richland, Washington. Vols. 1 and 2. ERDA-1538, National Technical Information Service, Springfield, Virginia.

Wallace, R. W. 1978. A Comparison of Evapotranspiration Estimates Using DOE Hanford Climatological Data. PNL-2698, Pacific Northwest Laboratory, Richland, Washington.

Walter, M. B., M. J. Graham and G. W. Gee. 1984. A Field Lysimeter Facility for Evaluating the Performance of Commercial Solidified Low-Level Waste. PNL-5253, Pacific Northwest Laboratory, Richland, Washington. 
Whelan, G., D. L. Strenge, J. G. Droppo, Jr., B. L. Steelman and J. W. Buck. 1987. The Remedial Action Priority System (RAPS): Mathematical Formulations. PNL-6200, Pacific Northwest Laboratory, Richland, Washington.

Wight, J. R., and E. L. Neff. 1983. Soil-Vegetation Hydrology Studies, Vol. II. A User Manual for ERHYM, U.S. Department of Agriculture, ARA. Agric. Res. Results ARR-W-29:38.

Wukelic, G. E., H. P. Foote, S. C. Blair and C. D. Begej. 1981.

Monitoring Land- and Water-Use Dynamics in the Columbia Plateau Using

Remote-Sensing Computer Analys is and Integration Techniques.

RHO-BW-CR-12201/PNL-4047, Pacific Northwest Laboratory,

Richland, Washington. 


\section{APPENDIX}

PRECIPITATION AND DRAINAGE DATA FOR THE BURIED WASTE TEST FACILITY (BWTF) AND HANFORD METEROLOGICAL STATION PRECIPITATION DATA 
TABLE A.1. Precipitation Data for the Buried Waste Facility Site (BWTF) Near 300 Area, Hanford Site

PRECIPITATION DATA FOR THE BURIED WASTE TEST FACILITY FROM 1979 TO JUNE 1987

\begin{tabular}{|c|c|c|c|c|c|}
\hline DATE & $\begin{array}{l}\text { DAYS SINCE } \\
31-D E C-78\end{array}$ & $\begin{array}{l}\text { DAY OF } \\
\text { YEAR }\end{array}$ & $\begin{array}{l}\text { PRECIP } \\
(\mathrm{CM})\end{array}$ & $\begin{array}{l}\text { CUMULATIVE } \\
\text { ANNUAL CM }\end{array}$ & $\begin{array}{l}\text { CUMULATIVE } \\
\text { TOTAL CM }\end{array}$ \\
\hline 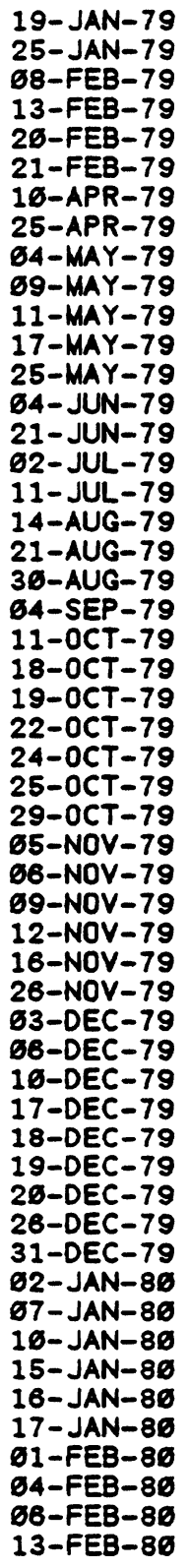 & $\begin{array}{r}19 \\
25 \\
39 \\
44 \\
51 \\
52 \\
169 \\
115 \\
124 \\
129 \\
131 \\
137 \\
145 \\
155 \\
172 \\
183 \\
192 \\
226 \\
233 \\
242 \\
247 \\
284 \\
291 \\
292 \\
295 \\
297 \\
298 \\
362 \\
369 \\
316 \\
313 \\
316 \\
326 \\
330 \\
337 \\
346 \\
344 \\
351 \\
352 \\
353 \\
354 \\
360 \\
365 \\
367 \\
372 \\
375 \\
386 \\
381 \\
382 \\
397 \\
460 \\
462 \\
469\end{array}$ & $\begin{array}{r}19 \\
25 \\
39 \\
44 \\
51 \\
52 \\
160 \\
115 \\
124 \\
129 \\
131 \\
137 \\
145 \\
155 \\
172 \\
183 \\
192 \\
226 \\
233 \\
242 \\
247 \\
284 \\
291 \\
292 \\
295 \\
297 \\
298 \\
362 \\
369 \\
316 \\
313 \\
316 \\
320 \\
336 \\
337 \\
346 \\
344 \\
351 \\
352 \\
353 \\
354 \\
360 \\
365 \\
2 \\
7 \\
16 \\
15 \\
16 \\
17 \\
32 \\
35 \\
37 \\
44\end{array}$ & 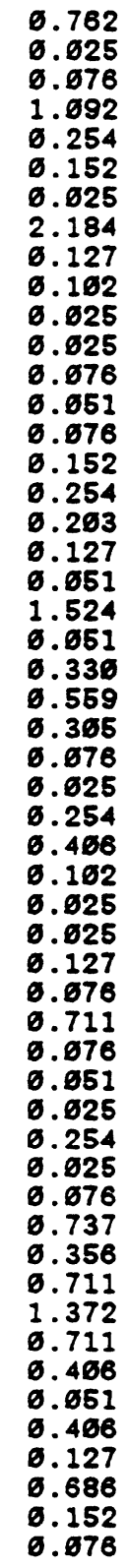 & $\begin{array}{r}6.762 \\
6.787 \\
9.864 \\
1.956 \\
2.216 \\
2.362 \\
2.388 \\
4.572 \\
4.699 \\
4.861 \\
4.826 \\
4.851 \\
4.928 \\
4.978 \\
5.655 \\
5.267 \\
5.461 \\
5.664 \\
5.791 \\
5.842 \\
7.366 \\
7.417 \\
7.747 \\
8.366 \\
8.611 \\
8.687 \\
8.712 \\
8.966 \\
9.373 \\
9.474 \\
9.566 \\
9.525 \\
9.652 \\
9.728 \\
16.439 \\
10.516 \\
10.566 \\
16.592 \\
16.846 \\
16.871 \\
10.947 \\
11.684 \\
12.046 \\
6.711 \\
2.683 \\
2.794 \\
3.260 \\
3.251 \\
3.658 \\
3.785 \\
4.476 \\
4.623 \\
4.699\end{array}$ & $\begin{array}{r}6.762 \\
9.787 \\
9.864 \\
1.956 \\
2.216 \\
2.362 \\
2.388 \\
4.572 \\
4.699 \\
4.861 \\
4.826 \\
4.851 \\
4.928 \\
4.978 \\
5.855 \\
5.267 \\
5.461 \\
5.664 \\
5.791 \\
5.842 \\
7.368 \\
7.417 \\
7.747 \\
8.366 \\
8.611 \\
8.687 \\
8.712 \\
8.966 \\
9.373 \\
9.474 \\
9.566 \\
9.525 \\
9.652 \\
9.728 \\
16.439 \\
16.516 \\
10.566 \\
10.592 \\
10.846 \\
16.871 \\
16.947 \\
11.684 \\
12.846 \\
12.751 \\
14.122 \\
14.834 \\
15.246 \\
15.291 \\
15.697 \\
15.824 \\
16.516 \\
16.662 \\
16.739\end{array}$ \\
\hline
\end{tabular}


TABLE A.1. (cont'd)

PRECIPITATION DATA FOR THE BURIED WASTE TEST FACILITY FROM 1979 TO JUNE 1987

\begin{tabular}{|c|c|c|c|c|c|}
\hline DATE & $\begin{array}{l}\text { DAYS SINCE } \\
31-D E C-78\end{array}$ & $\begin{array}{l}\text { DAY OF } \\
\text { YEAR }\end{array}$ & $\begin{array}{l}\text { PRECIP } \\
\text { (CM) }\end{array}$ & $\begin{array}{l}\text { CUMULATIVE } \\
\text { ANNUAL CM }\end{array}$ & $\begin{array}{l}\text { CUMULATIVE } \\
\text { TOTAL CM }\end{array}$ \\
\hline 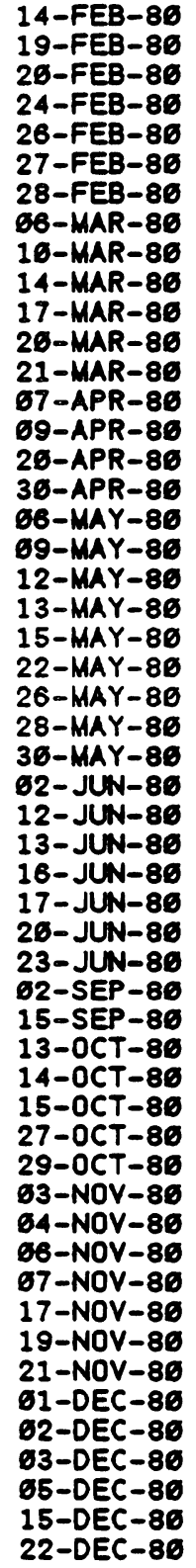 & $\begin{array}{l}416 \\
415 \\
416 \\
426 \\
422 \\
423 \\
424 \\
431 \\
435 \\
439 \\
442 \\
445 \\
446 \\
463 \\
465 \\
476 \\
486 \\
492 \\
495 \\
498 \\
499 \\
561 \\
568 \\
512 \\
514 \\
516 \\
519 \\
529 \\
536 \\
533 \\
534 \\
537 \\
546 \\
611 \\
624 \\
652 \\
653 \\
654 \\
666 \\
668 \\
673 \\
674 \\
676 \\
677 \\
687 \\
689 \\
691 \\
761 \\
762 \\
763 \\
765 \\
715 \\
722\end{array}$ & $\begin{array}{r}45 \\
56 \\
51 \\
55 \\
57 \\
58 \\
59 \\
66 \\
76 \\
74 \\
77 \\
86 \\
81 \\
98 \\
166 \\
111 \\
121 \\
127 \\
136 \\
133 \\
134 \\
136 \\
143 \\
147 \\
149 \\
151 \\
154 \\
164 \\
165 \\
168 \\
169 \\
172 \\
175 \\
246 \\
259 \\
287 \\
288 \\
289 \\
361 \\
363 \\
368 \\
369 \\
311 \\
312 \\
322 \\
324 \\
326 \\
336 \\
337 \\
338 \\
346 \\
356 \\
357\end{array}$ & 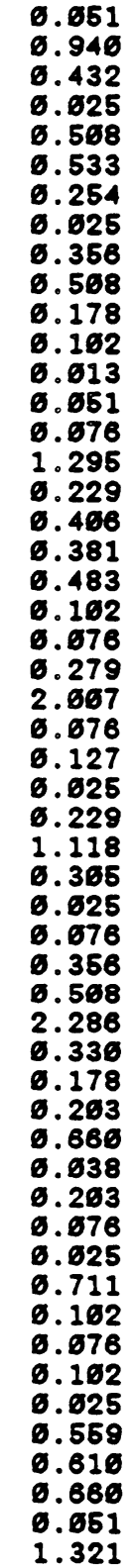 & $\begin{array}{r}4.756 \\
5.696 \\
6.121 \\
6.147 \\
6.655 \\
7.188 \\
7.442 \\
7.468 \\
7.823 \\
8.331 \\
8.569 \\
8.611 \\
8.623 \\
8.674 \\
8.756 \\
16.646 \\
16.274 \\
16.681 \\
11.662 \\
11.544 \\
11.646 \\
11.722 \\
12.662 \\
14.668 \\
14.684 \\
14.211 \\
14.237 \\
14.465 \\
15.583 \\
15.888 \\
15.913 \\
15.989 \\
16.345 \\
16.853 \\
19.139 \\
19.469 \\
19.647 \\
19.856 \\
26.511 \\
26.549 \\
26.752 \\
26.828 \\
26.853 \\
21.565 \\
21.666 \\
21.742 \\
21.844 \\
21.869 \\
22.428 \\
23.638 \\
23.698 \\
23.749 \\
25.676\end{array}$ & $\begin{array}{l}16.789 \\
17.729 \\
18.161 \\
18.186 \\
18.694 \\
19.228 \\
19.482 \\
19.567 \\
19.863 \\
26.371 \\
26.549 \\
26.856 \\
26.663 \\
26.714 \\
26.796 \\
22.685 \\
22.314 \\
22.726 \\
23.161 \\
23.584 \\
23.686 \\
23.762 \\
24.641 \\
26.848 \\
26.124 \\
26.251 \\
26.276 \\
26.565 \\
27.623 \\
27.927 \\
27.953 \\
28.629 \\
28.385 \\
28.893 \\
31.179 \\
31.569 \\
31.687 \\
31.896 \\
32.556 \\
32.588 \\
32.791 \\
32.868 \\
32.893 \\
33.664 \\
33.766 \\
33.782 \\
33.884 \\
33.969 \\
34.468 \\
35.877 \\
35.738 \\
35.789 \\
37.169\end{array}$ \\
\hline
\end{tabular}


TABLE A.1. (cont'd)

PRECIPITATION DATA FOR THE BURIED WASTE TEST FACILITY FROM 1979 TO JUNE 1987

\begin{tabular}{|c|c|c|c|c|c|}
\hline DATE & $\begin{array}{l}\text { DAYS SINCE } \\
31-D E C-78\end{array}$ & $\begin{array}{l}\text { DAY OF } \\
\text { YEAR }\end{array}$ & $\begin{array}{l}\text { PRECIP } \\
(\mathrm{CM})\end{array}$ & $\begin{array}{l}\text { CUMULATIVE } \\
\text { ANNUAL CM }\end{array}$ & $\begin{array}{l}\text { CUMULATIVE } \\
\text { TOTAL CM }\end{array}$ \\
\hline 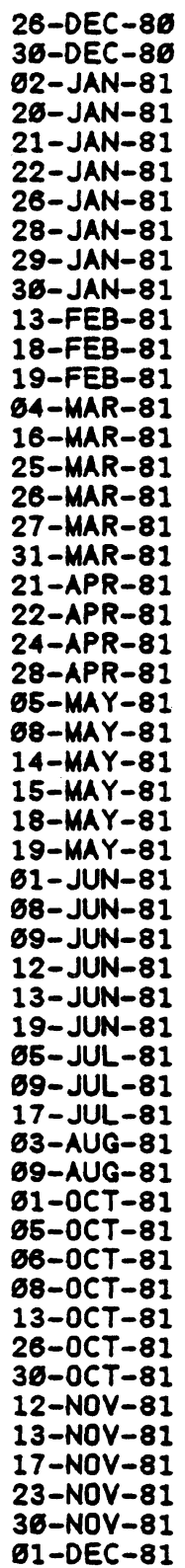 & $\begin{array}{l}726 \\
736 \\
733 \\
751 \\
752 \\
753 \\
757 \\
759 \\
760 \\
761 \\
775 \\
786 \\
781 \\
794 \\
866 \\
815 \\
816 \\
817 \\
821 \\
842 \\
843 \\
845 \\
849 \\
856 \\
859 \\
865 \\
866 \\
869 \\
876 \\
883 \\
896 \\
891 \\
894 \\
895 \\
961 \\
917 \\
921 \\
929 \\
946 \\
952 \\
1685 \\
1689 \\
1816 \\
1612 \\
1617 \\
1630 \\
1634 \\
1647 \\
1648 \\
1652 \\
1858 \\
1665 \\
1866\end{array}$ & $\begin{array}{r}361 \\
365 \\
2 \\
29 \\
21 \\
22 \\
26 \\
28 \\
29 \\
36 \\
44 \\
49 \\
56 \\
63 \\
75 \\
84 \\
85 \\
86 \\
96 \\
111 \\
112 \\
114 \\
118 \\
125 \\
128 \\
134 \\
135 \\
138 \\
139 \\
152 \\
159 \\
166 \\
163 \\
164 \\
176 \\
186 \\
196 \\
198 \\
215 \\
221 \\
274 \\
278 \\
279 \\
281 \\
286 \\
299 \\
363 \\
316 \\
317 \\
321 \\
327 \\
334 \\
335\end{array}$ & 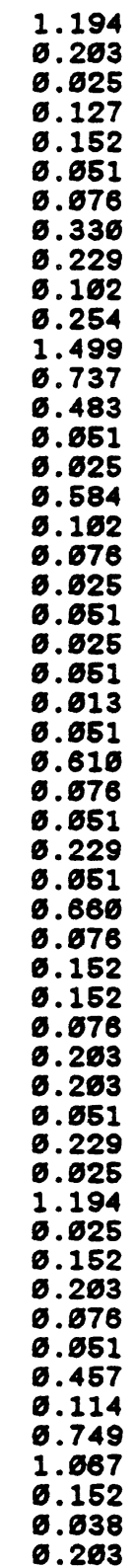 & $\begin{array}{r}26.264 \\
26.467 \\
6.625 \\
9.152 \\
6.365 \\
6.356 \\
6.432 \\
6.762 \\
6.991 \\
1.692 \\
1.346 \\
2.845 \\
3.581 \\
4.664 \\
4.115 \\
4.146 \\
4.724 \\
4.826 \\
4.962 \\
4.928 \\
4.978 \\
5.664 \\
5.655 \\
5.667 \\
5.118 \\
5.728 \\
5.864 \\
5.855 \\
6.683 \\
6.134 \\
6.795 \\
6.871 \\
7.623 \\
7.176 \\
7.252 \\
7.455 \\
7.658 \\
7.769 \\
7.938 \\
7.963 \\
9.157 \\
9.182 \\
9.335 \\
9.538 \\
9.614 \\
9.665 \\
16.122 \\
16.236 \\
16.986 \\
12.652 \\
12.265 \\
12.243 \\
12.446\end{array}$ & $\begin{array}{l}38.363 \\
38.566 \\
38.532 \\
38.659 \\
38.811 \\
38.862 \\
38.938 \\
39.268 \\
39.497 \\
39.599 \\
39.853 \\
41.351 \\
42.688 \\
42.576 \\
42.621 \\
42.647 \\
43.231 \\
43.332 \\
43.469 \\
43.434 \\
43.485 \\
43.510 \\
43.561 \\
43.574 \\
43.625 \\
44.234 \\
44.316 \\
44.361 \\
44.596 \\
44.641 \\
45.361 \\
45.377 \\
45.536 \\
45.682 \\
45.758 \\
45.961 \\
46.165 \\
46.215 \\
46.444 \\
46.469 \\
47.663 \\
47.689 \\
47.841 \\
48.844 \\
48.126 \\
48.171 \\
48.628 \\
48.743 \\
49.492 \\
56.559 \\
56.711 \\
58.749 \\
56.952\end{array}$ \\
\hline
\end{tabular}


TABLE A.1. (cont'd)

PRECIPITATION DATA FOR THE BURIED WASTE TEST FACILITY FROM 1979 TO JUNE 1987

\begin{tabular}{|c|c|c|c|c|c|}
\hline DATE & $\begin{array}{l}\text { DAYS SINCE } \\
31-D E C-78\end{array}$ & $\begin{array}{l}\text { DAY OF } \\
\text { YEAR }\end{array}$ & $\begin{array}{l}\text { PRECIP } \\
(\mathrm{CM})\end{array}$ & $\begin{array}{l}\text { CUMULATIVE } \\
\text { ANNUAL CM }\end{array}$ & $\begin{array}{l}\text { CUMULATIVE } \\
\text { TOTAL CM }\end{array}$ \\
\hline 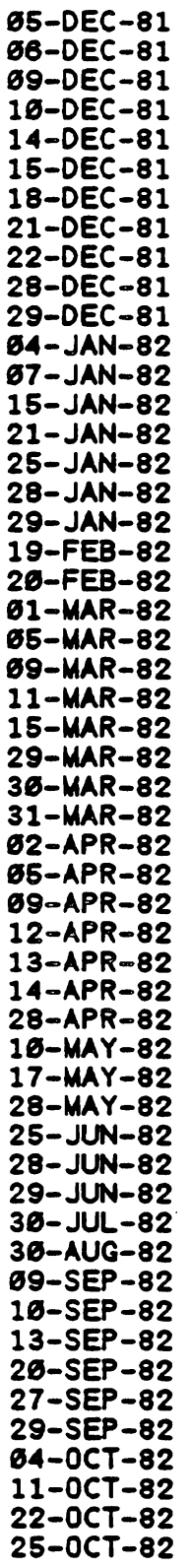 & $\begin{array}{l}1676 \\
1671 \\
1674 \\
1675 \\
1679 \\
1686 \\
1683 \\
1686 \\
1687 \\
1693 \\
1694 \\
1166 \\
1163 \\
1111 \\
1117 \\
1121 \\
1124 \\
1125 \\
1146 \\
1147 \\
1156 \\
1166 \\
1164 \\
1166 \\
1176 \\
1184 \\
1185 \\
1186 \\
1188 \\
1191 \\
1195 \\
1198 \\
1199 \\
1266 \\
1214 \\
1226 \\
1233 \\
1244 \\
1272 \\
1275 \\
1276 \\
1367 \\
1338 \\
1348 \\
1349 \\
1352 \\
1359 \\
1366 \\
1368 \\
1373 \\
1386 \\
1391 \\
1394\end{array}$ & $\begin{array}{r}339 \\
346 \\
343 \\
344 \\
348 \\
349 \\
352 \\
355 \\
356 \\
362 \\
363 \\
4 \\
7 \\
15 \\
21 \\
25 \\
288 \\
29 \\
56 \\
51 \\
66 \\
64 \\
68 \\
76 \\
74 \\
88 \\
89 \\
96 \\
92 \\
95 \\
99 \\
162 \\
183 \\
164 \\
118 \\
136 \\
137 \\
148 \\
176 \\
179 \\
186 \\
211 \\
242 \\
252 \\
253 \\
256 \\
263 \\
276 \\
272 \\
277 \\
284 \\
295 \\
298\end{array}$ & 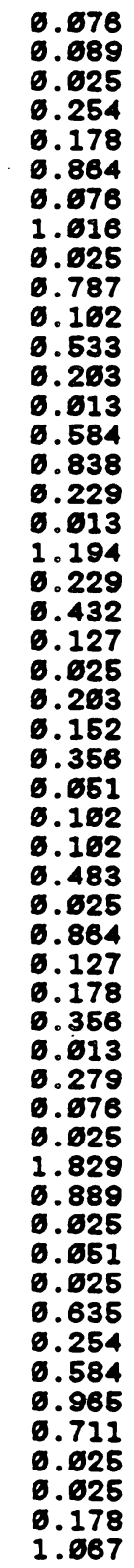 & $\begin{array}{r}12.522 \\
12.611 \\
12.637 \\
12.891 \\
13.668 \\
13.932 \\
14.668 \\
15.624 \\
15.656 \\
15.837 \\
15.939 \\
6.533 \\
6.737 \\
6.749 \\
1.334 \\
2.172 \\
2.466 \\
2.413 \\
3.667 \\
3.835 \\
4.267 \\
4.394 \\
4.426 \\
4.623 \\
4.775 \\
5.131 \\
5.182 \\
5.283 \\
5.385 \\
5.867 \\
5.893 \\
6.756 \\
6.883 \\
7.661 \\
7.417 \\
7.436 \\
7.769 \\
7.785 \\
7.811 \\
9.639 \\
16.528 \\
16.554 \\
10.865 \\
16.630 \\
11.265 \\
11.519 \\
12.163 \\
13.668 \\
13.786 \\
13.865 \\
13.836 \\
14.668 \\
15.675\end{array}$ & $\begin{array}{l}51.629 \\
51.118 \\
51.143 \\
51.397 \\
51.575 \\
52.438 \\
52.515 \\
53.531 \\
53.556 \\
54.343 \\
54.445 \\
54.978 \\
55.182 \\
55.194 \\
55.778 \\
56.617 \\
56.845 \\
56.858 \\
58.852 \\
58.286 \\
58.712 \\
58.839 \\
58.865 \\
59.668 \\
59.226 \\
59.576 \\
59.627 \\
59.728 \\
59.836 \\
66.312 \\
66.338 \\
61.261 \\
61.328 \\
61.586 \\
61.862 \\
61.874 \\
62.154 \\
62.236 \\
62.255 \\
64.684 \\
64.973 \\
64.999 \\
65.849 \\
65.875 \\
65.710 \\
65.964 \\
66.548 \\
67.513 \\
68.224 \\
68.256 \\
68.275 \\
68.453 \\
69.526\end{array}$ \\
\hline
\end{tabular}


TABLE A.1. (cont'd)

PRECIPITATION DATA FOR THE BURIED WASTE TEST FACILITY FROM 1979 TO JUNE 1987

\begin{tabular}{|c|c|c|c|c|c|}
\hline DATE & $\begin{array}{l}\text { DAYS SINCE } \\
31-\text { DEC-78 }\end{array}$ & $\begin{array}{l}\text { DAY OF } \\
\text { YEAR }\end{array}$ & $\begin{array}{l}\text { PRECIP } \\
(C M)\end{array}$ & $\begin{array}{l}\text { CUMULATIVE } \\
\text { ANNUAL CM }\end{array}$ & $\begin{array}{l}\text { CUMULATIVE } \\
\text { TOTAL CM }\end{array}$ \\
\hline 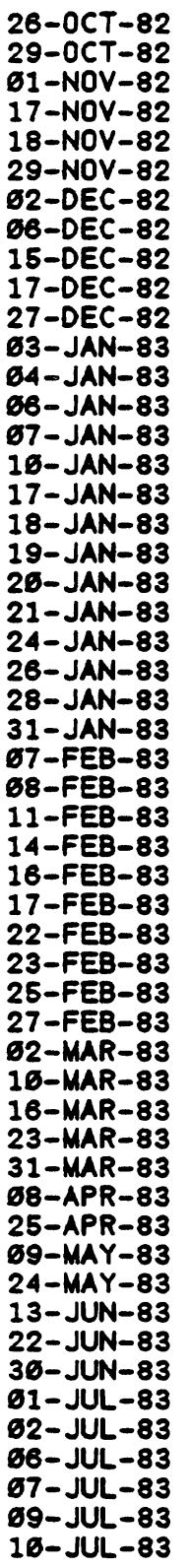 & $\begin{array}{l}1395 \\
1398 \\
1461 \\
1417 \\
1418 \\
1429 \\
1432 \\
1436 \\
1445 \\
1447 \\
1457 \\
1464 \\
1465 \\
1467 \\
1468 \\
1471 \\
1478 \\
1479 \\
1480 \\
1481 \\
1482 \\
1485 \\
1487 \\
1489 \\
1492 \\
1499 \\
1566 \\
1583 \\
1568 \\
1568 \\
1589 \\
1514 \\
1515 \\
1517 \\
1519 \\
1522 \\
1530 \\
1536 \\
1543 \\
1551 \\
1559 \\
1576 \\
1596 \\
1665 \\
1625 \\
1634 \\
1642 \\
1643 \\
1644 \\
1648 \\
1649 \\
1651 \\
1652\end{array}$ & $\begin{array}{r}299 \\
362 \\
365 \\
321 \\
322 \\
333 \\
336 \\
346 \\
349 \\
351 \\
361 \\
3 \\
4 \\
6 \\
7 \\
16 \\
17 \\
18 \\
19 \\
29 \\
21 \\
24 \\
26 \\
28 \\
31 \\
38 \\
39 \\
42 \\
45 \\
47 \\
48 \\
53 \\
54 \\
56 \\
58 \\
61 \\
69 \\
75 \\
82 \\
96 \\
98 \\
115 \\
129 \\
144 \\
164 \\
173 \\
181 \\
182 \\
183 \\
187 \\
188 \\
196 \\
191\end{array}$ & 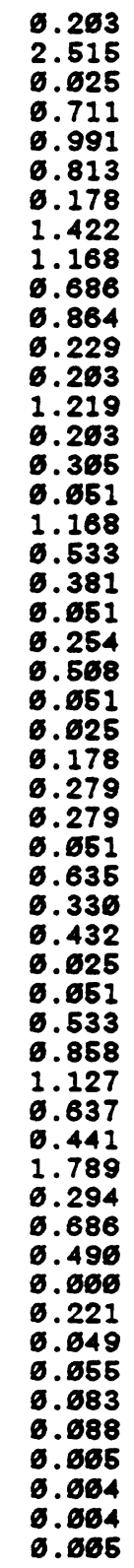 & $\begin{array}{r}15.278 \\
17.793 \\
17.818 \\
18.529 \\
19.526 \\
20.333 \\
26.511 \\
21.933 \\
23.161 \\
23.787 \\
24.651 \\
6.229 \\
6.533 \\
6.737 \\
6.749 \\
1.334 \\
2.172 \\
2.460 \\
2.413 \\
3.667 \\
3.835 \\
4.267 \\
4.394 \\
4.426 \\
4.476 \\
4.496 \\
4.674 \\
4.953 \\
5.232 \\
5.283 \\
5.918 \\
6.248 \\
6.686 \\
6.766 \\
6.756 \\
7.614 \\
8.741 \\
9.378 \\
9.819 \\
11.668 \\
11.962 \\
12.588 \\
13.678 \\
13.678 \\
13.298 \\
13.347 \\
13.462 \\
13.485 \\
13.573 \\
13.578 \\
13.582 \\
13.586 \\
13.591\end{array}$ & $\begin{array}{l}69.723 \\
72.238 \\
72.263 \\
72.974 \\
73.965 \\
74.778 \\
74.955 \\
76.378 \\
77.546 \\
78.232 \\
79.898 \\
79.324 \\
79.527 \\
86.747 \\
86.956 \\
81.255 \\
81.365 \\
82.474 \\
83.667 \\
83.388 \\
83.439 \\
83.693 \\
84.261 \\
84.252 \\
84.277 \\
84.455 \\
84.734 \\
85.814 \\
85.865 \\
85.766 \\
86.636 \\
86.462 \\
86.487 \\
86.538 \\
87.671 \\
87.929 \\
89.856 \\
89.693 \\
96.134 \\
91.923 \\
92.217 \\
92.963 \\
93.393 \\
93.393 \\
93.613 \\
93.662 \\
93.717 \\
93.866 \\
93.888 \\
93.893 \\
93.897 \\
93.961 \\
93.966\end{array}$ \\
\hline
\end{tabular}


TABLE A.1. (cont'd)

PRECIPITATION DATA FOR THE BURIED WASTE TEST FACILITY FROM 1979 TO JUNE 1987

\begin{tabular}{|c|c|c|c|c|c|}
\hline DATE & $\begin{array}{l}\text { DAYS SINCE } \\
31-D E C-78\end{array}$ & $\begin{array}{l}\text { DAY OF } \\
\text { YEAR }\end{array}$ & $\begin{array}{l}\text { PRECIP } \\
\text { (CM) }\end{array}$ & $\begin{array}{l}\text { CUMULATIVE } \\
\text { ANNUAL CM }\end{array}$ & $\begin{array}{l}\text { CUMULATIVE } \\
\text { TOTAL CM }\end{array}$ \\
\hline 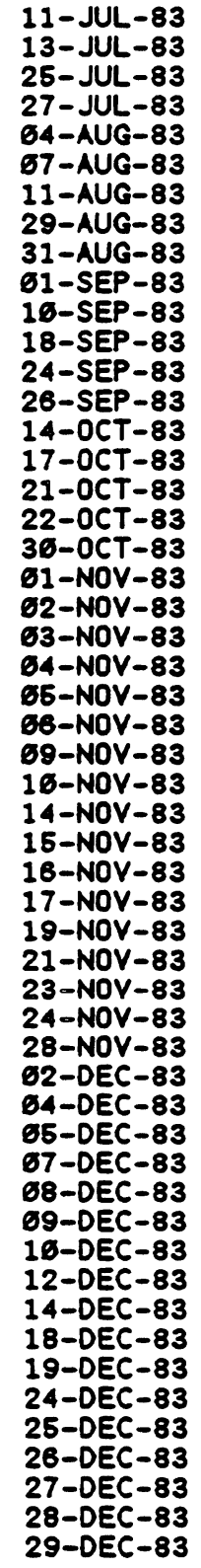 & $\begin{array}{l}1653 \\
1655 \\
1667 \\
1669 \\
1677 \\
1686 \\
1684 \\
1762 \\
1764 \\
1765 \\
1714 \\
1722 \\
1728 \\
1736 \\
1748 \\
1751 \\
1755 \\
1756 \\
1764 \\
1766 \\
1767 \\
1768 \\
1769 \\
1776 \\
1771 \\
1774 \\
1775 \\
1779 \\
1786 \\
1781 \\
1782 \\
1784 \\
1786 \\
1788 \\
1789 \\
1793 \\
1797 \\
1799 \\
1866 \\
1862 \\
1863 \\
1864 \\
1865 \\
1867 \\
1869 \\
1813 \\
1814 \\
1819 \\
1826 \\
1821 \\
1822 \\
1823 \\
1824\end{array}$ & $\begin{array}{l}192 \\
194 \\
266 \\
268 \\
216 \\
219 \\
223 \\
241 \\
243 \\
244 \\
253 \\
261 \\
267 \\
269 \\
287 \\
296 \\
294 \\
295 \\
363 \\
365 \\
366 \\
367 \\
368 \\
369 \\
316 \\
313 \\
314 \\
318 \\
319 \\
326 \\
321 \\
323 \\
325 \\
327 \\
328 \\
332 \\
336 \\
338 \\
339 \\
341 \\
342 \\
343 \\
344 \\
346 \\
348 \\
352 \\
353 \\
358 \\
359 \\
360 \\
361 \\
362 \\
363\end{array}$ & 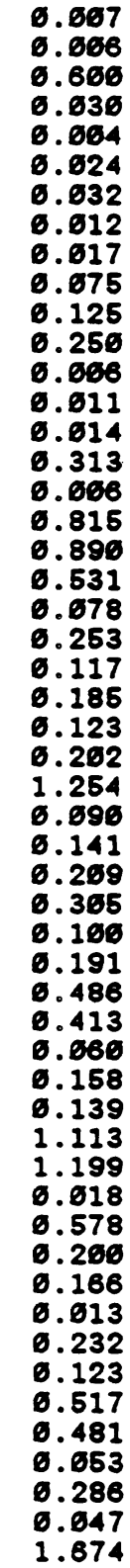 & $\begin{array}{l}13.599 \\
13.665 \\
14.265 \\
14.235 \\
14.239 \\
14.263 \\
14.295 \\
14.367 \\
14.324 \\
14.399 \\
14.525 \\
14.775 \\
14.781 \\
14.792 \\
14.867 \\
15.126 \\
15.126 \\
15.941 \\
16.831 \\
17.363 \\
17.446 \\
17.693 \\
17.869 \\
17.994 \\
18.117 \\
18.319 \\
19.573 \\
19.663 \\
19.863 \\
26.612 \\
26.317 \\
26.417 \\
26.669 \\
21.694 \\
21.568 \\
21.568 \\
21.726 \\
21.864 \\
22.977 \\
24.176 \\
24.194 \\
24.772 \\
24.972 \\
25.139 \\
25.152 \\
25.384 \\
25.567 \\
26.824 \\
26.565 \\
26.558 \\
26.843 \\
26.891 \\
28.565\end{array}$ & $\begin{array}{r}93.913 \\
93.926 \\
94.526 \\
94.556 \\
94.554 \\
94.578 \\
94.616 \\
94.622 \\
94.639 \\
94.714 \\
94.839 \\
95.696 \\
95.896 \\
95.167 \\
95.122 \\
95.435 \\
95.441 \\
96.256 \\
97.146 \\
97.677 \\
97.755 \\
98.667 \\
98.124 \\
98.369 \\
98.432 \\
98.634 \\
99.888 \\
99.977 \\
166.118 \\
166.327 \\
166.632 \\
160.732 \\
160.923 \\
161.469 \\
161.822 \\
161.882 \\
162.646 \\
162.179 \\
163.292 \\
164.491 \\
164.569 \\
165.887 \\
165.287 \\
165.454 \\
165.467 \\
165.698 \\
165.822 \\
166.339 \\
166.826 \\
166.873 \\
167.158 \\
167.286 \\
168.886\end{array}$ \\
\hline
\end{tabular}


TABLE A.1. (cont'd)

PRECIPITATION DRTA FOR THE BURIED WRSTE TEST FACILITY FROM 1979 TO JUNE 1987

\begin{tabular}{|c|c|c|c|c|c|}
\hline DATE & $\begin{array}{l}\text { DAYS SINCE } \\
3 I-D E C-78\end{array}$ & $\begin{array}{l}\text { DAY OF } \\
\text { YEAR }\end{array}$ & $\begin{array}{l}\text { PRECIP } \\
(C M)\end{array}$ & $\begin{array}{l}\text { CUMULATIVE } \\
\text { ANNUAL CM }\end{array}$ & $\begin{array}{l}\text { CUMULATIVE } \\
\text { TOTAL CM }\end{array}$ \\
\hline 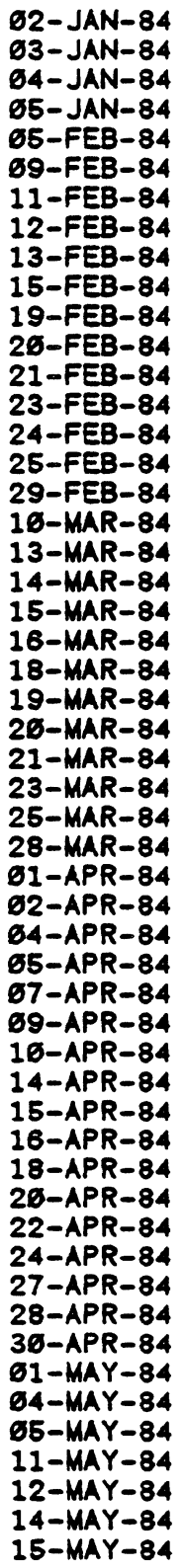 & $\begin{array}{l}1828 \\
1829 \\
1836 \\
1831 \\
1862 \\
1866 \\
1868 \\
1869 \\
1876 \\
1872 \\
1876 \\
1877 \\
1878 \\
1886 \\
1881 \\
1882 \\
1886 \\
1896 \\
1899 \\
1966 \\
1961 \\
1962 \\
1964 \\
1965 \\
1966 \\
1967 \\
1969 \\
1911 \\
1914 \\
1918 \\
1919 \\
1921 \\
1922 \\
1924 \\
1926 \\
1927 \\
1931 \\
1932 \\
1933 \\
1935 \\
1937 \\
1939 \\
1941 \\
1944 \\
1945 \\
1947 \\
1948 \\
1951 \\
1952 \\
1958 \\
1959 \\
1961 \\
1962\end{array}$ & $\begin{array}{r}2 \\
3 \\
4 \\
5 \\
36 \\
46 \\
42 \\
43 \\
44 \\
46 \\
56 \\
51 \\
52 \\
54 \\
55 \\
56 \\
66 \\
76 \\
73 \\
74 \\
75 \\
76 \\
78 \\
79 \\
86 \\
81 \\
83 \\
85 \\
88 \\
92 \\
93 \\
95 \\
96 \\
98 \\
166 \\
161 \\
165 \\
166 \\
167 \\
169 \\
111 \\
113 \\
115 \\
118 \\
119 \\
121 \\
122 \\
125 \\
126 \\
132 \\
133 \\
135 \\
136\end{array}$ & 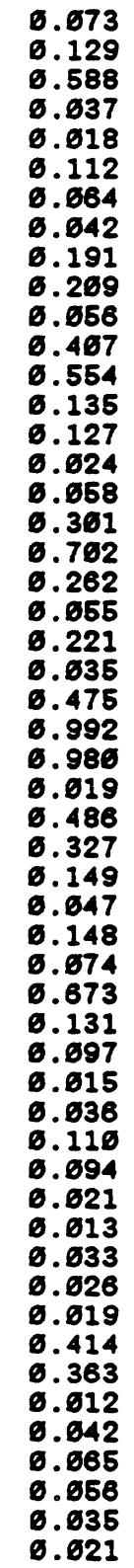 & $\begin{array}{r}6.673 \\
6.262 \\
6.796 \\
6.827 \\
6.845 \\
6.957 \\
1.621 \\
1.663 \\
1.254 \\
1.463 \\
1.519 \\
1.926 \\
2.486 \\
2.615 \\
2.742 \\
2.766 \\
2.824 \\
3.125 \\
3.827 \\
4.689 \\
4.144 \\
4.365 \\
4.461 \\
4.875 \\
5.867 \\
6.848 \\
6.866 \\
7.352 \\
7.679 \\
7.828 \\
7.874 \\
8.623 \\
8.697 \\
8.776 \\
8.961 \\
8.999 \\
9.613 \\
9.649 \\
9.159 \\
9.253 \\
9.273 \\
9.287 \\
9.326 \\
9.346 \\
9.365 \\
9.778 \\
16.141 \\
10.154 \\
16.196 \\
16.261 \\
16.317 \\
16.352 \\
16.373\end{array}$ & 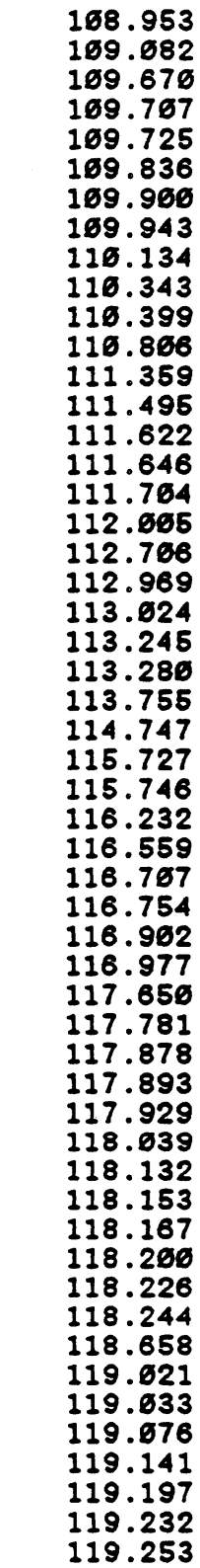 \\
\hline
\end{tabular}


TABLE A.1. (cont'd)

PRECIPITATION DATA FOR THE BURIED K'RSTE TEST FACILITY FROM 1979 TO JUNE 1987

\begin{tabular}{|c|c|c|c|c|c|}
\hline DATE & $\begin{array}{l}\text { DAYS SINCE } \\
31-D E C-78\end{array}$ & $\begin{array}{l}\text { DAY OF } \\
\text { YEAR }\end{array}$ & $\begin{array}{l}\text { PRECIP } \\
(C M)\end{array}$ & $\begin{array}{l}\text { CUMULATIVE } \\
\text { ANNUAL CM }\end{array}$ & $\begin{array}{l}\text { CUMULATIVE } \\
\text { TOTAL CM }\end{array}$ \\
\hline 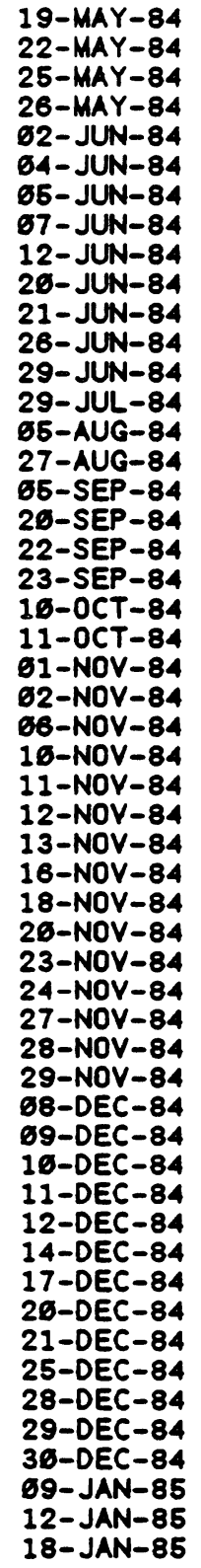 & $\begin{array}{l}1966 \\
1969 \\
1972 \\
1973 \\
1986 \\
1982 \\
1983 \\
1985 \\
1996 \\
1998 \\
1999 \\
2664 \\
2667 \\
2637 \\
2644 \\
2666 \\
2675 \\
2696 \\
2692 \\
2693 \\
2116 \\
2111 \\
2132 \\
2133 \\
2137 \\
2141 \\
2142 \\
2143 \\
2144 \\
2147 \\
2149 \\
2151 \\
2154 \\
2155 \\
2158 \\
2159 \\
2166 \\
2169 \\
2176 \\
2171 \\
2172 \\
2173 \\
2175 \\
2178 \\
2181 \\
2182 \\
2186 \\
2189 \\
2196 \\
2191 \\
2261 \\
2264 \\
2216\end{array}$ & $\begin{array}{r}146 \\
143 \\
146 \\
147 \\
154 \\
156 \\
157 \\
159 \\
164 \\
172 \\
173 \\
178 \\
181 \\
211 \\
218 \\
246 \\
249 \\
264 \\
266 \\
267 \\
284 \\
285 \\
366 \\
367 \\
311 \\
315 \\
316 \\
317 \\
318 \\
321 \\
323 \\
325 \\
328 \\
329 \\
332 \\
333 \\
334 \\
343 \\
344 \\
345 \\
346 \\
347 \\
349 \\
352 \\
355 \\
356 \\
366 \\
363 \\
364 \\
365 \\
99 \\
12 \\
18\end{array}$ & $\begin{array}{l}6.239 \\
6.385 \\
6.146 \\
6.652 \\
6.636 \\
6.868 \\
6.625 \\
6.238 \\
6.631 \\
6.352 \\
6.639 \\
6.161 \\
6.229 \\
6.693 \\
6.656 \\
6.686 \\
6.666 \\
6.175 \\
6.869 \\
6.288 \\
6.155 \\
6.683 \\
6.396 \\
6.378 \\
6.626 \\
6.499 \\
6.243 \\
6.214 \\
6.268 \\
6.668 \\
6.198 \\
6.643 \\
6.827 \\
6.615 \\
1.177 \\
6.196 \\
6.124 \\
6.679 \\
6.948 \\
6.246 \\
6.113 \\
6.216 \\
6.628 \\
6.663 \\
\varnothing .696 \\
6.632 \\
6.626 \\
6.156 \\
6.692 \\
6.623 \\
6.025 \\
6.625 \\
6.625\end{array}$ & $\begin{array}{l}16.612 \\
16.997 \\
11.141 \\
11.193 \\
11.236 \\
12.638 \\
12.663 \\
12.361 \\
12.332 \\
12.684 \\
12.723 \\
12.884 \\
13.114 \\
13.267 \\
13.256 \\
13.323 \\
13.383 \\
13.558 \\
14.367 \\
14.655 \\
14.811 \\
14.893 \\
15.283 \\
15.661 \\
16.681 \\
16.186 \\
16.423 \\
16.637 \\
16.845 \\
16.913 \\
17.112 \\
17.755 \\
18.581 \\
18.597 \\
19.774 \\
19.976 \\
26.695 \\
26.173 \\
21.121 \\
21.367 \\
21.486 \\
21.696 \\
21.724 \\
21.787 \\
21.876 \\
21.968 \\
21.934 \\
22.684 \\
22.776 \\
22.799 \\
6.625 \\
6.651 \\
9.676\end{array}$ & 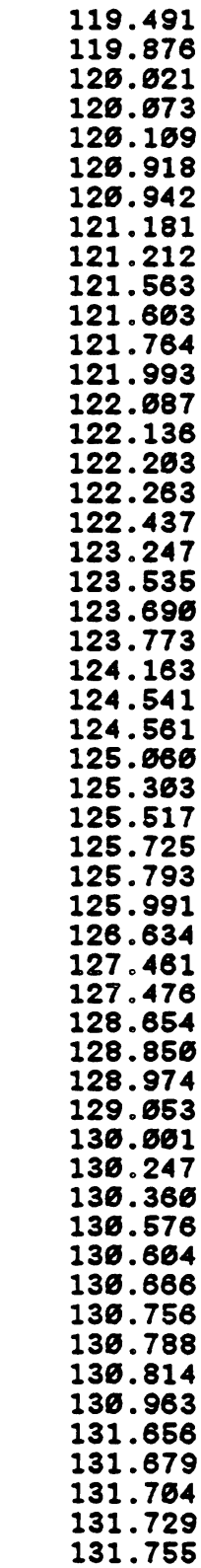 \\
\hline
\end{tabular}


TABLE A.1. (cont'd)

PRECIPITA.TION DATA. FOR THE BURIED WASTE TEST FACILITY FROM 1979 TO JUNE 1987

\begin{tabular}{|c|c|c|c|c|c|}
\hline DATE & $\begin{array}{l}\text { DAYS SINCE } \\
31-D E C-78\end{array}$ & $\begin{array}{l}\text { DAY OF } \\
\text { YEAR }\end{array}$ & $\begin{array}{l}\text { PRECIP } \\
(\mathrm{CM})\end{array}$ & $\begin{array}{l}\text { CUMULATIVE } \\
\text { ANNUAL CM }\end{array}$ & $\begin{array}{l}\text { CUMULATIVE } \\
\text { TOTAL CM }\end{array}$ \\
\hline $\begin{array}{l}20-J A N-85 \\
21-J A N-85 \\
22-J A N-85 \\
62-F E B-85 \\
63-F E B-85 \\
84-F E B-85 \\
65-F E B-85 \\
66-F E B-85 \\
67-F E B-85 \\
68-F E B-85 \\
69-F E B-85 \\
11-F E B-85 \\
12-F E B-85 \\
16-F E B-85 \\
19-F E B-85 \\
23-F E B-85 \\
61-M A R-85 \\
64-M A R-85 \\
26-M A R-85 \\
23-M A R-85 \\
26-M A R-85 \\
27-M A R-85 \\
36-M A R-85 \\
16-A P R-85 \\
22-A P R-85 \\
23-A P R-85 \\
13-M A Y-85 \\
23-M A Y-85 \\
29-M A Y-85 \\
66-J U N-85 \\
67-J U N-85 \\
31-J U L-85 \\
61-A U G-85 \\
62-A U G-85 \\
64-A U G-85 \\
68-S E P-85 \\
69-S E P-85 \\
16-S E P-85 \\
11-S E P-85 \\
12-S E P-85 \\
13-S E P-85 \\
16-S E P-85 \\
17-S E P-85 \\
9\end{array}$ & $\begin{array}{l}2212 \\
2213 \\
2214 \\
2225 \\
2226 \\
2227 \\
2228 \\
2229 \\
2236 \\
2231 \\
2232 \\
2234 \\
2235 \\
2239 \\
2242 \\
2246 \\
2252 \\
2255 \\
2271 \\
2274 \\
2277 \\
2278 \\
2281 \\
2298 \\
2364 \\
2365 \\
2325 \\
2335 \\
2341 \\
2349 \\
2356 \\
2464 \\
2465 \\
2468 \\
2468 \\
2443 \\
2444 \\
2445 \\
2446 \\
2447 \\
2448 \\
2451 \\
2452 \\
2475 \\
2487 \\
2489 \\
2586 \\
2565 \\
2568 \\
2511 \\
2513 \\
2515 \\
2516\end{array}$ & $\begin{array}{r}20 \\
21 \\
22 \\
33 \\
34 \\
35 \\
36 \\
37 \\
38 \\
39 \\
46 \\
42 \\
43 \\
17 \\
56 \\
54 \\
66 \\
63 \\
79 \\
82 \\
85 \\
86 \\
89 \\
166 \\
112 \\
113 \\
133 \\
143 \\
149 \\
157 \\
158 \\
212 \\
213 \\
214 \\
216 \\
251 \\
252 \\
253 \\
254 \\
255 \\
256 \\
259 \\
266 \\
283 \\
295 \\
297 \\
368 \\
313 \\
314 \\
319 \\
321 \\
323 \\
324\end{array}$ & 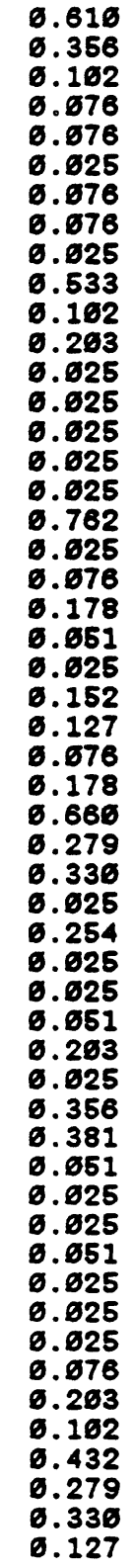 & $\begin{array}{l}6.686 \\
1.841 \\
1.143 \\
1.219 \\
1.295 \\
1.321 \\
1.397 \\
1.473 \\
1.499 \\
2.832 \\
2.134 \\
2.337 \\
2.362 \\
2.388 \\
2.413 \\
2.438 \\
2.464 \\
3.226 \\
3.251 \\
3.327 \\
3.565 \\
3.556 \\
3.581 \\
3.734 \\
3.861 \\
3.937 \\
4.115 \\
4.775 \\
5.655 \\
5.385 \\
5.416 \\
5.664 \\
5.696 \\
5.715 \\
5.766 \\
5.969 \\
5.994 \\
6.356 \\
6.731 \\
6.782 \\
6.867 \\
6.833 \\
6.883 \\
6.969 \\
6.934 \\
6.966 \\
7.636 \\
7.239 \\
7.341 \\
7.772 \\
8.652 \\
8.382 \\
8.569\end{array}$ & $\begin{array}{l}132.364 \\
132.726 \\
132.822 \\
132.898 \\
132.974 \\
132.999 \\
133.676 \\
133.152 \\
133.177 \\
133.711 \\
133.812 \\
134.615 \\
134.641 \\
134.666 \\
134.692 \\
134.117 \\
134.142 \\
134.964 \\
134.936 \\
135.686 \\
135.184 \\
135.235 \\
135.266 \\
135.412 \\
135.539 \\
135.616 \\
135.793 \\
136.454 \\
136.733 \\
137.663 \\
137.689 \\
137.343 \\
137.368 \\
137.394 \\
137.444 \\
137.648 \\
137.673 \\
138.629 \\
138.416 \\
138.466 \\
138.486 \\
138.511 \\
138.562 \\
138.587 \\
138.613 \\
138.638 \\
138.714 \\
138.918 \\
139.819 \\
139.451 \\
139.736 \\
146 . .681 \\
146.188\end{array}$ \\
\hline
\end{tabular}


TABLE A.1. (cont'd)

PRECIPITATION DRTA FOR THE BURIED WASTE TEST FACILITY

FROM 1979 TO JUNE 1987

\begin{tabular}{|c|c|c|c|c|c|}
\hline ATE & $\begin{array}{l}\text { DAYS SINCE } \\
31-D E C-78\end{array}$ & $\begin{array}{l}\text { DAY OF } \\
\text { YEAR }\end{array}$ & $\begin{array}{l}\text { PRECIP } \\
\text { (CM) }\end{array}$ & $\begin{array}{l}\text { CUMULATIVE } \\
\text { ANNUAL CM }\end{array}$ & $\begin{array}{l}\text { CUMULATIVE } \\
\text { TOTAL CM }\end{array}$ \\
\hline $\begin{array}{l}21-N O V-85 \\
22-N O V-85 \\
25-N O V-85 \\
27-N O V-85 \\
29-N O V-85 \\
36-N O V-85 \\
61-D E C-85 \\
62-D E C-85 \\
66-D E C-85 \\
67-D E C-85 \\
24-D E C-85 \\
61-J A N-86 \\
63-J A N-86 \\
65-J A N-86 \\
68-J A N-86 \\
69-J A N-86 \\
15-J A N-86 \\
16-J A N-86 \\
17-J A N-86 \\
18-J A N-86 \\
19-J A N-86 \\
22-J A N-86 \\
23-J A N-86 \\
27-J A N-86 \\
28-J A N-86 \\
29-J A N-86 \\
36-J A N-86 \\
61-F E B-86 \\
62-F E B-86 \\
\text { 63-FEB-86 } \\
64-F E B-86 \\
65-F E B-86 \\
12-F E B-86 \\
15-F E B-86 \\
21-F E B-86 \\
23-F E B-86 \\
67-M A R-86 \\
\text { 68-MAR-86 } \\
69-M A R-86 \\
16-M A R-86 \\
12-M A R-86 \\
13-M A R-86 \\
14-M A R-86 \\
18-M A R-86 \\
23-M A R-86 \\
24-M A R-86 \\
26-M A R-86 \\
36-M A R-86 \\
12-A P R-86 \\
13-A P R-86 \\
26-A P R-86 \\
62-M A Y-86 \\
63-M A Y-86\end{array}$ & $\begin{array}{l}2517 \\
2518 \\
2521 \\
2523 \\
2525 \\
2526 \\
2527 \\
2528 \\
2532 \\
2533 \\
2556 \\
2558 \\
2566 \\
2562 \\
2565 \\
2566 \\
2572 \\
2573 \\
2574 \\
2575 \\
2576 \\
2579 \\
2586 \\
2584 \\
2585 \\
2586 \\
2587 \\
2589 \\
2596 \\
2591 \\
2592 \\
2593 \\
2666 \\
2663 \\
2669 \\
2611 \\
2623 \\
2624 \\
2625 \\
2626 \\
2628 \\
2629 \\
2636 \\
2634 \\
2639 \\
2646 \\
2642 \\
2646 \\
2659 \\
2686 \\
2673 \\
2679 \\
2686\end{array}$ & $\begin{array}{r}325 \\
326 \\
329 \\
331 \\
333 \\
334 \\
335 \\
336 \\
346 \\
341 \\
358 \\
1 \\
3 \\
5 \\
8 \\
9 \\
15 \\
16 \\
17 \\
18 \\
19 \\
22 \\
23 \\
27 \\
28 \\
29 \\
36 \\
32 \\
33 \\
34 \\
35 \\
36 \\
43 \\
46 \\
52 \\
54 \\
66 \\
67 \\
68 \\
69 \\
71 \\
72 \\
73 \\
77 \\
82 \\
83 \\
85 \\
89 \\
162 \\
163 \\
116 \\
122 \\
123\end{array}$ & 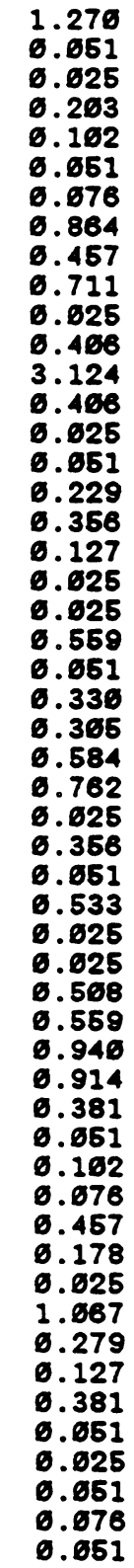 & $\begin{array}{r}9.779 \\
9.836 \\
9.855 \\
16.658 \\
16.166 \\
16.211 \\
16.287 \\
11.151 \\
11.668 \\
12.319 \\
12.344 \\
6.468 \\
3.531 \\
3.937 \\
3.962 \\
4.613 \\
4.242 \\
4.597 \\
4.724 \\
4.756 \\
4.775 \\
5.334 \\
5.385 \\
5.715 \\
6.626 \\
6.664 \\
7.366 \\
7.391 \\
7.747 \\
7.798 \\
8.331 \\
8.357 \\
8.382 \\
8.896 \\
9.449 \\
16.389 \\
11.363 \\
11.684 \\
11.735 \\
11.836 \\
11.913 \\
12.376 \\
12.548 \\
12.573 \\
13.646 \\
13.919 \\
14.646 \\
14.427 \\
14.478 \\
14.563 \\
14.554 \\
14.636 \\
14.681\end{array}$ & $\begin{array}{l}141.458 \\
141.568 \\
141.534 \\
141.737 \\
141.839 \\
141.889 \\
141.966 \\
142.829 \\
143.286 \\
143.998 \\
144.823 \\
144.429 \\
147.554 \\
147.966 \\
147.985 \\
148.636 \\
148.265 \\
148.626 \\
148.747 \\
148.773 \\
148.798 \\
149.357 \\
149.468 \\
149.738 \\
156.643 \\
156.627 \\
151.389 \\
151.414 \\
151.776 \\
151.821 \\
152.354 \\
152.386 \\
152.465 \\
152.913 \\
153.472 \\
154.412 \\
155.326 \\
155.767 \\
155.758 \\
155.859 \\
155.936 \\
156.393 \\
156.571 \\
156.596 \\
157.663 \\
157.942 \\
158.869 \\
158.456 \\
158.561 \\
158.526 \\
158.577 \\
158.653 \\
158.764\end{array}$ \\
\hline
\end{tabular}


TABLE A.1. (cont'd)

PRECIPITATION DATA FOR THE BURIED WASTE TEST FRCILITY

FROM 1979 TO JUNE 1987

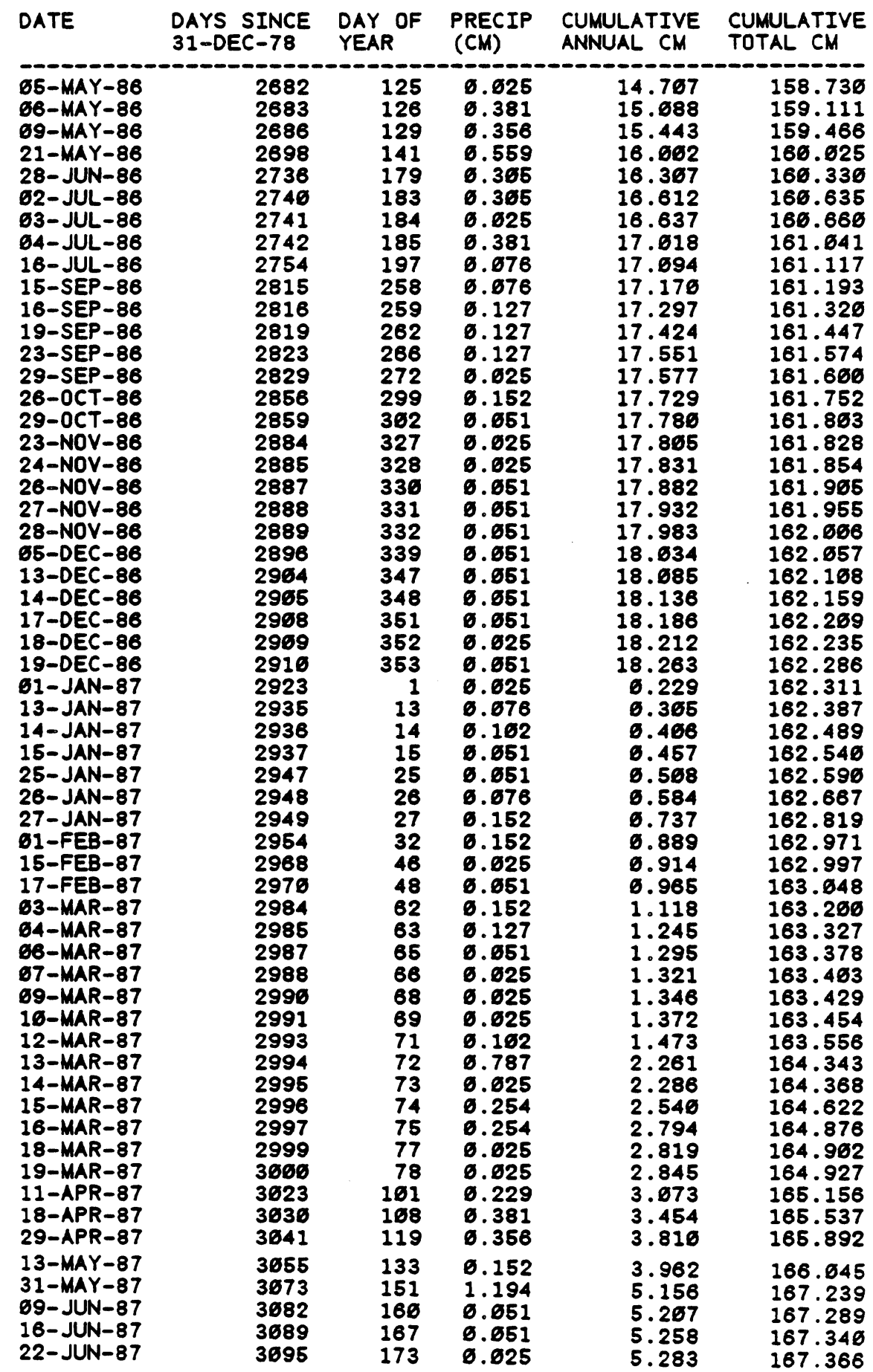


TABLE A.2. Precipitation Data for Hanford Meteorology Station

\begin{tabular}{|c|c|c|c|c|c|}
\hline DATE & $\begin{array}{l}\text { DAYS SINCE } \\
\text { פI-JAN-79 }\end{array}$ & $\begin{array}{l}\text { DAY OF } \\
\text { YEAR }\end{array}$ & $\begin{array}{l}\text { PRECIP } \\
(\mathrm{CM})\end{array}$ & $\begin{array}{l}\text { CUMULATIVE } \\
\text { ANNUAL CM }\end{array}$ & $\begin{array}{l}\text { CUMULATIVE } \\
\text { TOTAL CM }\end{array}$ \\
\hline 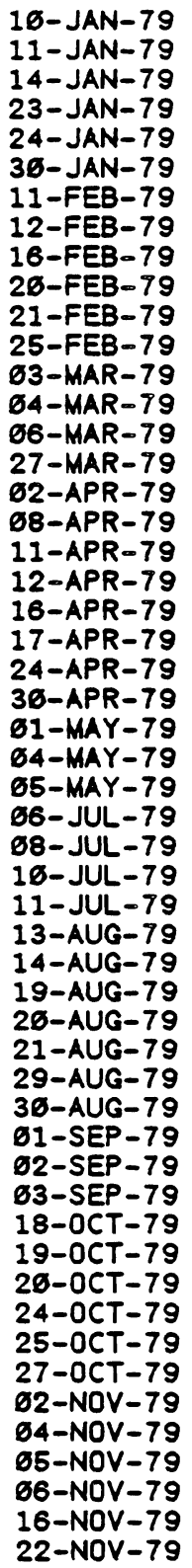 & $\begin{array}{l}1 \emptyset \\
11 \\
14 \\
23 \\
24 \\
36 \\
42 \\
43 \\
47 \\
51 \\
52 \\
56 \\
62 \\
63 \\
65 \\
86 \\
92 \\
98 \\
161 \\
162 \\
166 \\
167 \\
114 \\
126 \\
121 \\
124 \\
125 \\
187 \\
189 \\
191 \\
192 \\
225 \\
226 \\
231 \\
232 \\
233 \\
241 \\
242 \\
244 \\
245 \\
246 \\
291 \\
292 \\
293 \\
297 \\
298 \\
360 \\
366 \\
368 \\
369 \\
318 \\
328 \\
326\end{array}$ & $\begin{array}{r}10 \\
11 \\
14 \\
23 \\
24 \\
36 \\
42 \\
43 \\
47 \\
51 \\
52 \\
56 \\
62 \\
63 \\
65 \\
86 \\
92 \\
98 \\
161 \\
162 \\
166 \\
167 \\
114 \\
128 \\
121 \\
124 \\
125 \\
187 \\
189 \\
191 \\
192 \\
225 \\
226 \\
231 \\
232 \\
233 \\
241 \\
242 \\
244 \\
245 \\
246 \\
291 \\
292 \\
293 \\
297 \\
298 \\
360 \\
366 \\
368 \\
369 \\
316 \\
320 \\
326\end{array}$ & 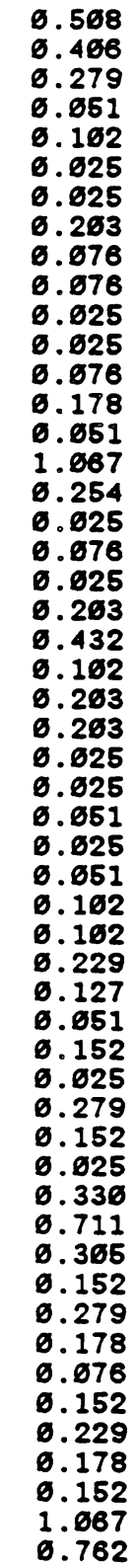 & $\begin{array}{r}6.568 \\
8.914 \\
1.194 \\
1.245 \\
1.346 \\
1.372 \\
1.397 \\
1.666 \\
1.676 \\
1.753 \\
1.778 \\
1.863 \\
1.886 \\
2.657 \\
2.168 \\
3.175 \\
3.429 \\
3.454 \\
3.531 \\
3.556 \\
3.759 \\
4.191 \\
4.293 \\
4.496 \\
4.699 \\
4.724 \\
4.756 \\
4.861 \\
4.826 \\
4.877 \\
4.978 \\
5.686 \\
5.369 \\
5.436 \\
5.486 \\
5.639 \\
5.664 \\
5.944 \\
6.896 \\
6.121 \\
6.452 \\
7.163 \\
7.468 \\
8.712 \\
7.665 \\
16.631 \\
7.899 \\
8.677 \\
8.153 \\
8.366 \\
\end{array}$ & $\begin{array}{r}6.588 \\
9.914 \\
1.194 \\
1.245 \\
1.346 \\
1.372 \\
1.397 \\
1.666 \\
1.676 \\
1.753 \\
1.778 \\
1.863 \\
1.886 \\
2.657 \\
2.168 \\
3.175 \\
3.429 \\
3.454 \\
3.531 \\
3.556 \\
3.759 \\
4.191 \\
4.293 \\
4.496 \\
4.699 \\
4.724 \\
4.756 \\
4.861 \\
4.826 \\
4.877 \\
4.978 \\
5.686 \\
5.369 \\
5.436 \\
5.486 \\
5.639 \\
5.664 \\
5.944 \\
6.896 \\
6.121 \\
6.452 \\
7.163 \\
7.468 \\
7.628 \\
7.899 \\
8.877 \\
8.153 \\
8.366 \\
8.534 \\
8.712 \\
8.865 \\
9.931 \\
16.693\end{array}$ \\
\hline
\end{tabular}




\section{TABLE A.2. (cont'd)}

PRECIPITATION DATA FROM THE HANFORD METEOROLOGICAL STATION 1979 TO JUNE 1987

\begin{tabular}{|c|c|c|c|c|c|}
\hline DATE & $\begin{array}{l}\text { DAYS SINCE } \\
\text { OI-JAN-79 }\end{array}$ & $\begin{array}{l}\text { DAY OF } \\
\text { YEAR }\end{array}$ & $\begin{array}{l}\text { PRECIP } \\
(C M)\end{array}$ & $\begin{array}{l}\text { CUMULATIVE } \\
\text { ANNUAL CM }\end{array}$ & $\begin{array}{l}\text { CUMULATIVE } \\
\text { TOTAL CM }\end{array}$ \\
\hline 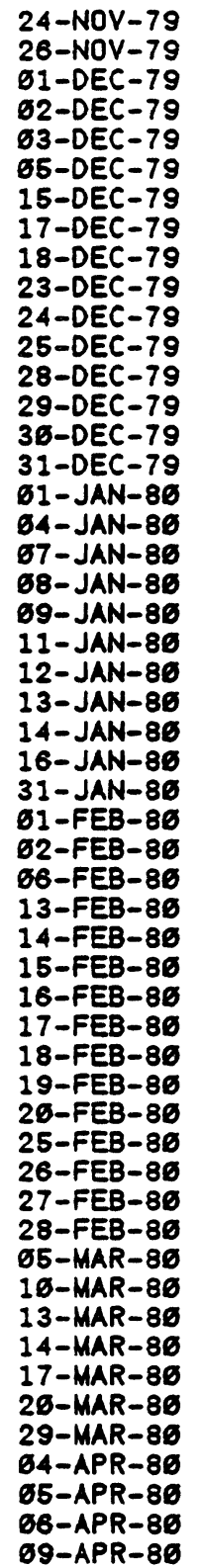 & $\begin{array}{l}328 \\
336 \\
335 \\
336 \\
337 \\
339 \\
349 \\
351 \\
352 \\
357 \\
358 \\
359 \\
362 \\
363 \\
364 \\
365 \\
366 \\
369 \\
372 \\
373 \\
374 \\
376 \\
377 \\
378 \\
379 \\
381 \\
396 \\
397 \\
398 \\
462 \\
469 \\
416 \\
411 \\
412 \\
413 \\
414 \\
415 \\
416 \\
421 \\
422 \\
423 \\
424 \\
436 \\
435 \\
438 \\
439 \\
442 \\
445 \\
454 \\
466 \\
461 \\
462 \\
465\end{array}$ & $\begin{array}{r}328 \\
336 \\
335 \\
336 \\
337 \\
339 \\
349 \\
351 \\
352 \\
357 \\
358 \\
359 \\
362 \\
363 \\
364 \\
365 \\
1 \\
4 \\
7 \\
8 \\
9 \\
11 \\
12 \\
13 \\
14 \\
16 \\
31 \\
32 \\
33 \\
37 \\
44 \\
45 \\
46 \\
47 \\
48 \\
49 \\
56 \\
51 \\
56 \\
57 \\
58 \\
59 \\
65 \\
76 \\
73 \\
74 \\
77 \\
86 \\
89 \\
95 \\
96 \\
97 \\
160\end{array}$ & 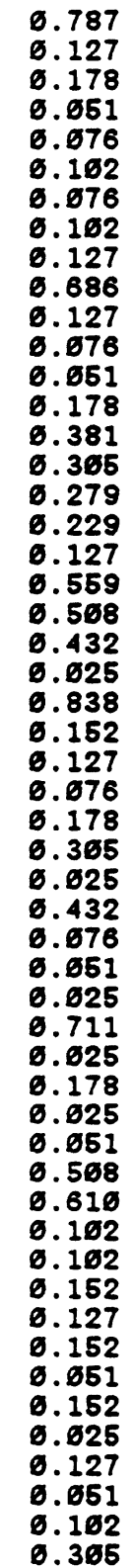 & $\begin{array}{l}11.481 \\
11.668 \\
11.786 \\
11.836 \\
11.913 \\
12.614 \\
12.896 \\
12.192 \\
12.319 \\
13.665 \\
13.132 \\
13.268 \\
13.259 \\
13.437 \\
13.818 \\
14.122 \\
6.279 \\
9.568 \\
6.635 \\
1.193 \\
1.761 \\
2.133 \\
2.159 \\
2.997 \\
3.149 \\
3.276 \\
3.352 \\
3.536 \\
3.835 \\
3.869 \\
4.292 \\
4.368 \\
4.419 \\
4.445 \\
5.156 \\
5.181 \\
5.359 \\
5.384 \\
5.435 \\
5.943 \\
6.553 \\
6.654 \\
6.756 \\
6.968 \\
7.835 \\
7.188 \\
7.239 \\
7.391 \\
7.416 \\
7.543 \\
7.594 \\
7.696 \\
8.861\end{array}$ & $\begin{array}{l}11.481 \\
11.668 \\
11.786 \\
11.836 \\
11.913 \\
12.614 \\
12.696 \\
12.192 \\
12.319 \\
13.665 \\
13.132 \\
13.268 \\
13.259 \\
13.437 \\
13.818 \\
14.122 \\
14.461 \\
14.636 \\
14.757 \\
15.316 \\
15.824 \\
16.256 \\
16.281 \\
17.119 \\
17.272 \\
17.399 \\
17.475 \\
17.653 \\
17.957 \\
17.983 \\
18.415 \\
18.491 \\
18.542 \\
18.567 \\
19.278 \\
19.364 \\
19.481 \\
19.567 \\
19.558 \\
29.666 \\
26.675 \\
26.777 \\
28.878 \\
21.831 \\
21.158 \\
21.316 \\
21.361 \\
21.513 \\
21.539 \\
21.666 \\
21.717 \\
21.818 \\
22.123\end{array}$ \\
\hline
\end{tabular}


TABLE A.2. (cont'd)

PRECIPITATION DATA FROM THE HAINFORD METEOROLOGICAL STATION 1979 TO JUNE 1987

\begin{tabular}{|c|c|c|c|c|c|}
\hline DATE & $\begin{array}{l}\text { DAYS SINCE } \\
\text { BI-JAN-79 }\end{array}$ & $\begin{array}{l}\text { DAY OF } \\
\text { YEAR }\end{array}$ & $\begin{array}{l}\text { PRECIP } \\
(\mathrm{CM})\end{array}$ & $\begin{array}{l}\text { CUMULATIVE } \\
\text { ANNUAL CM }\end{array}$ & $\begin{array}{l}\text { CUMULATIVE } \\
\text { TOTAL CM }\end{array}$ \\
\hline 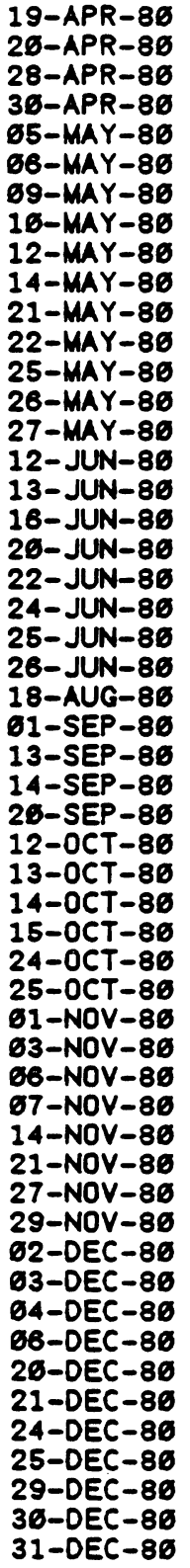 & $\begin{array}{l}475 \\
476 \\
484 \\
486 \\
491 \\
492 \\
495 \\
496 \\
498 \\
566 \\
567 \\
568 \\
511 \\
512 \\
513 \\
529 \\
536 \\
533 \\
537 \\
539 \\
541 \\
542 \\
543 \\
596 \\
616 \\
622 \\
623 \\
629 \\
651 \\
652 \\
653 \\
654 \\
663 \\
664 \\
671 \\
673 \\
676 \\
677 \\
684 \\
691 \\
697 \\
699 \\
762 \\
763 \\
784 \\
766 \\
726 \\
721 \\
724 \\
725 \\
729 \\
736 \\
731\end{array}$ & $\begin{array}{l}119 \\
111 \\
119 \\
121 \\
126 \\
127 \\
136 \\
131 \\
133 \\
135 \\
142 \\
143 \\
146 \\
147 \\
148 \\
164 \\
165 \\
168 \\
172 \\
174 \\
176 \\
177 \\
178 \\
231 \\
245 \\
257 \\
258 \\
264 \\
286 \\
287 \\
288 \\
289 \\
298 \\
299 \\
366 \\
368 \\
311 \\
312 \\
319 \\
326 \\
332 \\
334 \\
337 \\
338 \\
339 \\
341 \\
355 \\
356 \\
359 \\
366 \\
364 \\
365 \\
366\end{array}$ & 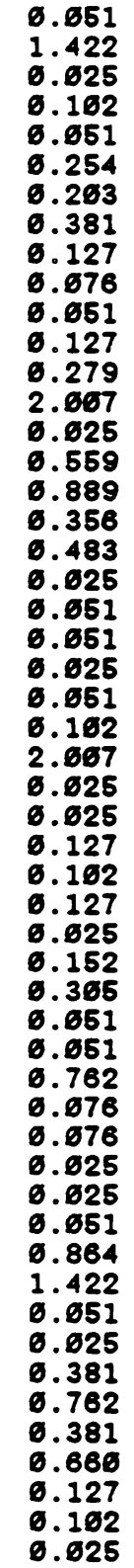 & $\begin{array}{r}8.651 \\
9.474 \\
9.499 \\
9.661 \\
9.652 \\
9.966 \\
16.169 \\
16.496 \\
16.617 \\
16.693 \\
16.744 \\
16.871 \\
11.156 \\
13.157 \\
13.182 \\
13.741 \\
14.636 \\
14.986 \\
15.468 \\
15.494 \\
15.544 \\
15.595 \\
15.621 \\
15.671 \\
15.773 \\
17.786 \\
17.865 \\
17.836 \\
17.957 \\
18.659 \\
18.186 \\
18.211 \\
18.364 \\
18.669 \\
18.719 \\
18.776 \\
19.532 \\
19.868 \\
19.685 \\
19.716 \\
19.735 \\
19.786 \\
28.656 \\
22.672 \\
22.123 \\
22.148 \\
22.529 \\
23.291 \\
23.672 \\
24.333 \\
24.466 \\
24.561 \\
24.587\end{array}$ & $\begin{array}{l}22.174 \\
23.596 \\
23.622 \\
23.723 \\
23.774 \\
24.828 \\
24.231 \\
24.612 \\
24.739 \\
24.815 \\
24.866 \\
24.993 \\
25.273 \\
27.279 \\
27.365 \\
27.863 \\
28.752 \\
29.168 \\
29.591 \\
29.616 \\
29.667 \\
29.718 \\
29.743 \\
29.794 \\
29.895 \\
31.962 \\
31.927 \\
31.953 \\
32.886 \\
32.181 \\
32.368 \\
32.334 \\
32.486 \\
32.791 \\
32.842 \\
32.893 \\
33.655 \\
33.731 \\
33.867 \\
33.832 \\
33.858 \\
33.969 \\
34.772 \\
36.195 \\
36.245 \\
36.271 \\
36.652 \\
37.414 \\
37.795 \\
38.455 \\
38.582 \\
38.684 \\
38.769\end{array}$ \\
\hline
\end{tabular}


TABLE A.2. (cont'd)

PRECIPITKTION DATA FROM THE HAINFORD METEOROLOGICAL STATION

1979 TO JUNE 1987

\begin{tabular}{|c|c|c|c|c|c|}
\hline DATE & $\begin{array}{l}\text { DAYS SINCE } \\
\text { BI-JAN-79 }\end{array}$ & $\begin{array}{l}\text { DAY OF } \\
\text { YEAR }\end{array}$ & $\begin{array}{l}\text { PRECIP } \\
(\mathrm{CM})\end{array}$ & $\begin{array}{l}\text { CUMULATIVE } \\
\text { ANNUAL CM }\end{array}$ & $\begin{array}{l}\text { CUMULATIVE } \\
\text { TOTAL CM }\end{array}$ \\
\hline $\begin{array}{l}\text { פ1-JAN-81 } \\
17-J A N-81 \\
19-J A N-81 \\
21-J A N-81 \\
22-J A N-81 \\
26-J A N-81 \\
27-J A N-81 \\
28-J A N-81 \\
29-J A N-81 \\
13-F E B-81 \\
15-F E B-81 \\
18-F E B-81 \\
19-F E B-81 \\
24-F E B-81 \\
26-F E B-81 \\
64-M A R-81 \\
16-M A R-81 \\
25-M A R-81 \\
26-M A R-81 \\
22-A P R-81 \\
14-M A Y-81 \\
17-M A Y-81 \\
18-M A Y-81 \\
19-M A Y-81 \\
25-M A Y-81 \\
62-J U N-81 \\
65-J U N-81 \\
67-J U N-81 \\
68-J U N-81 \\
65-J U L-81 \\
19-A U G-81 \\
26-A U G-81 \\
26-S E P-81 \\
27-S E P-81 \\
66-O C T-81 \\
27-O C T-81 \\
28-O C T-81 \\
29-O C T-81 \\
11-N O V-81 \\
13-N O V-81 \\
14-N O V-81 \\
15-N O V-81 \\
16-N O V-81 \\
17-N O V-81 \\
21-N O V-81 \\
65-D E C-81 \\
66-D E C-81 \\
69-D E C-81 \\
13-D E C-81 \\
14-D E C-81 \\
15-D E C-81 \\
18-D E C-81 \\
19-D E C-81\end{array}$ & $\begin{array}{l}732 \\
748 \\
756 \\
752 \\
753 \\
757 \\
758 \\
759 \\
766 \\
775 \\
777 \\
786 \\
781 \\
786 \\
788 \\
794 \\
866 \\
815 \\
816 \\
843 \\
865 \\
868 \\
869 \\
876 \\
876 \\
884 \\
887 \\
889 \\
896 \\
917 \\
962 \\
963 \\
1666 \\
1661 \\
1616 \\
1631 \\
1632 \\
1633 \\
1646 \\
1648 \\
1649 \\
1656 \\
1651 \\
1652 \\
1656 \\
167 \varnothing \\
1671 \\
1674 \\
1678 \\
1679 \\
1686 \\
1683 \\
1684\end{array}$ & $\begin{array}{r}1 \\
17 \\
19 \\
21 \\
22 \\
26 \\
27 \\
28 \\
29 \\
44 \\
46 \\
49 \\
56 \\
55 \\
57 \\
63 \\
75 \\
84 \\
85 \\
112 \\
134 \\
137 \\
138 \\
139 \\
145 \\
153 \\
156 \\
158 \\
159 \\
186 \\
231 \\
232 \\
269 \\
276 \\
279 \\
366 \\
361 \\
362 \\
315 \\
317 \\
318 \\
319 \\
320 \\
321 \\
325 \\
339 \\
346 \\
343 \\
347 \\
348 \\
349 \\
352 \\
353\end{array}$ & 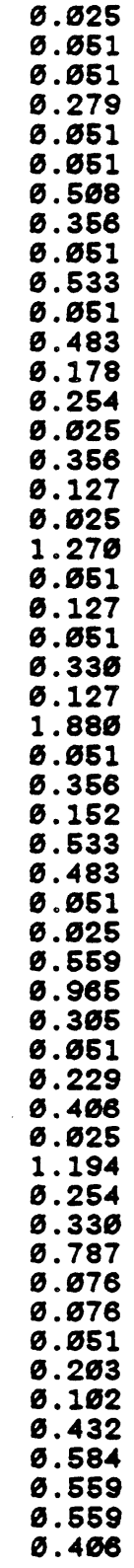 & $\begin{array}{r}9.825 \\
6.876 \\
9.127 \\
9.466 \\
6.457 \\
6.568 \\
1.616 \\
1.372 \\
1.422 \\
1.956 \\
2.667 \\
2.489 \\
2.667 \\
2.921 \\
2.946 \\
3.362 \\
3.429 \\
3.454 \\
4.724 \\
4.775 \\
4.962 \\
4.953 \\
5.283 \\
5.416 \\
7.296 \\
7.341 \\
7.696 \\
7.849 \\
8.382 \\
8.865 \\
8.915 \\
8.941 \\
9.566 \\
16.465 \\
16.776 \\
16.826 \\
11.649 \\
11.455 \\
11.481 \\
12.675 \\
12.929 \\
13.259 \\
14.846 \\
14.122 \\
14.199 \\
14.249 \\
14.453 \\
14.554 \\
14.986 \\
15.576 \\
16.129 \\
16.688 \\
17.694\end{array}$ & $\begin{array}{l}38.735 \\
38.785 \\
38.836 \\
39.116 \\
39.166 \\
39.217 \\
39.725 \\
46.881 \\
46.132 \\
46.665 \\
46.716 \\
41.198 \\
41.376 \\
41.636 \\
41.656 \\
42.611 \\
42.138 \\
42.164 \\
43.434 \\
43.484 \\
43.611 \\
43.662 \\
43.992 \\
44.119 \\
45.999 \\
46.658 \\
46.465 \\
46.558 \\
47.891 \\
47.574 \\
47.625 \\
47.658 \\
48.289 \\
49.174 \\
49.479 \\
49.536 \\
49.758 \\
56.165 \\
58.196 \\
51.384 \\
51.638 \\
51.968 \\
52.755 \\
52.832 \\
52.968 \\
52.959 \\
53.162 \\
53.263 \\
53.695 \\
54.279 \\
54.838 \\
55.397 \\
55.863\end{array}$ \\
\hline
\end{tabular}




\section{TABLE A.2. (cont'd)}

PRECIPITATION DATA FROM THE HANFORD METEOROLOGICAL STATION 1979 TO JUNE 1987

\begin{tabular}{|c|c|c|c|c|c|}
\hline DATE & $\begin{array}{l}\text { DAYS SINCE } \\
\text { פI-JAN-79 }\end{array}$ & $\begin{array}{l}\text { DAY OF } \\
\text { YEAR }\end{array}$ & $\begin{array}{l}\text { PRECIP } \\
\text { (CM) }\end{array}$ & $\begin{array}{l}\text { CUMULATIVE } \\
\text { ANNUAL CM }\end{array}$ & $\begin{array}{l}\text { CUMULATIVE } \\
\text { TOTAL CM }\end{array}$ \\
\hline 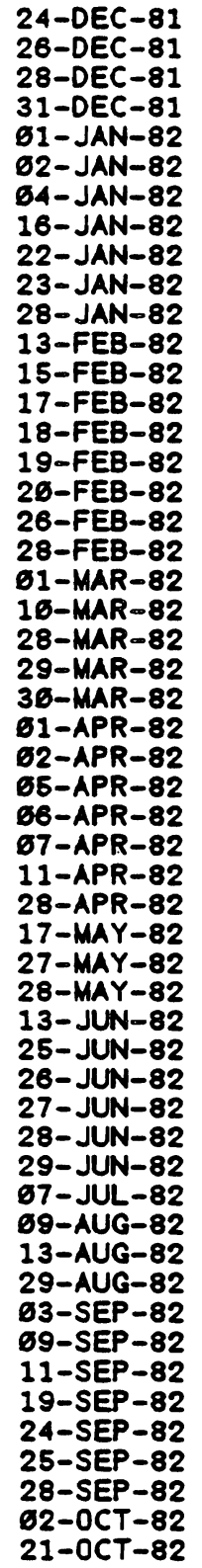 & $\begin{array}{l}1689 \\
1691 \\
1693 \\
1696 \\
1697 \\
1698 \\
1166 \\
1112 \\
1118 \\
1119 \\
1124 \\
1146 \\
1142 \\
1144 \\
1145 \\
1146 \\
1147 \\
1153 \\
1155 \\
1156 \\
1165 \\
1183 \\
1184 \\
1185 \\
1187 \\
1188 \\
1191 \\
1192 \\
1193 \\
1197 \\
1214 \\
1233 \\
1243 \\
1244 \\
1266 \\
1272 \\
1273 \\
1274 \\
1275 \\
1276 \\
1284 \\
1317 \\
1321 \\
1337 \\
1342 \\
1348 \\
1356 \\
1358 \\
1363 \\
1364 \\
1367 \\
1371 \\
1396\end{array}$ & $\begin{array}{r}358 \\
366 \\
362 \\
365 \\
1 \\
2 \\
4 \\
16 \\
22 \\
23 \\
28 \\
44 \\
46 \\
48 \\
49 \\
58 \\
51 \\
57 \\
59 \\
68 \\
69 \\
87 \\
88 \\
89 \\
91 \\
92 \\
95 \\
98 \\
97 \\
161 \\
118 \\
137 \\
147 \\
148 \\
164 \\
176 \\
177 \\
178 \\
179 \\
186 \\
188 \\
221 \\
225 \\
241 \\
246 \\
252 \\
254 \\
262 \\
267 \\
268 \\
271 \\
275 \\
294\end{array}$ & $\begin{array}{l}6.356 \\
6.263 \\
6.162 \\
6.127 \\
6.127 \\
6.127 \\
6.162 \\
6.127 \\
6.263 \\
6.625 \\
6.127 \\
6.263 \\
6.568 \\
6.625 \\
6.162 \\
6.229 \\
6.127 \\
6.625 \\
6.229 \\
6.229 \\
6.651 \\
6.676 \\
6.625 \\
6.651 \\
6.625 \\
6.152 \\
6.676 \\
6.914 \\
6.651 \\
6.584 \\
6.162 \\
6.336 \\
6.127 \\
6.254 \\
6.127 \\
6.625 \\
6.686 \\
6.787 \\
6.229 \\
6.651 \\
6.559 \\
6.254 \\
6.162 \\
6.152 \\
6.651 \\
6.676 \\
6.127 \\
6.432 \\
6.625 \\
6.635 \\
6.651 \\
6.676 \\
6.466\end{array}$ & $\begin{array}{r}17.456 \\
17.653 \\
17.755 \\
17.882 \\
6.127 \\
6.254 \\
6.356 \\
6.483 \\
6.686 \\
9.711 \\
6.838 \\
1.641 \\
1.549 \\
1.575 \\
1.676 \\
1.965 \\
2.832 \\
2.657 \\
2.286 \\
2.515 \\
2.585 \\
2.642 \\
2.667 \\
2.718 \\
2.743 \\
2.896 \\
2.972 \\
3.886 \\
3.937 \\
4.521 \\
4.623 \\
4.953 \\
5.686 \\
5.334 \\
5.461 \\
5.486 \\
6.172 \\
6.966 \\
7.188 \\
7.239 \\
7.798 \\
8.652 \\
8.153 \\
8.366 \\
8.357 \\
8.433 \\
8.560 \\
8.992 \\
9.617 \\
9.652 \\
9.763 \\
9.779 \\
16.185\end{array}$ & $\begin{array}{l}56.159 \\
56.362 \\
56.464 \\
56.591 \\
56.718 \\
56.845 \\
56.946 \\
57.673 \\
57.277 \\
57.362 \\
57.429 \\
57.632 \\
58.146 \\
58.166 \\
58.267 \\
58.496 \\
58.623 \\
58.648 \\
58.877 \\
59.165 \\
59.156 \\
59.232 \\
59.258 \\
59.369 \\
59.334 \\
59.486 \\
59.563 \\
66.477 \\
66.528 \\
61.112 \\
61.214 \\
61.544 \\
61.671 \\
61.925 \\
62.652 \\
62.677 \\
62.763 \\
63.556 \\
63.779 \\
63.836 \\
64.389 \\
64.643 \\
64.744 \\
64.897 \\
64.947 \\
65.624 \\
65.151 \\
65.582 \\
65.668 \\
66.243 \\
66.294 \\
66.376 \\
66.776\end{array}$ \\
\hline
\end{tabular}


TABLE A.2. (cont'd)

PRECIPITATION DATA FROM THE HANFORD METEOROLOGICAL STATION 1979 TO JUNE 1987

\begin{tabular}{|c|c|c|c|c|c|}
\hline ATE & $\begin{array}{l}\text { DAYS SINCE } \\
\text { B1-JAN-79 }\end{array}$ & $\begin{array}{l}\text { DAY OF } \\
\text { YEAR }\end{array}$ & $\begin{array}{l}\text { PRECIP } \\
(C M)\end{array}$ & $\begin{array}{l}\text { CUMULATIVE } \\
\text { ANNUAL CM }\end{array}$ & $\begin{array}{l}\text { CUMULATIVE } \\
\text { TOTAL CM }\end{array}$ \\
\hline 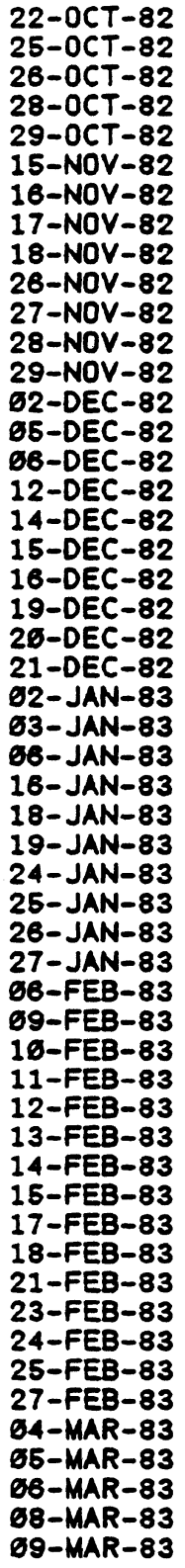 & $\begin{array}{l}1391 \\
1394 \\
1395 \\
1397 \\
1398 \\
1415 \\
1416 \\
1417 \\
1418 \\
1426 \\
1427 \\
1428 \\
1429 \\
1432 \\
1435 \\
1436 \\
1442 \\
1444 \\
1445 \\
1446 \\
1449 \\
1450 \\
1451 \\
1463 \\
1464 \\
1467 \\
1477 \\
1479 \\
1486 \\
1485 \\
1486 \\
1487 \\
1488 \\
1498 \\
1561 \\
1562 \\
1563 \\
1564 \\
1565 \\
1566 \\
1567 \\
1569 \\
1510 \\
1513 \\
1515 \\
1516 \\
1517 \\
1519 \\
1524 \\
1525 \\
1526 \\
1528 \\
1529\end{array}$ & $\begin{array}{r}295 \\
298 \\
299 \\
381 \\
362 \\
319 \\
326 \\
321 \\
322 \\
336 \\
331 \\
332 \\
333 \\
336 \\
339 \\
346 \\
346 \\
348 \\
349 \\
356 \\
353 \\
354 \\
356 \\
2 \\
3 \\
6 \\
16 \\
18 \\
19 \\
24 \\
25 \\
26 \\
27 \\
37 \\
46 \\
41 \\
42 \\
43 \\
44 \\
46 \\
46 \\
48 \\
49 \\
52 \\
54 \\
55 \\
56 \\
58 \\
63 \\
64 \\
65 \\
67 \\
68\end{array}$ & 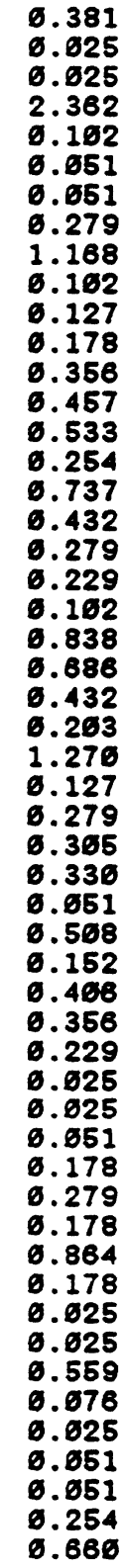 & $\begin{array}{r}16.566 \\
16.592 \\
16.617 \\
12.979 \\
13.681 \\
13.132 \\
13.183 \\
13.462 \\
14.636 \\
14.732 \\
14.859 \\
15.637 \\
15.392 \\
15.856 \\
16.383 \\
16.637 \\
17.374 \\
17.865 \\
18.685 \\
18.313 \\
18.415 \\
19.253 \\
19.939 \\
6.431 \\
6.634 \\
1.964 \\
2.631 \\
2.311 \\
2.615 \\
2.946 \\
2.996 \\
3.564 \\
3.657 \\
4.663 \\
4.419 \\
4.647 \\
4.673 \\
4.698 \\
4.749 \\
4.927 \\
5.266 \\
5.384 \\
6.248 \\
6.425 \\
6.451 \\
6.476 \\
7.635 \\
7.111 \\
7.136 \\
7.187 \\
7.238 \\
7.492 \\
8.152\end{array}$ & $\begin{array}{l}67.157 \\
67.183 \\
67.268 \\
69.576 \\
69.672 \\
69.723 \\
69.773 \\
78.653 \\
71.221 \\
71.323 \\
71.456 \\
71.628 \\
71.983 \\
72.446 \\
72.974 \\
73.228 \\
73.964 \\
74.396 \\
74.676 \\
74.964 \\
75.866 \\
75.844 \\
76.536 \\
76.962 \\
77.165 \\
78.435 \\
78.562 \\
78.841 \\
79.146 \\
79.476 \\
79.527 \\
86.935 \\
86.187 \\
86.594 \\
86.949 \\
81.178 \\
81.263 \\
81.229 \\
81.286 \\
81.457 \\
81.737 \\
81.915 \\
82.778 \\
82.956 \\
82.981 \\
83.867 \\
83.566 \\
83.642 \\
83.667 \\
83.718 \\
83.769 \\
84.823 \\
84.683\end{array}$ \\
\hline
\end{tabular}


TABLE A.2. (cont'd)

PRECIPITATION DRTA FROM THE HANFORD METEOROLOGICAL STATION 1979 TO JUNE 1987

\begin{tabular}{|c|c|c|c|c|c|}
\hline DATE & $\begin{array}{l}\text { DAYS SINCE } \\
\text { OI-JAN-79 }\end{array}$ & $\begin{array}{l}\text { DAY OF } \\
\text { YEAR }\end{array}$ & $\begin{array}{l}\text { PRECIP } \\
\text { (CM) }\end{array}$ & $\begin{array}{l}\text { CUMULATIVE } \\
\text { ANNUAL CM }\end{array}$ & $\begin{array}{l}\text { CUMULATIVE } \\
\text { TOTAL CM }\end{array}$ \\
\hline $\begin{array}{l}16-\text { MAR }-83 \\
12-M A R-83 \\
13-M A R-83 \\
27-M A R-83 \\
29-M A R-83 \\
61-A P R-83 \\
62-A P R-83 \\
23-A P R-83 \\
36-A P R-83 \\
65-M A Y-83 \\
67-M A Y-83 \\
68-M A Y-83 \\
16-J U N-83 \\
14-J U N-83 \\
18-J U N-83 \\
19-J U N-83 \\
22-J U N-83 \\
23-J U N-83 \\
27-J U N-83 \\
29-J U N-83 \\
61-J U L-83 \\
23-J U L-83 \\
24-J U L-83 \\
25-J U L-83 \\
27-J U L-83 \\
11-A U G-83 \\
26-A U G-83 \\
27-A U G-83 \\
28-A U G-83 \\
29-A U G-83 \\
61-S E P-83 \\
18-S E P-83 \\
17-O C T-83 \\
22-O C T-83 \\
36-O C T-83 \\
31-O C T-83 \\
61-N O V-83 \\
62-N O V-83 \\
63-N O V-83 \\
65-N O V-83 \\
66-N O V-83 \\
69-N O V-83 \\
16-N O V-83 \\
12-N O V-83 \\
13-N O V-83 \\
14-N O V-83 \\
15-N O V-83 \\
16-N O V-83 \\
17-N O V-83 \\
19-N O V-83 \\
21-N O V-83 \\
23-N O V-83 \\
24-N O V-83\end{array}$ & $\begin{array}{l}1536 \\
1532 \\
1533 \\
1547 \\
1549 \\
1552 \\
1553 \\
1574 \\
1581 \\
1586 \\
1588 \\
1589 \\
1622 \\
1626 \\
1636 \\
1631 \\
1634 \\
1635 \\
1639 \\
1641 \\
1643 \\
1665 \\
1666 \\
1667 \\
1669 \\
1684 \\
1699 \\
1766 \\
1761 \\
1782 \\
1765 \\
1722 \\
1751 \\
1756 \\
1764 \\
1765 \\
1766 \\
1767 \\
1788 \\
1776 \\
1771 \\
1774 \\
1775 \\
1777 \\
1778 \\
1779 \\
1786 \\
1781 \\
1782 \\
1784 \\
1786 \\
1788 \\
1789\end{array}$ & $\begin{array}{r}69 \\
71 \\
72 \\
86 \\
88 \\
91 \\
92 \\
113 \\
128 \\
125 \\
127 \\
128 \\
161 \\
165 \\
169 \\
176 \\
173 \\
174 \\
178 \\
186 \\
182 \\
264 \\
265 \\
268 \\
268 \\
223 \\
238 \\
239 \\
246 \\
241 \\
244 \\
261 \\
296 \\
295 \\
363 \\
364 \\
365 \\
368 \\
367 \\
369 \\
316 \\
313 \\
314 \\
316 \\
317 \\
318 \\
319 \\
328 \\
321 \\
323 \\
325 \\
327 \\
328\end{array}$ & 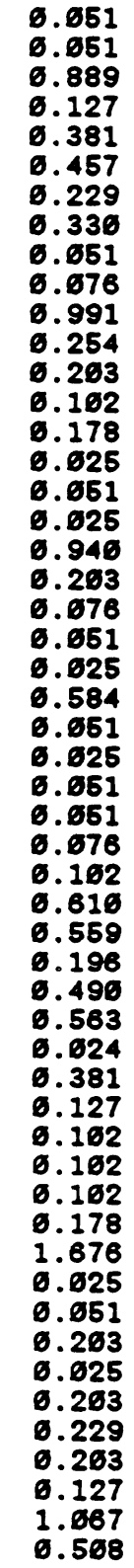 & $\begin{array}{r}8.263 \\
8.254 \\
9.143 \\
9.276 \\
9.651 \\
16.168 \\
16.337 \\
16.867 \\
16.718 \\
16.794 \\
11.785 \\
12.839 \\
12.242 \\
12.344 \\
12.522 \\
12.547 \\
12.598 \\
12.623 \\
13.563 \\
13.766 \\
13.842 \\
13.893 \\
13.918 \\
14.562 \\
14.553 \\
14.578 \\
14.629 \\
14.686 \\
14.756 \\
14.858 \\
15.468 \\
16.627 \\
16.223 \\
16.713 \\
17.276 \\
17.366 \\
17.681 \\
17.868 \\
17.916 \\
18.611 \\
18.113 \\
18.291 \\
19.967 \\
19.993 \\
29.643 \\
26.247 \\
26.272 \\
26.475 \\
26.764 \\
26.967 \\
21.634 \\
22.161 \\
22.869\end{array}$ & $\begin{array}{l}84.734 \\
84.785 \\
85.674 \\
85.861 \\
86.182 \\
86.639 \\
86.868 \\
87.198 \\
87.249 \\
87.325 \\
88.316 \\
88.576 \\
88.773 \\
88.875 \\
89.853 \\
89.678 \\
89.129 \\
89.154 \\
96.894 \\
96.297 \\
96.373 \\
96.424 \\
96.449 \\
91.633 \\
91.684 \\
91.169 \\
91.166 \\
91.211 \\
91.287 \\
91.389 \\
91.999 \\
92.558 \\
92.754 \\
93.244 \\
93.867 \\
93.831 \\
94.212 \\
94.339 \\
94.446 \\
94.542 \\
94.644 \\
94.821 \\
96.498 \\
96.523 \\
96.574 \\
96.777 \\
96.863 \\
97.668 \\
97.234 \\
97.438 \\
97.565 \\
98.631 \\
99.139\end{array}$ \\
\hline
\end{tabular}


TABLE A.2. (cont'd)

PRECIFITATION DATA FROM THE HAINFORD METEOROLOGICAL STATION 1979 TO JUNE 1987

\begin{tabular}{|c|c|c|c|c|c|}
\hline DATE & $\begin{array}{l}\text { DAYS SINCE } \\
\text { EI-JAN-79 }\end{array}$ & $\begin{array}{l}\text { DAY OF } \\
\text { YEAR }\end{array}$ & $\begin{array}{l}\text { PRECIP } \\
(\mathrm{CM})\end{array}$ & $\begin{array}{l}\text { CUMULATIVE } \\
\text { ANNUAL CM }\end{array}$ & $\begin{array}{l}\text { CUMULATIVE } \\
\text { TOTAL CM }\end{array}$ \\
\hline $\begin{array}{l}28-N O V-83 \\
\text { 62-DEC-83 } \\
\text { g4-DEC-83 } \\
65-D E C-83 \\
67-D E C-83 \\
69-D E C-83 \\
16-D E C-83 \\
12-D E C-83 \\
14-D E C-83 \\
16-D E C-83 \\
18-D E C-83 \\
19-D E C-83 \\
24-D E C-83 \\
25-D E C-83 \\
27-D E C-83 \\
29-D E C-83 \\
62-J A N-84 \\
63-J A N-84 \\
16-J A N-84 \\
21-J A N-84 \\
\text { 65-FEB-84 } \\
68-F E B-84 \\
69-F E B-84 \\
11-F E B-84 \\
12-F E B-84 \\
13-F E B-84 \\
15-F E B-84 \\
19-F E B-84 \\
26-F E B-84 \\
21-F E B-84 \\
23-F E B-84 \\
24-F E B-84 \\
25-F E B-84 \\
29-F E B-84 \\
61-M A R-84 \\
16-M A R-84 \\
13-M A R-84 \\
15-M A R-84 \\
16-M A R-84 \\
18-M A R-84 \\
19-M A R-84 \\
26-M A R-84 \\
21-M A R-84 \\
25-M A R-84 \\
26-M A R-84 \\
28-M A R-84 \\
\text { 64-APR-84 } \\
67-A P R-84 \\
12-A P R-84 \\
18-A P R-84 \\
36-A P R-84 \\
61-M A Y-84 \\
11-M A Y-84\end{array}$ & $\begin{array}{l}1793 \\
1797 \\
1799 \\
1866 \\
1862 \\
1864 \\
1865 \\
1867 \\
1869 \\
1811 \\
1813 \\
1814 \\
1819 \\
1826 \\
1822 \\
1824 \\
1828 \\
1829 \\
1836 \\
1847 \\
1862 \\
1865 \\
1866 \\
1868 \\
1869 \\
1876 \\
1872 \\
1876 \\
1877 \\
1878 \\
1886 \\
1881 \\
1882 \\
1886 \\
1887 \\
1896 \\
1899 \\
1961 \\
1962 \\
1964 \\
1965 \\
1966 \\
1967 \\
1911 \\
1912 \\
1914 \\
1921 \\
1924 \\
1929 \\
1935 \\
1947 \\
1948 \\
1958\end{array}$ & $\begin{array}{r}332 \\
336 \\
338 \\
339 \\
341 \\
343 \\
344 \\
346 \\
348 \\
356 \\
352 \\
353 \\
358 \\
359 \\
361 \\
363 \\
2 \\
3 \\
10 \\
21 \\
36 \\
39 \\
46 \\
42 \\
43 \\
44 \\
46 \\
56 \\
51 \\
52 \\
54 \\
55 \\
56 \\
60 \\
61 \\
76 \\
73 \\
75 \\
76 \\
78 \\
79 \\
86 \\
81 \\
85 \\
86 \\
88 \\
95 \\
98 \\
163 \\
169 \\
121 \\
122 \\
132\end{array}$ & 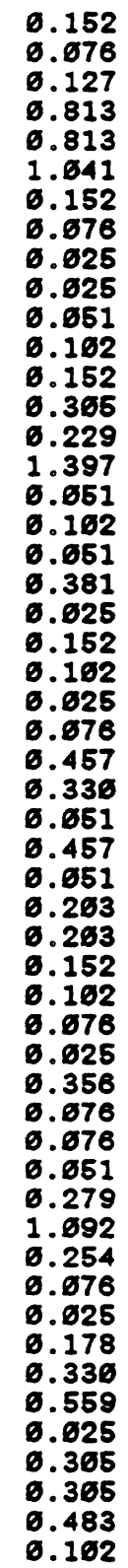 & $\begin{array}{l}22.761 \\
22.837 \\
22.964 \\
23.777 \\
24.596 \\
25.631 \\
25.784 \\
25.866 \\
25.885 \\
25.911 \\
25.962 \\
26.863 \\
26.216 \\
26.520 \\
26.749 \\
28.146 \\
6.651 \\
6.152 \\
6.263 \\
6.584 \\
6.616 \\
6.762 \\
6.864 \\
6.889 \\
6.965 \\
1.422 \\
1.753 \\
1.863 \\
2.261 \\
2.311 \\
2.515 \\
2.718 \\
2.876 \\
2.972 \\
3.648 \\
3.673 \\
3.429 \\
3.565 \\
3.581 \\
3.632 \\
3.912 \\
5.664 \\
5.258 \\
5.334 \\
5.359 \\
5.537 \\
5.867 \\
6.426 \\
6.452 \\
6.756 \\
7.661 \\
7.544 \\
7.645\end{array}$ & $\begin{array}{r}99.292 \\
99.368 \\
99.495 \\
166.368 \\
161.121 \\
162.162 \\
162.314 \\
162.391 \\
162.416 \\
162.441 \\
162.492 \\
162.594 \\
162.746 \\
163.651 \\
163.286 \\
164.677 \\
164.727 \\
164.829 \\
164.886 \\
165.261 \\
165.286 \\
165.439 \\
165.546 \\
165.566 \\
165.642 \\
166.899 \\
166.429 \\
166.486 \\
166.937 \\
166.988 \\
167.191 \\
167.394 \\
167.547 \\
167.648 \\
167.725 \\
167.756 \\
168.166 \\
168.182 \\
168.258 \\
168.389 \\
168.588 \\
169.686 \\
169.934 \\
116.911 \\
116.936 \\
116.214 \\
116.544 \\
111.163 \\
111.128 \\
111.433 \\
111.738 \\
112.226 \\
112.322\end{array}$ \\
\hline
\end{tabular}


TABLE A.2. (cont'd)

PRECIPITATION DATA FROM THE HANFORD METEOROLUGICAL STATION 1979 TO JUNE 1987

\begin{tabular}{|c|c|c|c|c|c|}
\hline DATE & $\begin{array}{l}\text { DAYS SINCE } \\
\text { BI-JAN-79 }\end{array}$ & $\begin{array}{l}\text { DAY OF } \\
\text { YEAR }\end{array}$ & $\begin{array}{l}\text { PRECIP } \\
(\mathrm{CM})\end{array}$ & $\begin{array}{l}\text { CUMULATIVE } \\
\text { ANNUAL CM }\end{array}$ & $\begin{array}{l}\text { CUMULATIVE } \\
\text { TOTAL CM }\end{array}$ \\
\hline 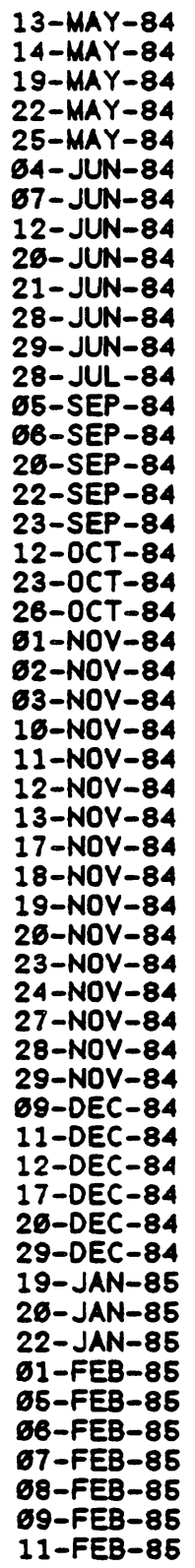 & $\begin{array}{l}1960 \\
1961 \\
1966 \\
1969 \\
1972 \\
1982 \\
1985 \\
1996 \\
1998 \\
1999 \\
2666 \\
2667 \\
2636 \\
2675 \\
2676 \\
2696 \\
2692 \\
2693 \\
2112 \\
2123 \\
2126 \\
2132 \\
2133 \\
2134 \\
2141 \\
2142 \\
2143 \\
2144 \\
2148 \\
2149 \\
2156 \\
2151 \\
2154 \\
2155 \\
2158 \\
2159 \\
2160 \\
2176 \\
2172 \\
2173 \\
2178 \\
2181 \\
2196 \\
2211 \\
2212 \\
2214 \\
2224 \\
2228 \\
2229 \\
2236 \\
2231 \\
2232 \\
2234\end{array}$ & $\begin{array}{l}134 \\
135 \\
146 \\
143 \\
146 \\
156 \\
159 \\
164 \\
172 \\
173 \\
186 \\
181 \\
216 \\
249 \\
256 \\
264 \\
266 \\
267 \\
286 \\
297 \\
366 \\
366 \\
367 \\
368 \\
315 \\
316 \\
317 \\
318 \\
322 \\
323 \\
324 \\
325 \\
328 \\
329 \\
332 \\
333 \\
334 \\
344 \\
346 \\
347 \\
352 \\
355 \\
364 \\
19 \\
26 \\
22 \\
32 \\
36 \\
37 \\
38 \\
39 \\
46 \\
42\end{array}$ & 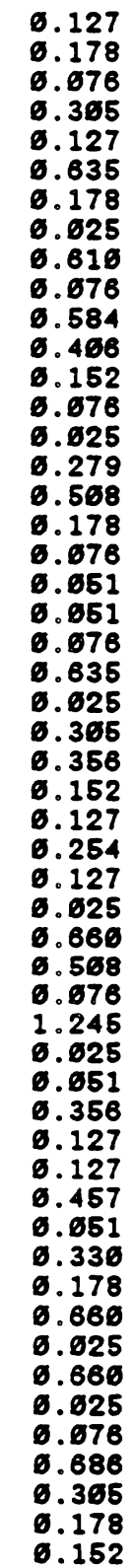 & $\begin{array}{r}7.772 \\
7.956 \\
8.626 \\
8.331 \\
8.458 \\
9.693 \\
9.271 \\
9.296 \\
9.966 \\
9.982 \\
16.566 \\
16.973 \\
11.125 \\
11.261 \\
11.227 \\
11.566 \\
12.614 \\
12.192 \\
12.268 \\
12.319 \\
12.376 \\
12.446 \\
13.681 \\
13.166 \\
13.411 \\
13.767 \\
13.919 \\
14.646 \\
14.366 \\
14.427 \\
14.453 \\
15.113 \\
15.621 \\
15.697 \\
16.942 \\
16.987 \\
17.618 \\
17.374 \\
17.561 \\
17.628 \\
18.685 \\
18.136 \\
18.466 \\
8.177 \\
9.837 \\
6.863 \\
1.523 \\
1.549 \\
1.625 \\
2.311 \\
2.615 \\
2.793 \\
2.946\end{array}$ & 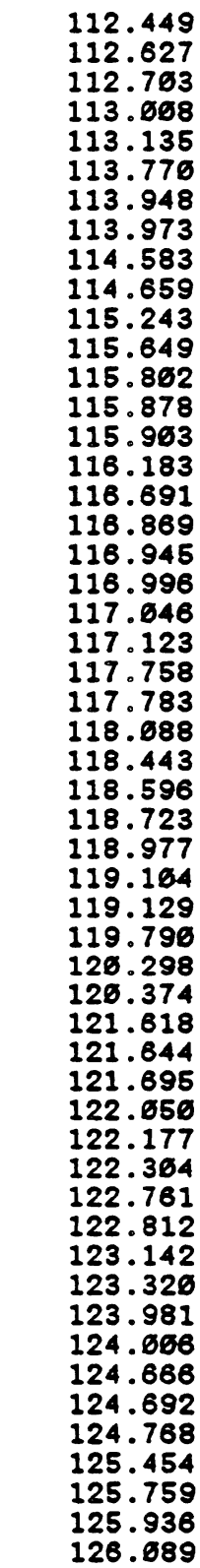 \\
\hline
\end{tabular}


TABLE A.2. (cont'd)

PRECIPITA.TIOIN DATA. FROM THE HAINFORD METEOROLOGICAL STATION
1979 TO JUNE 1987

DATE DAYS SINCE DAY OF PRECIP CUMULATIVE CUMULATIVE

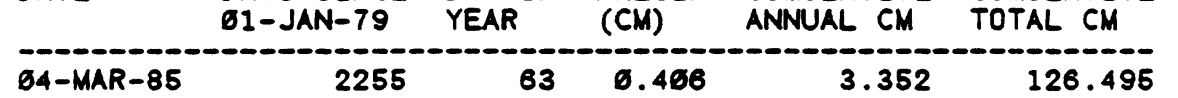

$\begin{array}{llllll}\text { GA-MAR-85 } & 2255 & 63 & 0.466 & 3.352 & 126.495 \\ 23-M A R-85 & 2274 & 82 & 6.263 & 3.555 & 126.698\end{array}$

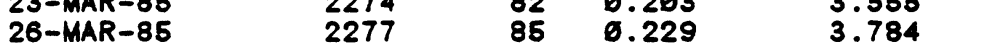

$\begin{array}{lllll}20-M A R-85 & 2279 & 85 & 126.927\end{array}$

$\begin{array}{llllll}29-M A R-85 & 2286 & 88 & 6.651 & 3.835 & 126.978 \\ 38-M A R-85 & 2281 & 89 & 6.025 & 3.860 & 127.063\end{array}$

$\begin{array}{llllll}22-A P R-85 & 2384 & 112 & 0.825 & 3.885 & 127.829\end{array}$

$\begin{array}{llllll}\text { O4-MAY-85 } & 2316 & 124 & 6.636 & 3.921 & 127.064 \\ 13-M A Y-85 & 2325 & 133 & 6.279 & 4.206 & 127.344\end{array}$

$\begin{array}{llllll}13-M A Y-85 & 2325 & 133 & 6.279 & 4.260 & 127.344\end{array}$

$\begin{array}{llllll}67-J U N-85 & 2349 & 157 & 6.356 & 4.556 & 127.699 \\ 31-J U L-85 & 235 \delta & 158 & 6.625 & 4.581 & 127.725\end{array}$

$\begin{array}{llllll}31-J U L-85 & 2464 & 212 & 6.365 & 4.886 & 128.629\end{array}$

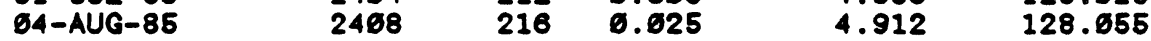

$\begin{array}{llllll}61-S E P-85 & 2436 & 244 & 6.651 & 4.962 & 128.166\end{array}$

$\begin{array}{llllll}\text { 68-SEP-85 } & 2443 & 251 & 6.254 & 5.216 & 128.360\end{array}$

$\begin{array}{llllll}69-S E P-85 & 2444 & 252 & 0.178 & 5.394 & 128.537\end{array}$

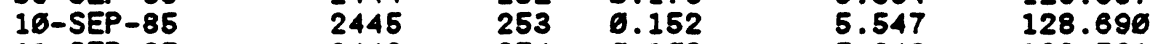

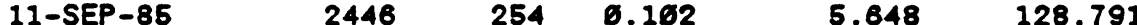

$\begin{array}{llllll}13-S E P-85 & 2448 & 256 & \mathbf{6} .279 & 5.928 & 129.671\end{array}$

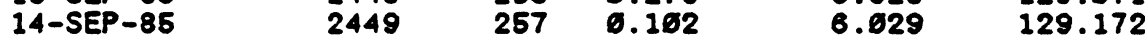

$\begin{array}{llllll}16-S E P-85 & 2451 & 259 & 0.676 & 6.165 & 129.249\end{array}$

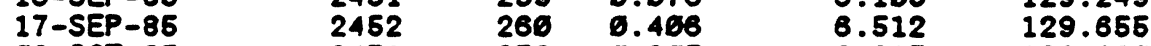

$\begin{array}{llllll}68-0 C T-85 & 2471 & 279 & 0.365 & 6.817 & 129.960\end{array}$

$\begin{array}{llllll}67-O C T-85 & 2472 & 286 & 6.635 & 7.452 & 136.595\end{array}$

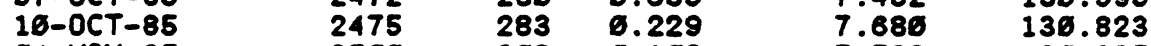

$\begin{array}{llllll}64-N O V-85 & 2508 & 368 & 6.162 & 7.782 & 130.925\end{array}$

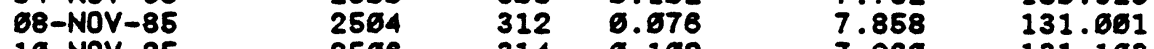

$\begin{array}{llllll}16-N O V-85 & 2566 & 314 & 6.162 & 7.966 & 131.163\end{array}$

$\begin{array}{llllll}15-N O V-85 & 2511 & 319 & \mathbf{6 . 4 3 2} & \mathbf{8 . 3 9 1} & 131.535\end{array}$

$\begin{array}{llllll}17-N O V-85 & 2513 & 321 & 6.279 & 8.671 & 131.814\end{array}$

$\begin{array}{llllll}19-N O V-85 & 2515 & 323 & 6.336 & 9.661 & 132.144\end{array}$

$\begin{array}{lllrrr}26-N O V-85 & 2516 & 324 & 0.127 & 9.128 & 132.271\end{array}$

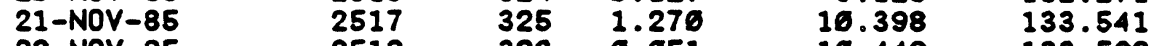

$\begin{array}{llllll}22-N O V-85 & 2518 & 326 & 0.651 & 10.449 & 133.592\end{array}$

$\begin{array}{llllll}25-N O V-85 & 2521 & 329 & 6.625 & 16.474 & 133.617\end{array}$

$\begin{array}{llllll}27-N O V-85 & 2523 & 331 & 0.263 & 10.677 & 133.821\end{array}$

$\begin{array}{llllll}29-N O V-85 & 2525 & 333 & 0.162 & 16.779 & 133.922\end{array}$

$\begin{array}{llllll}36-N O V-85 & 2526 & 334 & 0.651 & 10.836 & 133.973\end{array}$

$\begin{array}{llllll}61-D E C-85 & 2527 & 335 & 6.676 & 16.966 & 134.649\end{array}$

$\begin{array}{llllll}62-D E C-85 & 2528 & 336 & 0.864 & 11.770 & 134.913\end{array}$

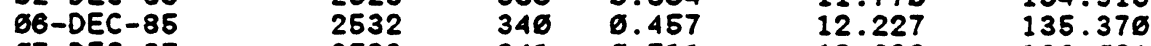

$\begin{array}{llllll}67-D E C-85 & 2533 & 341 & 6.711 & 12.938 & 136.881\end{array}$

$\begin{array}{llllll}24-D E C-85 & 2556 & 358 & 6.025 & 12.963 & 136.167\end{array}$

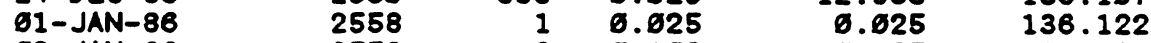

$\begin{array}{llllll}62-J A N-86 & 2559 & 3 & 0.162 & 0.127 & 136.223\end{array}$

$\begin{array}{llllll}04-J A N-86 & 2561 & 5 & 0.025 & 0.152 & 136.249\end{array}$

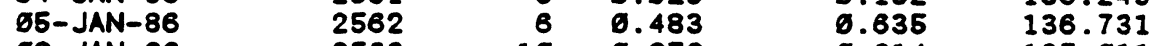

$\begin{array}{llllll}\text { 69-JAN-86 } & 2566 & 16 & 0.279 & 0.914 & 137.611\end{array}$

$\begin{array}{llllll}15-J A N-86 & 2572 & 16 & 6.152 & 1.067 & 137.163\end{array}$

$\begin{array}{llllll}16-J A N-86 & 2573 & 17 & 0.588 & 1.575 & 137.671\end{array}$

$1.893 \quad 137.990$

$\begin{array}{llllll}18-J A N-86 & 2575 & 18 & 0.178 & 1.981 & 138.878\end{array}$

$\begin{array}{llllll}22-J A N-86 & 2579 & 23 & 0.787 & 2.769 & 138.865\end{array}$

$\begin{array}{llllll}23-J A N-86 & 2586 & 23 & 6.152 & 2.921 & 139.818\end{array}$ 
TABLE A.2. (cont'd)

PRECIPITA.TION DATA FROM THE HANFORD METEOROLOGICAL STRTION 1979 TO JUNE 1987

\begin{tabular}{|c|c|c|c|c|c|}
\hline DATE & $\begin{array}{l}\text { DAYS SINCE } \\
\text { OI-JAN-79 }\end{array}$ & $\begin{array}{l}\text { DAY OF } \\
\text { YEAR }\end{array}$ & $\begin{array}{l}\text { PRECIP } \\
(\mathrm{CM})\end{array}$ & $\begin{array}{l}\text { CUMULATIVE } \\
\text { ANNUAL CM }\end{array}$ & $\begin{array}{l}\text { CUMULATIVE } \\
\text { TOTAL CM }\end{array}$ \\
\hline 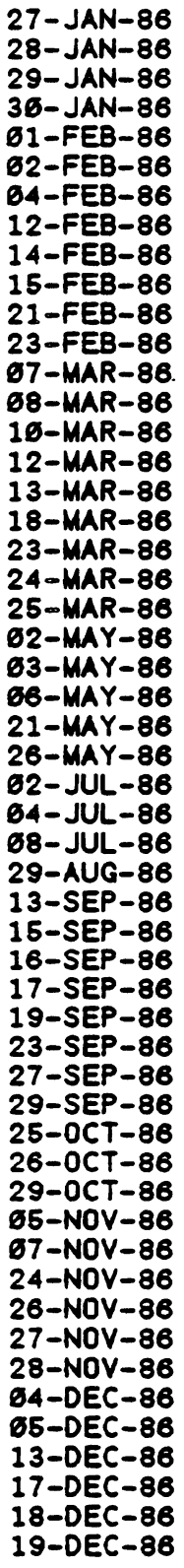 & $\begin{array}{l}2584 \\
2585 \\
2586 \\
2587 \\
2589 \\
2596 \\
2592 \\
2660 \\
2662 \\
2663 \\
2669 \\
2611 \\
2623 \\
2624 \\
2626 \\
2628 \\
2629 \\
2634 \\
2639 \\
2646 \\
2641 \\
2679 \\
2686 \\
2683 \\
2698 \\
2763 \\
2746 \\
2742 \\
2746 \\
2798 \\
2813 \\
2815 \\
2816 \\
2817 \\
2819 \\
2823 \\
2827 \\
2829 \\
2855 \\
2856 \\
2859 \\
2866 \\
2868 \\
2885 \\
2887 \\
2888 \\
2889 \\
2895 \\
2898 \\
2964 \\
2968 \\
2969 \\
2916\end{array}$ & $\begin{array}{l}27 \\
29 \\
36 \\
31 \\
32 \\
33 \\
36 \\
43 \\
46 \\
46 \\
53 \\
54 \\
66 \\
68 \\
69 \\
71 \\
73 \\
78 \\
83 \\
83 \\
85 \\
123 \\
123 \\
126 \\
141 \\
147 \\
184 \\
185 \\
189 \\
241 \\
257 \\
259 \\
259 \\
261 \\
263 \\
267 \\
271 \\
272 \\
299 \\
386 \\
363 \\
316 \\
311 \\
328 \\
331 \\
332 \\
333 \\
339 \\
346 \\
348 \\
351 \\
353 \\
353\end{array}$ & 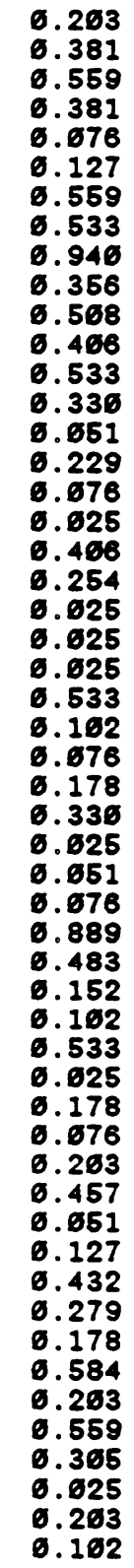 & $\begin{array}{r}3.124 \\
3.565 \\
4.864 \\
4.445 \\
4.521 \\
4.648 \\
5.267 \\
5.746 \\
6.686 \\
7.636 \\
7.544 \\
7.956 \\
8.484 \\
8.814 \\
8.865 \\
9.693 \\
9.169 \\
9.195 \\
9.661 \\
9.855 \\
9.881 \\
9.966 \\
9.931 \\
16.465 \\
16.566 \\
16.643 \\
16.826 \\
11.151 \\
11.176 \\
11.227 \\
11.363 \\
12.192 \\
12.675 \\
12.827 \\
12.929 \\
13.462 \\
13.487 \\
13.665 \\
13.741 \\
13.945 \\
14.462 \\
14.453 \\
14.580 \\
15.811 \\
15.291 \\
15.469 \\
16.653 \\
16.256 \\
16.815 \\
17.120 \\
17.145 \\
17.348 \\
17.456\end{array}$ & $\begin{array}{l}139.221 \\
139.662 \\
146.161 \\
146.542 \\
146.618 \\
146.745 \\
141.364 \\
141.837 \\
142.777 \\
143.132 \\
143.646 \\
144.647 \\
144.586 \\
144.916 \\
144.961 \\
145.196 \\
145.266 \\
145.291 \\
145.698 \\
145.952 \\
145.977 \\
146.063 \\
146.628 \\
146.561 \\
146.663 \\
146.739 \\
146.917 \\
147.247 \\
147.273 \\
147.323 \\
147.466 \\
148.289 \\
148.771 \\
148.924 \\
149.625 \\
149.559 \\
149.584 \\
149.762 \\
149.838 \\
156.861 \\
156.498 \\
156.549 \\
156.676 \\
151.168 \\
151.387 \\
151.565 \\
152.149 \\
152.353 \\
152.911 \\
153.216 \\
153.242 \\
153.445 \\
153.546\end{array}$ \\
\hline
\end{tabular}


TABLE A.2. (cont'd)

PRECIPITATION DATA FROM THE HANFORD METEOROLOGICAL STATION 1979 TO JUNE 1987

\begin{tabular}{|c|c|c|c|c|c|}
\hline DATE & $\begin{array}{l}\text { DAYS SINCE } \\
\text { פI-JAN-79 }\end{array}$ & $\begin{array}{l}\text { DAY OF } \\
\text { YEAR }\end{array}$ & $\begin{array}{l}\text { PRECIP } \\
(\mathrm{CM})\end{array}$ & $\begin{array}{l}\text { CUMULATIVE } \\
\text { ANNUAL CM }\end{array}$ & $\begin{array}{l}\text { CUMULATIVE } \\
\text { TOTAL CM }\end{array}$ \\
\hline 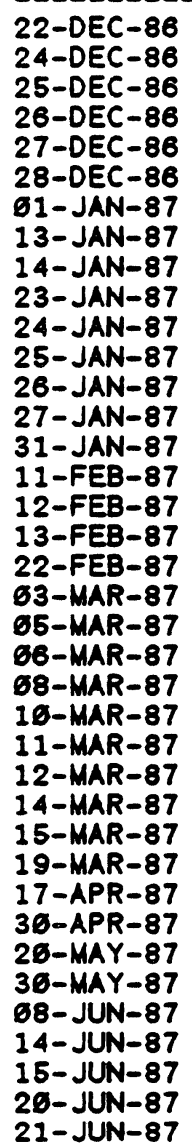 & $\begin{array}{l}2913 \\
2915 \\
2916 \\
2917 \\
2918 \\
2919 \\
2923 \\
2935 \\
2936 \\
2945 \\
2946 \\
2947 \\
2948 \\
2949 \\
2953 \\
2964 \\
2965 \\
2966 \\
2975 \\
2984 \\
2986 \\
2987 \\
2989 \\
2991 \\
2992 \\
2993 \\
2995 \\
2996 \\
3686 \\
3629 \\
3642 \\
3682 \\
3672 \\
3681 \\
3687 \\
3688 \\
3993 \\
3694\end{array}$ & $\begin{array}{r}357 \\
358 \\
366 \\
366 \\
362 \\
363 \\
1 \\
13 \\
14 \\
23 \\
24 \\
25 \\
26 \\
27 \\
31 \\
42 \\
43 \\
44 \\
53 \\
62 \\
64 \\
65 \\
67 \\
69 \\
76 \\
71 \\
73 \\
74 \\
78 \\
167 \\
126 \\
146 \\
156 \\
159 \\
165 \\
166 \\
171 \\
172\end{array}$ & 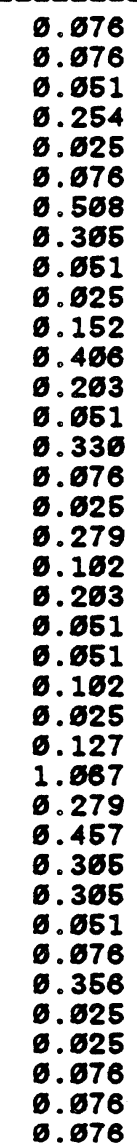 & $\begin{array}{r}17.526 \\
17.662 \\
17.653 \\
17.967 \\
17.932 \\
18.669 \\
6.568 \\
6.813 \\
6.864 \\
6.889 \\
1.841 \\
1.448 \\
1.651 \\
1.762 \\
2.632 \\
2.168 \\
2.134 \\
2.413 \\
2.515 \\
2.718 \\
2.769 \\
2.819 \\
2.921 \\
2.946 \\
3.673 \\
4.146 \\
4.426 \\
4.877 \\
5.182 \\
5.486 \\
5.537 \\
5.613 \\
5.969 \\
5.994 \\
6.026 \\
6.696 \\
6.172 \\
6.248\end{array}$ & 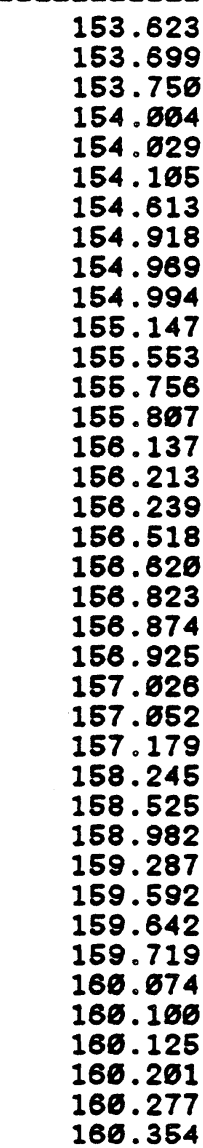 \\
\hline
\end{tabular}


TABLE A.3. Drainage from the South Caisson

SOUTH CASSION DRAINAGE

\begin{tabular}{|c|c|c|c|c|c|c|c|}
\hline $\begin{array}{l}\text { NOTE } \\
1 / 2 / 86\end{array}$ & DATE & $\begin{array}{l}\text { DAY OF } \\
\text { YEAR }\end{array}$ & $\begin{array}{l}\text { DAYS SINCE } \\
\text { פ1-JAN-81 }\end{array}$ & $\begin{array}{l}\text { DRAINAGE } \\
(g)\end{array}$ & $\begin{array}{l}\text { EQUIVALENT } \\
\text { WATER (CM) }\end{array}$ & $\begin{array}{l}\text { CUMULATIVE CM } \\
\text { ANNUAL DRAINAGE }\end{array}$ & $\begin{array}{l}\text { CUMULATIVE } \\
\text { DRAINAGE (cm) }\end{array}$ \\
\hline & 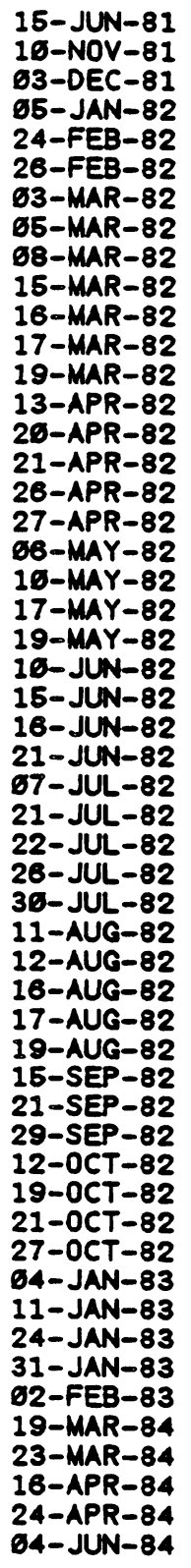 & $\begin{array}{r}166 \\
314 \\
337 \\
5 \\
55 \\
57 \\
62 \\
64 \\
67 \\
74 \\
75 \\
76 \\
78 \\
163 \\
116 \\
111 \\
116 \\
117 \\
126 \\
136 \\
137 \\
139 \\
161 \\
166 \\
167 \\
172 \\
188 \\
262 \\
263 \\
267 \\
211 \\
223 \\
224 \\
228 \\
229 \\
231 \\
258 \\
264 \\
272 \\
285 \\
292 \\
294 \\
366 \\
11 \\
11 \\
24 \\
31 \\
33 \\
79 \\
83 \\
167 \\
115 \\
156\end{array}$ & $\begin{array}{l}166 \\
314 \\
337 \\
376 \\
426 \\
422 \\
427 \\
429 \\
432 \\
439 \\
446 \\
441 \\
443 \\
468 \\
475 \\
476 \\
481 \\
482 \\
491 \\
495 \\
562 \\
564 \\
526 \\
531 \\
532 \\
537 \\
553 \\
567 \\
568 \\
572 \\
576 \\
588 \\
589 \\
593 \\
594 \\
596 \\
623 \\
629 \\
637 \\
656 \\
657 \\
659 \\
665 \\
734 \\
741 \\
754 \\
761 \\
763 \\
1174 \\
1178 \\
1262 \\
1216 \\
1251\end{array}$ & $\begin{array}{r}1260 \\
146 \\
64696 \\
58459 \\
21467 \\
36727 \\
16667 \\
2871 \\
6616 \\
6636 \\
7124 \\
3748 \\
2627 \\
2591 \\
4246 \\
19392 \\
4129 \\
2384 \\
7163 \\
4682 \\
6387 \\
2492 \\
11436 \\
5314 \\
3437 \\
3998 \\
6444 \\
16436 \\
3649 \\
3965 \\
3671 \\
5819 \\
2981 \\
2971 \\
1261 \\
1946 \\
11876 \\
6611 \\
6666 \\
7643 \\
7665 \\
3632 \\
4561 \\
18158 \\
9326 \\
9898 \\
7146 \\
6575 \\
79516 \\
173768 \\
43596 \\
7785 \\
82476\end{array}$ & 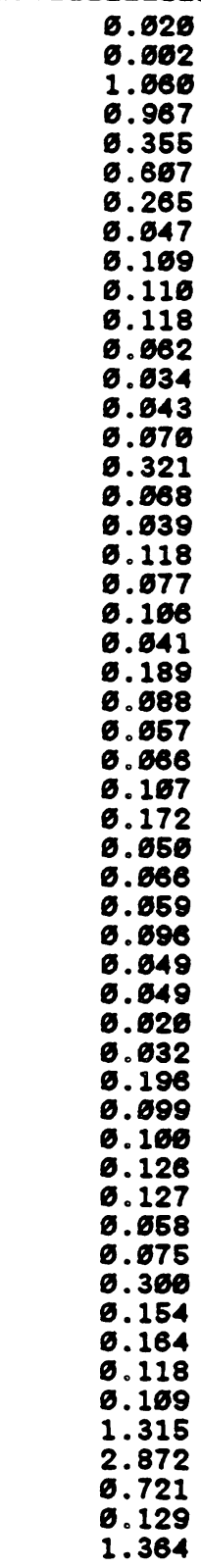 & $\begin{array}{l}6.626 \\
6.622 \\
1.882 \\
6.967 \\
1.322 \\
1.929 \\
2.194 \\
2.241 \\
2.356 \\
2.466 \\
2.578 \\
2.646 \\
2.673 \\
2.716 \\
2.786 \\
3.167 \\
3.175 \\
3.215 \\
3.333 \\
3.416 \\
3.516 \\
3.557 \\
3.746 \\
3.834 \\
3.891 \\
3.957 \\
4.664 \\
4.236 \\
4.286 \\
4.352 \\
4.411 \\
4.567 \\
4.557 \\
4.666 \\
4.626 \\
4.658 \\
4.854 \\
4.953 \\
5.654 \\
5.186 \\
5.367 \\
5.365 \\
5.441 \\
6.366 \\
6.454 \\
6.618 \\
6.736 \\
6.845 \\
1.315 \\
4.187 \\
4.968 \\
5.607\end{array}$ & $\begin{array}{l}6.628 \\
6.622 \\
1.682 \\
2.648 \\
2.463 \\
3.611 \\
3.275 \\
3.323 \\
3.432 \\
3.542 \\
3.668 \\
3.722 \\
3.755 \\
3.798 \\
3.868 \\
4.189 \\
4.257 \\
4.296 \\
4.415 \\
4.492 \\
4.598 \\
4.639 \\
4.828 \\
4.916 \\
4.973 \\
5.639 \\
5.145 \\
5.318 \\
5.368 \\
5.434 \\
5.493 \\
5.589 \\
5.638 \\
5.688 \\
5.767 \\
5.746 \\
5.936 \\
6.835 \\
6.136 \\
6.262 \\
6.389 \\
6.447 \\
6.522 \\
6.823 \\
6.977 \\
7.141 \\
7.259 \\
7.367 \\
8.682 \\
11.554 \\
12.275 \\
12.464 \\
13.768\end{array}$ \\
\hline
\end{tabular}

THE COLUMN AREA IS 60478 SQUARE CM. 
TABLE A.3. (contd)

SOUTH CASSION DRAINAGE

\begin{tabular}{|c|c|c|c|c|c|c|c|}
\hline $\begin{array}{l}\text { NOTE } \\
1 / 2 / 86\end{array}$ & DATE & $\begin{array}{l}\text { DAY OF } \\
\text { YEAR }\end{array}$ & $\begin{array}{l}\text { DAYS SINCE } \\
\text { O1-JAN-81 }\end{array}$ & $\begin{array}{l}\text { DRAINAGE } \\
(g)\end{array}$ & $\begin{array}{l}\text { EQUIVALENT } \\
\text { WATER (CM) }\end{array}$ & $\begin{array}{l}\text { CUMULATIVE CM } \\
\text { ANNUAL DRAINAGE }\end{array}$ & $\begin{array}{l}\text { CUMULATIVE } \\
\text { DRAINAGE (cm) }\end{array}$ \\
\hline & $\begin{array}{l}17-J U L-84 \\
\text { 66-AUG-84 } \\
19-N O V-84 \\
12-D E C-84 \\
15-F E B-85 \\
18-A P R-85 \\
\text { 63-MAY-85 } \\
16-M A Y-85 \\
36-M A Y-85 \\
11-J U N-85 \\
27-J U N-85 \\
69-J U L-85 \\
23-J U L-85 \\
13-A U G-85 \\
29-A U G-85 \\
69-S E P-85 \\
23-S E P-85 \\
67-O C T-85 \\
14-O C T-85 \\
61-N O V-85 \\
26-N O V-85 \\
\text { 63-DEC-85 } \\
26-D E C-85 \\
26-D E C-85 \\
36-D E C-85 \\
15-J A N-86 \\
28-J A N-86 \\
13-F E B-86 \\
26-F E B-86 \\
14-M A R-86 \\
25-M A R-86 \\
\text { 67-APR-86 } \\
24-A P R-86 \\
66-M A Y-86 \\
21-M A Y-86 \\
28-M A Y-86 \\
62-J U N-86 \\
11-J U N-86 \\
17-J U N-86 \\
36-J U N-86 \\
16-J U L-86 \\
18-J U L-86 \\
36-J U L-86 \\
13-A U G-86 \\
25-A U G-86 \\
69-S E P-86 \\
63-O C T-86 \\
18-O C T-86 \\
29-0 C T-86 \\
13-N O V-86 \\
64-D E C-86 \\
16-D E C-86 \\
29-D E C-86\end{array}$ & $\begin{array}{r}199 \\
219 \\
324 \\
347 \\
46 \\
168 \\
123 \\
136 \\
156 \\
162 \\
178 \\
198 \\
284 \\
225 \\
241 \\
252 \\
266 \\
286 \\
287 \\
365 \\
324 \\
337 \\
354 \\
360 \\
364 \\
15 \\
28 \\
44 \\
57 \\
73 \\
84 \\
97 \\
114 \\
126 \\
141 \\
148 \\
153 \\
162 \\
168 \\
181 \\
191 \\
199 \\
211 \\
225 \\
237 \\
252 \\
276 \\
283 \\
362 \\
317 \\
338 \\
356 \\
363\end{array}$ & $\begin{array}{l}1294 \\
1314 \\
1419 \\
1442 \\
1567 \\
1569 \\
1584 \\
1597 \\
1611 \\
1623 \\
1639 \\
1651 \\
1665 \\
1686 \\
1762 \\
1713 \\
1727 \\
1741 \\
1748 \\
1766 \\
1785 \\
1798 \\
1815 \\
1821 \\
1825 \\
1841 \\
1854 \\
1876 \\
1883 \\
1899 \\
1916 \\
1923 \\
1946 \\
1952 \\
1967 \\
1974 \\
1979 \\
1988 \\
1994 \\
2667 \\
2617 \\
2625 \\
2637 \\
2651 \\
2663 \\
2678 \\
2162 \\
2169 \\
2128 \\
2143 \\
2164 \\
2176 \\
2189\end{array}$ & 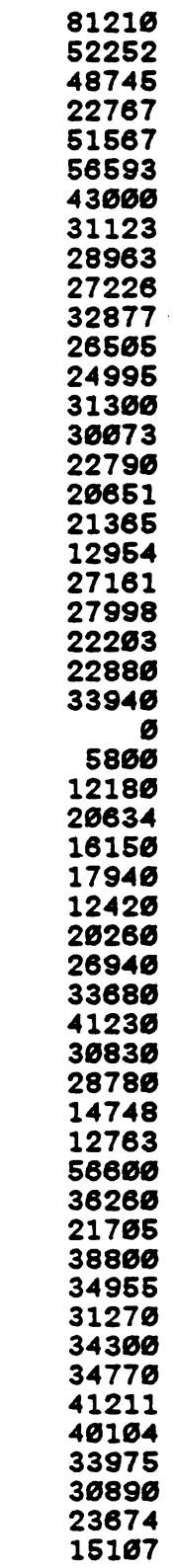 & 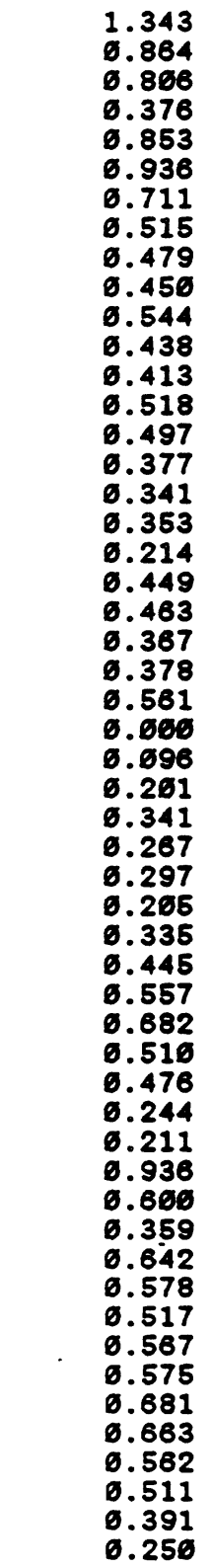 & $\begin{array}{r}7.743 \\
8.667 \\
9.413 \\
9.789 \\
8.853 \\
1.788 \\
2.499 \\
3.614 \\
3.493 \\
3.943 \\
4.487 \\
4.925 \\
5.338 \\
5.856 \\
6.353 \\
6.736 \\
7.671 \\
7.425 \\
7.639 \\
8.688 \\
8.551 \\
8.918 \\
9.296 \\
9.858 \\
9.858 \\
9.896 \\
6.297 \\
9.638 \\
9.966 \\
1.262 \\
1.468 \\
1.743 \\
2.188 \\
2.745 \\
3.427 \\
3.936 \\
4.412 \\
4.656 \\
4.867 \\
5.863 \\
6.463 \\
6.761 \\
7.463 \\
7.981 \\
8.498 \\
9.865 \\
9.646 \\
16.322 \\
16.985 \\
11.546 \\
12.857 \\
12.449 \\
12.698\end{array}$ & $\begin{array}{l}15.116 \\
15.974 \\
16.786 \\
17.157 \\
18.61 \varnothing \\
18.945 \\
19.656 \\
2 \varnothing .171 \\
2 \varnothing .650 \\
21.166 \\
21.644 \\
22.682 \\
22.495 \\
23.613 \\
23.51 \varnothing \\
23.887 \\
24.228 \\
24.582 \\
24.796 \\
25.245 \\
25.768 \\
26.675 \\
26.453 \\
27.614 \\
27.814 \\
27.116 \\
27.312 \\
27.653 \\
27.92 \varnothing \\
28.217 \\
28.422 \\
28.757 \\
29.262 \\
29.759 \\
36.441 \\
36.951 \\
31.427 \\
31.671 \\
31.882 \\
32.817 \\
33.417 \\
33.776 \\
34.417 \\
34.995 \\
35.513 \\
36.886 \\
36.655 \\
37.336 \\
37.999 \\
38.561 \\
39.672 \\
39.463 \\
39.713\end{array}$ \\
\hline
\end{tabular}

THE COLUMN AREA IS 60478 SQUARE CM. 
TABLE A.3. (contd)

SOUTH CASSION DRRINAGE

\begin{tabular}{|c|c|c|c|c|c|c|c|}
\hline $\begin{array}{l}\text { NOTE } \\
1 / 2 / 86\end{array}$ & DATE & $\begin{array}{l}\text { DAY OF } \\
\text { YEAR }\end{array}$ & $\begin{array}{l}\text { DAYS SINCE } \\
\text { G1-JAN-81 }\end{array}$ & $\begin{array}{l}\text { DRAINAGE } \\
(g)\end{array}$ & $\begin{array}{l}\text { EQUIVALENT } \\
\text { WATER (CM) }\end{array}$ & $\begin{array}{l}\text { CUMULATIVE CM } \\
\text { ANNUAL DRAINAGE }\end{array}$ & $\begin{array}{l}\text { CUMULATIVE } \\
\text { DRAINAGE }(\mathrm{cm})\end{array}$ \\
\hline & $\begin{array}{l}13-J A N-87 \\
36-J A N-87 \\
11-F E B-87 \\
24-F E B-87 \\
18-M A R-87 \\
31-M A R-87 \\
26-A P R-87 \\
\text { E5-MAY }-87 \\
26-M A Y-87 \\
17-J U N-87\end{array}$ & $\begin{array}{r}13 \\
36 \\
42 \\
55 \\
77 \\
96 \\
116 \\
125 \\
146 \\
158\end{array}$ & $\begin{array}{l}2204 \\
2221 \\
2233 \\
2246 \\
2268 \\
2281 \\
2361 \\
2316 \\
2337 \\
2349\end{array}$ & $\begin{array}{l}15468 \\
21765 \\
15516 \\
18637 \\
26961 \\
19860 \\
22816 \\
17516 \\
18450 \\
19360\end{array}$ & $\begin{array}{l}0.256 \\
6.359 \\
6.256 \\
6.368 \\
6.346 \\
0.328 \\
6.377 \\
6.296 \\
6.365 \\
6.319\end{array}$ & $\begin{array}{l}\sigma .256 \\
6.615 \\
6.871 \\
1.179 \\
1.525 \\
1.853 \\
2.236 \\
2.526 \\
2.825 \\
3.144\end{array}$ & $\begin{array}{l}39.969 \\
46.328 \\
46.584 \\
46.892 \\
41.238 \\
41.566 \\
41.943 \\
42.233 \\
42.538 \\
42.857\end{array}$ \\
\hline
\end{tabular}

THE COLUMN AREA IS 60478 SQUARE CM. 
TABLE A.4. Drainage from the North Weighing Lysimeter

DRAINAGE FROM THE NORTH WEIGHING LYSIMETER SINCE 1984

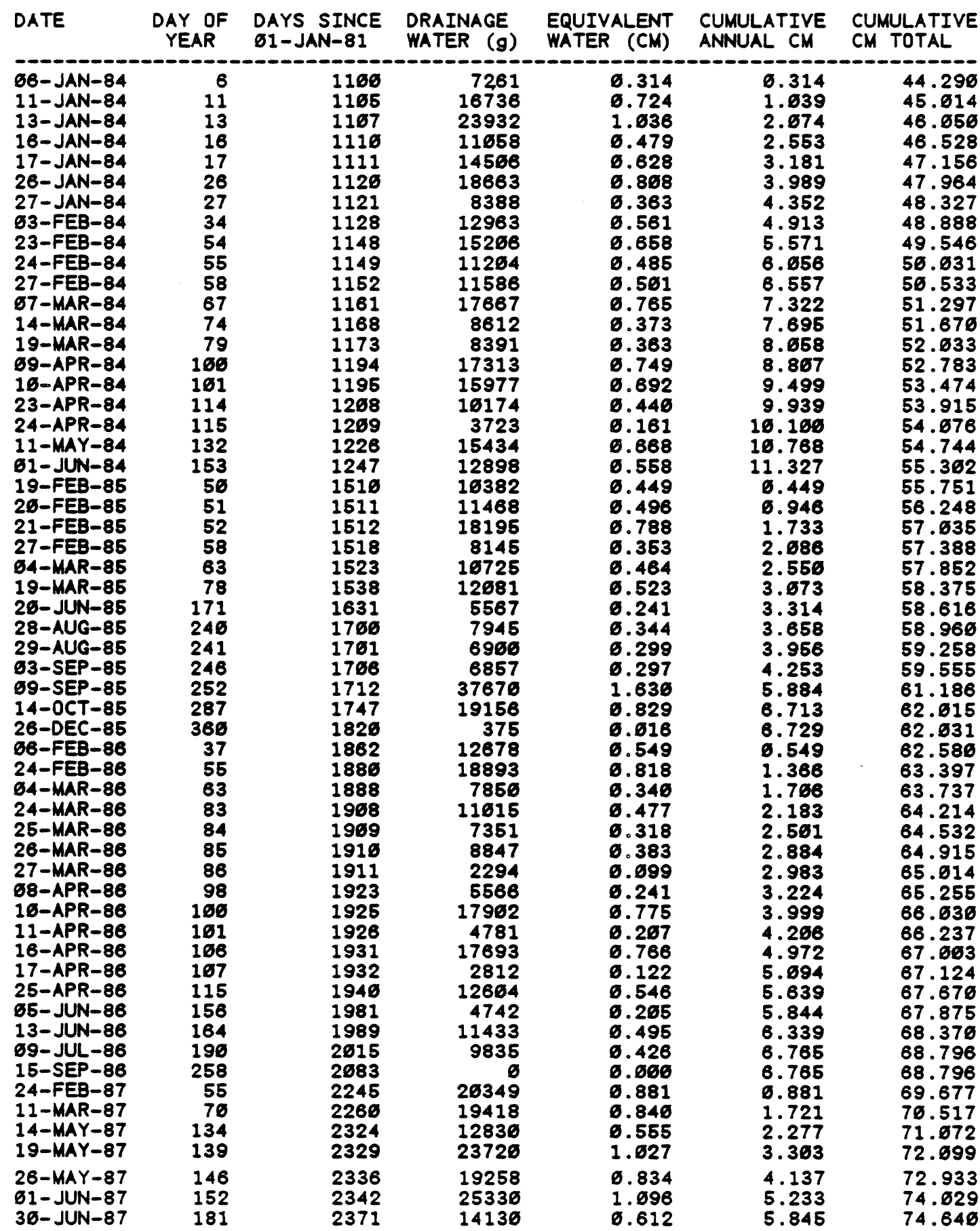


TABLE A.5. Drainage from the South Weighing Lysimeter

DRAINAGE FROM THE SOUTH WEIGHING LYSIMETER SINCE 1984

\begin{tabular}{|c|c|c|c|c|c|c|}
\hline DATE & $\begin{array}{l}\text { DAY OF } \\
\text { YEAR }\end{array}$ & $\begin{array}{l}\text { DAYS SINCE } \\
\text { E1-JAN-81 }\end{array}$ & $\begin{array}{l}\text { WATER RE } \\
\text { MOVED ( }(g)\end{array}$ & $\begin{array}{l}\text { EQUIVALENT } \\
\text { WATER (CM) }\end{array}$ & $\begin{array}{l}\text { CUMULATIVE } \\
\text { ANNUAL CM }\end{array}$ & $\begin{array}{l}\text { CUMULATIVE } \\
\text { CM TOTAL }\end{array}$ \\
\hline $\begin{array}{l}\text { 66-JAN-84 } \\
\text { 69-JAN-84 } \\
16-J A N-84 \\
11-J A N-84 \\
12-J A N-84 \\
23-F E B-84 \\
16-A P R-84 \\
12-A P R-84 \\
18-A P R-84 \\
\text { g1-JUN-84 } \\
12-D E C-84 \\
26-F E B-85 \\
21-F E B-85 \\
26-J U N-86 \\
\text { 62-AUG-85 } \\
14-0 C T-85 \\
26-D E C-86 \\
24-J A N-86 \\
18-F E B-86 \\
24-F E B-86 \\
\text { g4-MAR-86 } \\
25-M A R-86 \\
26-M A R-86 \\
27-M A R-86 \\
\text { g8-APR-86 } \\
16-A P R-86 \\
16-A P R-86 \\
\text { E5-JUN-86 } \\
13-J U N-86 \\
\text { E9-JUL-86 } \\
15-S E P-86 \\
19-D E C-86\end{array}$ & $\begin{array}{r}6 \\
9 \\
16 \\
11 \\
12 \\
54 \\
161 \\
163 \\
169 \\
153 \\
347 \\
51 \\
52 \\
171 \\
214 \\
287 \\
366 \\
24 \\
49 \\
55 \\
63 \\
84 \\
85 \\
86 \\
98 \\
166 \\
166 \\
156 \\
164 \\
196 \\
258 \\
353\end{array}$ & $\begin{array}{l}1166 \\
1163 \\
1164 \\
1165 \\
1166 \\
1148 \\
1195 \\
1197 \\
1263 \\
1247 \\
1441 \\
1511 \\
1512 \\
1631 \\
1674 \\
1747 \\
1826 \\
1849 \\
1874 \\
1886 \\
1888 \\
1969 \\
1916 \\
1911 \\
1923 \\
1925 \\
1931 \\
1981 \\
1989 \\
2615 \\
2683 \\
2178\end{array}$ & $\begin{array}{r}14656 \\
13887 \\
18163 \\
16733 \\
14464 \\
28564 \\
18493 \\
18831 \\
18558 \\
11986 \\
14916 \\
5662 \\
17658 \\
11296 \\
1867 \\
18656 \\
14712 \\
3332 \\
9573 \\
35363 \\
15566 \\
24866 \\
28314 \\
23668 \\
13226 \\
27691 \\
4682 \\
11617 \\
12566 \\
4528 \\
6 \\
6\end{array}$ & 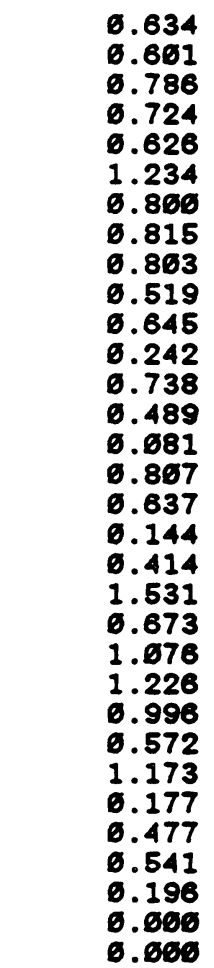 & $\begin{array}{l}6.634 \\
1.235 \\
2.621 \\
2.746 \\
3.372 \\
4.665 \\
5.466 \\
6.221 \\
7.624 \\
7.543 \\
8.188 \\
6.242 \\
6.981 \\
1.469 \\
1.556 \\
2.357 \\
2.994 \\
9.144 \\
6.559 \\
2.689 \\
2.762 \\
3.838 \\
5.664 \\
6.666 \\
6.632 \\
7.865 \\
7.981 \\
8.458 \\
8.999 \\
9.195 \\
9.195\end{array}$ & $\begin{array}{l}10.654 \\
10.655 \\
11.441 \\
12.165 \\
12.791 \\
14.625 \\
14.826 \\
15.641 \\
16.444 \\
16.963 \\
17.668 \\
17.856 \\
18.589 \\
19.877 \\
19.158 \\
19.965 \\
26.662 \\
28.746 \\
21.161 \\
22.691 \\
23.364 \\
24.441 \\
25.666 \\
26.662 \\
27.234 \\
28.467 \\
28.583 \\
29.668 \\
29.661 \\
29.797 \\
29.797 \\
29.797\end{array}$ \\
\hline
\end{tabular}




\section{$\underline{\text { DISTRIBUTION }}$}

No. of

Copies

OFFSITE

30 DOE Technical Information Center

6 DOE Office of Civilian

Radioactive Waste Management

Forrestal Building

Washington, DC 20585

ATTN: L. H. Barrett, RW-33

C. R. Cooley, RW-40

J. R. Hilley, RW-30

S. H. Kale, RW-20

D. E. Shelor, RW-32

R. Stein, RW-23

4 DOE Office of Defense Waste \& GTN

Washington, DC 20545

ATTN: T. C. Chee, DP-123

K. A. Chorey, DP-123

G. H. Daly, DP-124

J. E. Lytle, DP-12

4 DOE Office of Remedial Action GTN

\& Waste Technology

Washington, DC 20545

ATTN: J. A. Coleman, NE-24

T. W. McIntosh, NE-24

W. R. Voight, NE-20

H. F. Walter, NE-24

3 DOE Idaho Operations Office

550 Second Street

Idaho Fal1s, ID 83401

ATTN: J. P. Hamric

S. T. Hinschberger

J. L. Lyle
No. of

Copies

W. J. Brumley

DOE Savannah River Operations Office

P.0. Box A

Aiken, SC 29801

F. T. Fong

DOE San Francisco Operations

1333 Broadway

Oakland, CA 94612

M. R. Jugan

DOE Oak Ridge Operations Office P.0. Box E

Oak Ridge, TN 37830

E. Maestas

DOE West Valley Project Office P.0. Box 191

West Valley, NY 14171

J. M. McGough

DOE Albuquerque Operations Office

P.0. Box 5400

Albuquerque, NM 87185

C. S. Abrams

Argonne National Laboratory

P.0. Box 2528

Idaho Falls, ID 83401

Battelle Memorial Institute

Project Management Division 505 King Avenue

Columbus, $\mathrm{OH} 43201$

ATTN: W. A. Carbeiner

W. S. Madia

Technical Library 
J. R. Berreth

Westinghouse Idaho Nuclear

Co., Inc.

P.0. Box 4000

Idaho Falls, ID 83401

W. Brewer

Office of High-Level Nuclear Waste Management

Washington State Department of Ecology

Mail Stop PV-11

Olympia, WA 98504

G. S. Campbell

Agronomy Department

Washington State University

Pullman, WA 99164

A. T. Clark

Division of Fuel Material Safety

Nuclear Regulatory Commission

Washington, DC 20555

G. A. Dinwiddie

U.S. Geological Survey

12201 Sunrise Valley Drive

Reston, VA 22092

E. I. du Pont de Nemours Company

Savannah River Laboratory

Aiken, SC 29801

ATTN: R. G. Baxter

M. D. Boersma

J. G. Glasscock

J. R. Knight

M. J. Plodinec

C. T. Randall

J. Fischer

Low-Level Radioactive Waste Program

U.S. Geological Survey

Water Resources Division

12201 Sunrise Valley Drive

Reston, VA 22092
L. Frank

Department of Energy

625 Marion Street, N.E.

Salem, OR 97310

P. G. Hagan

Joint Integration office

Carlmont Executive 1

4308 Carlisle N.E.

Albuquerque, NM 87107

T. E. Hakonson

Los Alamos National Laboratory

P.0. Box 1663

Los Alamos, NM 87545

D. Hillel

Department of Plant and Soil

Science

12A Stockbridge Hall

University of Massachusetts

Amherst, MA 01003

E. A. Jennrich

EG\&G Idaho

P.0. Box 1625

Idaho Falls, ID 83415

W. A. Jury

Department of Soils

University of California at Riverside

Riverside, CA 92502

D. A. Knecht

Westinghouse Idaho Nuclear Company

P.0. Box 4000

Idaho Falls ID 83403

S. Meyers

Environmental Protection Agency

Office of Radiation Programs (ANR-458)

401 M Street S.W.

Washington, DC 20460 
T. J. Nicholson

U.S. Nuclear Regulatory Commission

Div. of Engineering Safety

MS NL-005

Washington, DC 20555

J. W. Nyhan

Los Alamos National Laboratory

P.0. Box 1663

Los Alamos, NM 87545

Oak Ridge National Laboratory

P.0. Box $Y$

Oak Ridge, TN 37830

ATTN: J. 0. Blomeke

W. D. Burch

R. T. Jubin

L. J. Mezga

D. T. Oakley, MS 619

Los Alamos Scientific Laboratory

P.0. Box 1663

Los Alamos, NM 87544

E. O'Donnell

Earth Sciences Branch

Division of Health, Siting and Waste Management Research

U.S. Nuclear Regulatory Commission

Washington, DC 20555

L. D. Ramspott

Lawrence Livermore National Laboratory

University of California

P.0. Box 808

Livermore, CA 94550

J. Rensel

High-Level Waste Management

Washington State Department of Ecology

Mail Stop Pu II

Olympia, WA 98504
E. M. Romney

Laboratory of Biomedical and Environmental Sciences

University of California at Los Angeles

Los Angeles, CA 90024

Sandia Laboratories

P.0. Box 5800

Albuquerque, NM 87185

ATTN: R. W. Lynch

Technical Library

R. Shaw

Electric Power Research Institute

3412 Hillview Avenue

P.0. Box 10412

Palo Alto, CA 94304

M. J. Steindler

Argonne National Laboratory

9700 South Cass Avenue

Argonne, IL 60439

V. Stello

Office of the Executive Director for Operations

Mail Station 6209

Nuclear Regulatory Commission Washington, DC 20555

D. Stephens

Dept. of Geosciences

New Mexico Institute of Mining and Technology

Socorro, NM 87801

S. Tyler

Desert Research Institute

P.0. Box 60220

Reno, NV 89506

E. P. Weeks

U.S. Geological Survey

Federal Center Mail Stop 413

Denver, CO 80225 
No. of

Copies

West Valley Nuclear Services Company

P.0. Box 191

West Valley, NY 14171

ATTN: C. C. Chapman

J. C. Cwynar

J. E. Krauss

S. J. Marchette

J. M. Pope

J. L. White, Chairman

Energy Research \& Development Authority

Empire State Plaza

Albany, NY 12223

P. J. Wierenga

Dept. of Soil Science

New Mexico State University

Las Cruces, NM 88004

I. J. Winograd

U.S. Geological Survey

National Center - Mail Stop 432

Reston, VA 22092

\section{ONSITE}

10 DOE Richland Operations Office

E. A. Bracken

G. J. Bracken

C. E. Collantes

C. R. DeLannoy

J. R. Hunter

0 . L. Olson

J. M. Peterson

G. W. Rosenwald

M. W. Shupe

J. J. Sutey
No of

Copies

20 Westinghouse Hanford Company

M. R. Adams

T. B. Bergman

J. W. Cammann

R. A. Carlson

C. DeFigh-Price

C. J. Geier

J. M. Henderson

J. 0 . Henrie

M. T. Jansky

D. S. Landeen

R. E. Lerch

H. E. McGuire

K. W. Owens

S. J. Phillips

J. F. Relyea

W. W. Schulz

J. L. Scott

N. R. Wing

D. D. Wodrich

R. D. Wojtasek

57 Pacific Northwest Laboratory

W. W. Ballard, Jr.

P. A. Beedlow

L. L. Cadwe 11

M. D. Campbe 11

J. W. Cary

J. L. Downs

D. W. Dragnich

M. J. Fayer

M. G. Foley

M. D. Freshley

H. D. Freeman

G. W. Gee (15)

S. M. Goodwin

M. J. Graham

J. M. Hales

P. C. Hays

P. R. Heller 
No. of

Copies

T. L. Jones

C. T. Kincaid

R. R. Kirkham

S. A. Kreml

G. V. Last

M. W. Ligotke

S. 0. Link

J. F. McBride

J. L. McElroy

D. H. Mitchell

E. Murphy
No. of

Copies

R. W. Nelson

L. E. Roger

C. S. Simmons

R. L. Skaggs

J. A. Stottlemyre

G. P. Streile

R. L. Treat

R. E. Wildung

Publishing Coordination (2)

Technical Report Files (5) 